COREF UNIVERSITY OF TOKYO

RELF Group

OEAPS (OPEN EUROPEAN ACADEMY OF

PUBLIC SCIENCES)

\title{
International Symposium on
}

Education, Psychology and

\section{Social Sciences}

\section{September, 282019}

$$
\text { Tokyo - Japan }
$$





\section{International Committees}

Adeeb Jarrah, United Arab Emirates University, United Arab Emirates Ahrar Husain, Jamia Millia Islamia, India

Alex Yao Tang, National Cheng Kung University, Taiwan

Ashish Pareek, Maharshi Dayanand Saraswati University, India

Atefeh Ferdosipour, Azad University, Iran

Azidah Abu Ziden, Universiti Sains Malaysia

Azilawati, Nanyang Technological University, Singapore

Aziz Bin Ahmad, University Malaysia Terengganu, Malaysia

B. Suresh Lal, Kakatiya University, India

Badar Alam Iqbal, Aligarh Muslim University, India

Bayram Akarsu, Erciyes University, Turkey

Bor-Tyng Wang, Feng Chia University, Taiwan

Brian Hunt, Mahidol University, Thailand

Cathine G. Scott, Morris College in Sumter, USA

Chen-Yi Lin, National Taichung University of Science and Technology, Taiwan

Chia-Hwan Chen, National Taipei University of Education, Taiwan

Chia-Ming Chang, National Chia-Yi University, Taiwan

Chib Datta Meghe, Institute of Management Studies, India

Chih-Wei Peng, Taipei Medical University and Hospital, Taiwan

Ching-Yi Tien, I-Shou University, Taiwan

Chi-Ying Chen, Asia University, Taiwan

Concepcion C. Libuit, City University of Pasay, Philippines

Darshan Kaur Narang, University of Rajasthan, India

Dharam Vir Mahajan, CCS University, India

Donald L. Amoroso, Auburn University at Montgomery, USA

Donghun Lee, Sungkyunkwan University, South Korea

Eddy K.W. Li, The Chinese University of Hong Kong, Hong Kong

Edward Hwang, Chung Hua University, Taiwan

Eric Santos Parilla, University of Asia and the Pacific, Philippines

Frank S.C. Tseng, National Kaohsiung First University of Science and Technology, Taiwan

Funda Varnaci Uzun, Aksaray University, Turkey

Hamzeh Dodeen, United Arab Emirates University, United Arab Emirates Intan Soliha Binti Ibrahim,

Universiti Malaysia Sabah, Malaysia

Irene Guatno Toribio, Philippine Christian University, Philippines

Jalil Safaei, University of Northern British Columbia, Canada

Jamie Halsall, University of Huddersfield, UK

Jeffrey Trambley, Musashino Gakuin University, Japan

Jian-Horng Chen, Chung Shan Medical University, Taiwan

John Christian S. Jardin, Palawan State University, Philippines

John Erinorio Perez, University of the Philippines Los Baños, Philippines Jonas Chao-Pen Yu, Takming

University of Science and Technology, Taiwan Joseph Lau, The University of Hong Kong, Hong Kong Joyce Zhou, Emporia State University, USA

Junaid M. Shaikh, Curtin University Sarawak Malaysia, Malaysia

Kaedsiri Jaroenwisan, Silpakorn Univesity, Thailand

Kanokphon Chantanarungpak, Srinakharinwirot University, Thailand Karen Miranda Fernandez, Imus Institute, Philippines

Karendra Devroop, University of South Africa, South Africa

Kyung Hee Kim, Mokpo National University, South Korea

Kim Sangho, Ritsumeikan Asia Pacific University, Japan

Deok Man Kim, Baekseok University, South Korea

Krishna Govender, AAA School of Advertising, South Africa 
Hsiao-Tseng Lin, Meiho University, Taiwan

Linda Oshita, University of Hwaii, USA

Margaret Sanapo, Ritsumeikan University, Japan

Maria Cristina M. De los Santos, Kyungdong University-Global Campus, South Korea

Marie Paz E. Morales, Philippine Normal University, Philippines

Mehryar Nooriafshar, University of Southern Queensland, Australia Michael Kao, Chang Gung University,

Taiwan

Micheal Kon, Aletheia University, Taiwan

Michelle M. Mukherjee, Queensland University of Technology, Australia Mindy Suzanne Andino,

Bloomsburg University, USA

Ming-Chang Chih, National Chung Hsing University, Taiwan

Mingchu Luo, Emporia State University, USA

Mohamad Hafis Amat Simin, University Sultan Zainal Abdin, Malaysia Mohamed Ahmed El Khouli, Sadat

Academy for Management Science, Egypt

Mohamed Hammad Hendy, Beni-Suef University, Egypt

N. S. Ravishankar, Axis Bank, India

Naim Uzun, Aksaray University, Turkey

Nezaket Memmedli, Azerbaijan National Academy of Sciences, Azerbaijan Ng Woon Lam, Nanyang

Technological University, Singapore

Nukshi Esther Imsong, Institution of Psychology Counselling and Educational Research, India

Obydullah Al Marjuk, Independent University, Bangladesh

Ozgul Keles, Aksaray University, Turkey

Prasong Tanpichai, Kasetsart University, Thailand

Ramayah Thurasamy, Universiti Sains Malaysia, Malaysia

Reem Abed Almotaleb Abuiyada, Dhofar University, Palestine

Ricky Ng, Vocational Training Council, Hong Kong

Ronald Griffin, Florida Agricultural \& Mechanical University, USA

Rotaru Ioan-Gheorghe, Timotheus Brethren Theological Insititute of Bucharest, Romania

Ruby Ann L. Ayo, Bicol University, Philippines

Sadiq Abdulwahed Ahmed Ismail, United Arab Emirates University, United Arab Emirates

Sally dhruva' Stephenson, Frosterburg State University, USA

Shaik. Feroz, Caledonian College of Engineering, Oman

Shiv Prasad, Maharshi Dayanand Saraswati University, India

Shujen Lee, Asia University, Taiwan

Shun-Hsing Chen, Oriental Institute of Technology, Taiwan

Soon Song, Wonkwang University, South Korea

Stacey Jocoy, Texas Tech University, USA

Sunil Kumar, Alliance University, India

T.S.Devaraja, University of Mysore, Hemagangothri Campus, India

Tan Khay Boon, SIM Global Education, Singapore

Theeraphab Phetmalaikul, Srinakharinwirot University, Thailand Vijayaletchumy Subramaniam, Universitas

Putra Malaysia, Malaysia Wang Yu-Shan, National Kaohsiung First University of Science and Technology,

Taiwan

Wei-Cheng Mau, Wichita State University, USA

Yong-Ho Kim, Pukyong National University, South Korea

Yong-Taek Rhim, Namseoul University, South Korea 
Approved at the meeting of the editorial board International Symposium on Education, Psychology and Social Sciences Proceedings ISEPSS; September, 28 2019: OEAPS Inc.\& COREF University of Tokyo; Chief Editor Jamie Halsall. Tokyo, Japan : OEAPS Inc., 2019. -110 P. ISBN:9781707482818

Number layout 04.11.2019

Signed in print 07.11.2019

Published on 11.11.2019

https://doi.org/10.6084/m9.figshare.10283471.v3

The paper used in this publication meets the requirements of ANSI/NISO Z39.48-1992 (Permanence of Paper) 



\section{Contents}

Андрей Петрович Мазуренко, Анжела Валерьевна Мещерякова

Реформирование государственной службы в постсоветской России: историко-правовой аспект

Оксана Васильевна Хрипункова

Проблема любви и пола в культурфилософских воззрениях

Д.С. Мережковского

Раиса Николаевна Афонина, Елена Алексеевна Лесных

$22-28$

К вопросу о соотношении понятий «педагогическая технология» и «технология обучения»

Раиса Николаевна Афонина

Особенности творческой деятельности студентов в условиях современного образовательного процесса

Atsushi Ishii

Experienced by ward nursery teachers Qualitative examination of moral problems

Elmira Tursinovna Akhmetova, Zhanna Borisovna Erzhanova

Self-work assignments as the most important form of teaching students

Elmira Tursinovna Akhmetova

The relevance of language learning in higher education institutions

Zarina Abdikamalkyzy Raiymkul

$60-65$

New techniques and methods in foreign language teaching

Algoere Turki Naif, Hasani Mohd Ali

66-95

Corporate governance developments in the saudi arabia and malaysia

N. Meyer, E. Keyser

96-109

Does having children really make a difference: the case of south african female entrepreneurs 



\section{Реформирование государственной службы

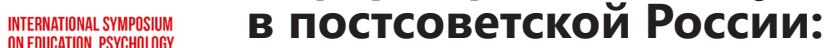 \\ AND SOCIAL SCIENCES \\ SEPTEMBER, 282019 историко-правовой аспект}

\section{Reform of public service in post-Soviet Russia: historical and legal aspect}

Мазуренко Андрей Петрович

доктор юридических наук, дочент,

Северо-Кавказский институт Российской академии народного хозяйства

и государственной службы при Президенте Российской Федерачии,

профессор кафедры правового обеспечения деятельности органов власти,

Россия, г. Пятигорск

decanpetrovich@mail.ru

Мещерякова Анжела Валерьевна

кандидат исторических наук, дочент,

Юридический факультет Северо-Кавказского федерального университета,

заведующий кафедрой теории и истории государства и права,

Россия, г. Пятигорск

ladyflam68@mail.ru

Mazurenko Andrey Petrovich

Doctor of Law, Associate Professor,

North Caucasian Institute of the Russian Academy of National Economy

and Public Administration under the President of the Russian Federation,

Professor, Department of Legal Support for the Activities of Authorities,

Russia, Pyatigorsk

Meshcheryakova Angela Valerievna

Candidate of Historical Sciences, Associate Professor,

Faculty of Law, North Caucasus Federal University,

Head of the Department of Theory and History of State and Law,

Russia, Pyatigorsk

Аннотация: рассматриваются особенности процесса реформирования государственной службы в Российской Федерации после развала СССР. Делаются авторские выводы о перспективах развития данного института в условиях современной России. Ключевые слова: государственная служба; реформирование; постсоветская Россия; правовое регулирование.

Abstract: The features of the process of reforming public service in the Russian Federation after the collapse of the USSR are considered. The author draws conclusions about the prospects for the development of this institution in modern Russia.

Keywords: public service; reform; post-Soviet Russia; legal regulation. 


\section{International Symposium on Education, Psychology and Social Sciences}

Как известно, развал СССР в декабре 1991 г., крушение административно-командной системы и всеобъемлющий кризис власти поставили страну перед необходимостью создания новой системы управления. Как отмечает В.Г. Игнатов, правовая основа российской государственности в конце 1991 - начале 1992 г. была довольно противоречивой. Она базировалась на законах, унаследованных от СССР, и законах РСФСР как составной части Союза. Такая противоречивость конституционной базы России была объективно обусловлена ее эволюционным переходом к новым принципам построения государства, общества и взаимоотношений между ними [2, с. 78].

Генезис российской государственности в постсоветский период - это непрерывный процесс совершенствования системы публичной власти на всех уровнях в целях обеспечения эффективного управления отраслями экономики и территориями страны. Вопрос укрепления российской государственности, совершенствования организации и повышения эффективности государственной службы стал о главу угла общественной жизни. А.В. Оболонский отмечает, что в этот период российская административная система стала работать хуже, ибо, сохранив почти все свои прежние недостатки, приобрела и новые. Наиболее очевидный из них - снижение уровня профессионализма вследствие того, что наиболее квалифицированные и способные аппаратчики покинули государственную службу, в основном переместившись в коммерческие структуры [4, с. 79]. Такое положение объективно требовало форми- рования новой правовой базы государственной службы.

В 1992-1993 гг. обострились противостояния между исполнительной властью и советами. 21 сентября 1993 г. Президент России Б.Н. Ельцин издал Указ № 1400 «О поэтапной конституционной реформе в России», которым было объявлено о роспуске Верховного Совета, Съезда народных депутатов РФ и проведении выборов в двухпалатное Федеральное Собрание. Выборы 12 декабря 1993 г. и принятие новой Конституции РФ заложили правовые основы новой российской государственности.

Официально начало реформированию государственной службы в новой России было положено принятием Положения о федеральной государственной службе, которое было утверждено Указом Президента РФ от 22 декабря 1993 г. № 2267 [5]. Через два года правовые основы государственной службы, конкретные принципы ее организации, правового положения (статуса) госслужащих, а также порядок поступления на государственную службу и ее прохождения установил Федеральный закон от 31 июля 1995 г. № 119-Ф3 «Об основах государственной службы Российской Федерации» (далее - Закон № 119-Ф3) [6]. Однако Закон не стал актом прямого действия, поскольку его реализация потребовала принятия множества подзаконных правовых актов. Наиболее значимым из них стал Указ Президента РФ от 6 сентября 1995 г. № 900 «О первоочередных мерах по улучшению работы с кадрами в системе государственной службы и реализации 


\section{International Symposium on Education, Psychology and Social Sciences}

Федерального закона «Об основах государственной службы Российской Федерации».

В период вступления в силу Закона «Об основах государственной службы Российской Федерации», летом 1995 г. были приняты 124 указа Президента Российской Федерации и 71 постановление Правительства Российской Федерации по различным вопросам государственной службы. Однако не были предприняты попытки подготовки и принятия предусмотренных федеральных законов. Субъекты Российской Федерации в вопросах государственной службы оказались впереди федерального центра. Наличие в субъектах Федерации собственного развитого законодательства отчетливо указывает на существовавший в тот момент правовой вакуум в урегулировании вопросов единой системы государственной службы Российской Федерации [1, с. 15]. В 1993-1998 годах законодательные акты по вопросам государственной службы были приняты более чем в 78 субъектах РФ.

К 2000 году в России было достигнуто укрепление вертикали власти и улучшение взаимодействия ее ветвей, стабилизировалась экономическая ситуация. Эти и иные позитивные факторы создали объективные предпосылки для совершенствования государственной службы. Необходимость ее реформирования объективно была обусловлена наличием ряда проблем в самой государственной службе [14, с. 206-208]. Цели и задачи оптимизации госслужбы были определены Концепцией реформи- рования системы государственной службы, утвержденной Президентом России 15 августа 2001 г. № Пр-1496.

Реформирование государственной службы в 2000-е гг. осуществлялось в увязке с общей стратегией совершенствования организации и повышения эффективности системы государственного управления. Указом Президента России от 12 августа 2002 г. № 885 были утверждены общие принципы служебного поведения государственных служащих [7], а Указом от 19 ноября 2002 г. № 1336 - Федеральная программа «Реформирование государственной службы Российской Федерации (20032005 годы)» [8]. В деле реализации задач по реформированию государственной службы Российской Федерации, определенных Концепцией и Программой, важным шагом стало принятие Федерального закона № 58-Ф3 (далее - Закон № 58-Ф3) «О системе государственной службы Российской Федерации» [9].

Формирование нового облика государственной службы России проходило в условиях проведения административной реформы, означавшей в узком смысле коренную перестройку государственного аппарата (гражданской службы). Указом Президента РФ от 9 марта 2004 г. № 314 «О системе и структуре федеральных органов исполнительной власти» [10] была определена новая их структура государственного управления. Дальнейшее развитие и активизация административной реформы в России были обеспечены путем разработки и реализации Концепции административной реформы в Российской Федерации, 


\section{International Symposium on Education, Psychology and Social Sciences}

одобренной распоряжением Правительства РФ от 25 октября 2005 г. № 1789-р [11].

Второй этап реформирования государственной службы в России в 2000-е гг. начался принятием Федерального закона от 27 июля 2004 г. № 79-Ф3 «О государственной гражданской службе Российской Федерации», который вступил в силу 1 февраля 2005 г. [12]. В.Д. Граждан отмечает, что в течение 2004-2006 гг. было принято 6олее 20 указов Президента РФ и множество постановлений Правительства РФ, в которых апробировались, нормативно оформлялись и совершенствовались механизмы функционирования государственной гражданской службы как вида государственной службы, стабилизировалась его структура, оптимизировался состав гражданских служащих [3, с. 28].

Вместе с тем критический анализ результатов проделанной в России с начала 2000-х работы по реформированию государственной службы показывает, что еще не достигнуто существенное повышение эффективности государственного управления, не до конца сформирована единая система государственной службы, не создана эффективная система управления государственной службой. Следовательно, проблема реформирования государственной службы в России по-прежнему актуальна, о чем свидетельствует продолжающееся совершенствование нормативной базы [1, с. 16].

\section{Список литературы}

1. Борисов Н.И. Государственная и муниципальная служба: учебное пособие. М.: КноРус, 2017. - 472 c.

2. Государственная служба: учебник / под ред. В.Г. Игнатова. - Ростов н/Д: МарТ, 2004. -942 c.

3. Граждан В.Д. Государственная гражданская служба: учебник. - М.: КноРус, 2007. - 497 c.

4. Оболонский А.В., Барабашев А.Г., Краснов М.А. Государственная служба: комплексный подход. - М.: Дело, 2009. $440 \mathrm{c}$.

5. Собрание актов Президента и Правительства РФ. - 1993. - № 52. - Ст. 5073.

6. С3 РФ. - 1995. - № 31. - СТ. 2990.

7. СЗ РФ. - 2002. - № 33. - Ст. 3196.

8. СЗ РФ. - 2002. - № 47. - СТ. 4664.

9. СЗ РФ. - 2003. - № 22. - СТ. 2063.

10. С3 РФ. - 2004. - № 11. - Ст. 945.

11. СЗ РФ. - 2005. - № 46. - СТ. 4720.

12. С3 РФ. - 2004. - № 31. - Ст. 3215.

13. Указ Президента РФ от 24.06.2019 г. № 288 «Об основных направлениях развития государственной гражданской службы Российской Федерации на 2019-2020 годы» // СПС КнсультантПлюс. URL: http://www.consultant.ru/ document/cons_doc_LAW_327379/ (дата обращения 27.09.2019).

14. Управление государственной гражданской службой Российской Федерации: монография / под общ. ред. А.И. Турчинова. - М.: Изд-во РАГС, 2009. - 242 c. 
International Symposium on Education, Psychology and Social Sciences

\section{The text of the article in English}

As you know, the collapse of the USSR in December 1991, the collapse of the administrative-command system and a comprehensive crisis of power put the country before the need to create a new management system. As noted by V.G. Ignatov, the legal basis of Russian statehood in late 1991 - early 1992 was rather controversial. It was based on laws inherited from the USSR and the laws of the RSFSR as an integral part of the Union. Such inconsistency of the constitutional base of Russia was objectively due to its evolutionary transition to new principles of building a state, society and the relationship between them [2, p. 78].

The genesis of Russian statehood in the post-Soviet period is a continuous process of improving the system of public authority at all levels in order to ensure effective management of economic sectors and territories of the country. The issue of strengthening Russian statehood, improving the organization and improving the efficiency of public service has become a cornerstone of public life. A.V. Obolonsky notes that during this period the Russian administrative system began to work worse, for, having retained almost all of its previous shortcomings, it acquired new ones. The most obvious of them is a decrease in the level of professionalism due to the fact that the most qualified and capable apparatchiks left the civil service, mainly moving to commercial structures [4, p. 79]. This situation objectively required the formation of a new legal framework for public service.
In 1992-1993 Confrontation between the executive branch and the soviets intensified. September 21, 1993. President of Russia B.N. Yeltsin issued Decree No. 1400 "On Phased Constitutional Reform in Russia," which announced the dissolution of the Supreme Council, the Congress of People's Deputies of the Russian Federation, and the holding of elections to the bicameral Federal Assembly. The elections of December 12, 1993 and the adoption of the new Constitution of the Russian Federation laid the legal foundations of the new Russian statehood.

Officially, the reform of public service in new Russia began with the adoption of the Regulation on the Federal Public Service, which was approved by Decree of the President of the Russian Federation of December 22, 1993 No. 2267 [5]. Two years later, the legal foundations of the civil service, the specific principles of its organization, the legal status (status) of civil servants, as well as the procedure for entering and serving the civil service, were established by Federal Law No. 119-FZ of July 31, 1995 "On the Basics of the Civil Service of the Russian Federation «(Hereinafter - the Law No. 119-Ф3) [6]. However, the Law did not become an act of direct action, since its implementation required the adoption of many by-laws. The most significant of these was Presidential Decree No. 900 of September 6, 1995, "On Priority Measures to Improve Work with Personnel in the Civil Service System and Implementation of the Federal Law" On the Fundamentals of the Civil Service of the Russian Federation ". 


\section{International Symposium on Education, Psychology and Social Sciences}

During the entry into force of the Law "On the Fundamentals of the Civil Service of the Russian Federation", in the summer of 1995124 decrees of the President of the Russian Federation and 71 resolutions of the Government of the Russian Federation on various issues of public service were adopted. However, no attempts were made to prepare and adopt the envisaged federal laws. The subjects of the Russian Federation in matters of public service were ahead of the federal center. The presence in the constituent entities of the Federation of their own developed legislation clearly indicates the legal vacuum that existed at that time in resolving issues of a unified civil service system of the Russian Federation [1, p. fifteen]. In 1993-1998, legislative acts on public service issues were adopted in more than 78 constituent entities of the Russian Federation.

By 2000, in Russia, the vertical of power was strengthened and the interaction of its branches improved, and the economic situation stabilized. These and other positive factors created objective prerequisites for improving public service. The need for its reform was objectively determined by the presence of a number of problems in the public service itself [14, p. 206-208]. The goals and objectives of optimizing the civil service were determined by the Concept of reforming the civil service system, approved by the President of Russia on August 15, 2001 No. Pr-1496.

Civil Service Reform in the 2000s carried out in conjunction with the overall strategy of improving the organization and improving the effectiveness of the public administration system. By the Decree of the President of Russia dated August 12, 2002 No. 885, the general principles of the official conduct of public servants were approved [7], and by Decree of November 19, 2002 No. 1336 the Federal Program "Reform of the Civil Service of the Russian Federation (2003-2005)" [ 8]. In the implementation of the tasks of reforming the public service of the Russian Federation, defined by the Concept and Program, an important step was the adoption of Federal Law No. 58- Ф3 (hereinafter - Law No. 58-Ф3) "On the Civil Service System of the Russian Federation" [9].

The formation of a new image of the public service of Russia took place in the context of an administrative reform, which in the narrow sense meant a radical restructuring of the state apparatus (civil service). By the Decree of the President of the Russian Federation of March 9, 2004 No. 314 "On the System and Structure of the Federal Executive Bodies" [10], their new government structure was determined. Further development and intensification of administrative reform in Russia was ensured through the development and implementation of the Concept of administrative reform in the Russian Federation, approved by Decree of the Government of the Russian Federation of October 25, 2005 No. 1789-p [11].

The second stage of public service reform in Russia in the 2000s. It began with the adoption of the Federal Law of July 27, 2004 No. $79-F Z$ "On the State Civil Service of the Russian Federation", which entered into force on February 1, 2005 [12]. V.D. Citizens notes 
International Symposium on Education, Psychology and Social Sciences

that during 2004-2006. more than 20 decrees of the President of the Russian Federation and many resolutions of the Government of the Russian Federation were adopted, in which the mechanisms of functioning of the state civil service as a type of public service were tested, normally formalized and improved, its structure was stabilized, and the composition of civil servants was optimized [3, p. 28].

At the same time, a critical analysis of the results of public service reform work carried out in Russia since the early 2000s shows that a significant increase in the effectiveness of public administration has not yet been achieved, a unified civil service system has not been fully formed, and an effective public service management system has not been created. Consequently, the problem of reforming the civil service in Russia is still relevant, as evidenced by the ongoing improvement of the regulatory framework [ 1 , p. 16]. 


\title{
Проблема любви и пола в культурфилософских

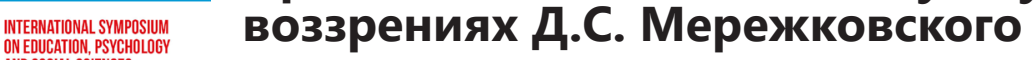 AND SOCIAL SCIENCES \\ SEPTEMBER, 282019 TOKYO - JAPAN \\ The problem of love and gender in the cultural and philosophical views of D.S. Merezhkovsky
}

\section{Хрипункова Оксана Васильевна}

Старший преподаватель

Санкт-Петербургский государственный экономический университет,

Россия, Санкт-Петербург

khripunkova.oxana@yandex.ru

\section{Khripunkova Oksana Vasilyevna}

Senior lecturer

Saint-Petersburg State University of Economics,

Russia, Saint Petersburg

\section{Аннотация: В статье рассматривается проблема любви и пола в творчестве Д.С. Мережковского. Обосновывается идея о том, что данная проблема в творчестве писателя и мыслителя представлена в контексте его представлений о преображенном поле. Анализируется реализация данной темы в философско-публицистических произведениях Д.С. Мережковского.}

Ключевые слова: любовь; пол; философия любви; Серебряный век; андрогин.

\begin{abstract}
The author of the report considers the the problem of love and gender in the works of D.S. Merezhkovsky. The author substantiates the idea that this problem in the works of the writer and philosopher is connected with his idea of the transfigured gender. The report analyzes the implementation of this problem in the philosophical works of D.S. Merezhkovsky.
\end{abstract}

Keywords: love; gender; philosophy of love; Silver age; androgynous. 


\section{International Symposium on Education, Psychology and Social Sciences}

На рубеже XIX-XX веков русская культура переживала достаточно серьезную переоценку ценностей и традиций. Вследствие этого появилась необходимость интерпретировать те идеи, которыми пользовались ранее и трансформировать прежние ценности. Именно в этот период и назревала особенная культурно-философская модель, которая, по мнению Хорунжия, выражала бы сущность нового этапа культуры. $[7$, c. 53].

В конце XIX века одним из главных предметов осмысления стала проблема любви и пола - именно с нею мыслители того времени напрямую связывали постижение личности человека. Своеобразие подхода именно русской интеллигенции к данной проблеме заключалась в широком ее понимании и синкретизме, так как на рубеже XIX-XX веков философия любви стала «и этикой, и эстетикой, и психологией, и постижением божественного» $[6$, с. 7$]$.

Исследуя природу таких понятий, как «любовь» и «пол», отечественные мыслители приходили к идее о космизации отношений между полами. Любовь понимается ими как попытка распознать божественное начало в любимом человеке. Вследствие такого обожествления отношений между мужчиной женщиной в русской культурфилософии появляется понятие «обожения» пола. В понимании философов Серебряного века «обожением» было стремление придать духовность телу и телесность духу.

По словам исследователя М.В. Чистовой, «пол, осмысляемый в религиозно-мисти- ческом аспекте, вводится в пространство божественной ипостасности, прообразы которой преображают привычные интимные отношения полов возможностью возвращения к догреховной целостности, и в пространство любви, понимаемой в качестве особого феномена бытия, позволяющего преодолевать половую разделенность» $[8$, с. $7-8]$.

Особенную актуальность в этом контексте приобретает творчество Д.С. Мережковского, являющегося знаковой фигурой русского Ренессанса. Любовь занимает наивысшую ступень в иерархии общечеловеческих и культурных ценностей в культурфилософском наследии мыслителя. Рассматривая любовь как источник ценностей, Д.С. Мережковский считает её высшей добродетелью на земле. Мыслитель уверен, что именно любовь освобождает личность от эгоизма и эгоцентризма и предоставляет человеку возможность осознать собственную ценность, ведь она помогает одному человеку увидеть в другом то единственное и неповторимое, что делает человека личностью.

Наиболее понятной и доступной человеку формой любви, известной практически каждому, является, по мнению Д.С. Мережковского, любовь между полами - земная, «брачная» любовь мужчины и женщины, которую хоть раз ощутил каждый человек. Опыт брачной любви - земного эроса, отмечает Д.С. Мережковский, знаком всем. И то, что страшит и пугает в любви небесной - «агапе» по Евангелию - в эросе выглядит просто, легко и радостно, ибо влюбленные 


\section{International Symposium on Education, Psychology and Social Sciences}

делятся друг с другом последним, что у них есть. По мнению мыслителя, именно в этом естественном для любого человека бесхитростном чувстве каждый может понять и ощутить, что значит любить: «Только здесь, в эросе, сказал впервые человек человеку: "Люблю", назвал любовь по имени» [4].

Мережковский был уверен в том, что телесное воплощение личности играет весьма важную роль как в мирской, так и в духовной жизни человека. Отрицать его ни в коем случае нельзя, так как Христос, согласно Библии, воскрес не духовно, а телесно. Мыслитель утверждал, что «Христос освящает плоть, <...> аскетизм Христа есть преображение пола, а не его отрицание» [3, с. 403.] и что «будущность пола - в стремлении к новой христианской влюбленности» [3, с. 403.]. В ней для автора заключалась идея преображения личности человека в целом, а не только его полового аспекта.

Смертность человека Мережковский также связывает с проблемой пола, а именно - с потерей человеком своей былой андрогинной целостности. Смерть, по его мнению, являлась печальным последствием разделения некогда целостной личности на два разных пола. В результате такого разделения в человеке, согласно Мережковскому, появилась некая брешь, через которую и проникает смерть: «Пол является половиной личности - независимо от того мужской или женской. Именно половое расщепление является корнем и основной проблемой смерти, именно оно приводит к распаду личности». [5, с. 311-312].
По мнению автора, половая любовь является первым шагом к тому, чтобы мужчина и женщина воссоздали утраченное некогда единство. Мужское начало стремится к женскому, женское - к мужскому, что является извечным бессознательным желанием каждого человека однажды воссоединиться в целостном бессмертном существе - андрогине. Древний миф об андрогинах в концепции Мережковского преобразовался в принцип, согласно которому и происходит восстановление целостной личности.

Само по себе притяжение двух полов мыслитель объяснял как стремление каждого человека найти утерянную целостность и обрести божественное бессмертие. Он писал, что половая любовь двух людей это путь к воскресению, который не имеет конца. Стремление двух половин друг к другу, как правило, тщетно и они то соединяются, то распадаются вновь. Воскреснуть же люди не могут, они только рождаются и умирают. [5, с. 312].

Андрогин, по мнению Мережковского это такой же символ, который содержит в себе тайное знание о том, как взаимодействуют между собой космические начала, которые то отталкиваются, то переживают притяжение. Именно этот символ дает возможность понять метафизическое родство двух душ, которые пытаются восстановить единство, утерянное ранее. Философема андрогина содержит в себе также идею мистического брака, а также смысла духовной эволюции человека и вселенской соборности [1, с. 22]. 


\section{International Symposium on Education, Psychology and Social Sciences}

Таким образом, любовь между мужчиной и женщиной в культурфилософских воззрениях Д.С. Мережковского превращается в идею обретения человеком целостности как гармонии двух начал. Однако, по мнению мыслителя, такой идеал не может быть осуществлен на данный момент, потому что развитие человечества еще не достигло такого уровня. Однако эта целостность, согласно утверждению Мережковского, будет полностью реализована в Царстве Третьего Завета, которое станет новой ступенью эволюции человека. По мнению мыслителя, изменения, которые произойдут с человеческим сознанием и телом, дадут человечеству возможность полностью физически преодолеть смерть. Мережковский уверен, что смерть будет побеждена, а воскрешение будет означать восстановление целостной личности. Именно такая целостная личность, которая полностью закрыта, получит возможность защититься от смерти, будет недоступна для нее, как полностью замкнутый шар: «Целая, исцеленная личность для смерти закрыта, замкнута, как совершенный круг или шар - ... «двуполый шар» Андрогина» [5, c. 312].

\section{Список литературы}

1. Королькова Е.А. Метафизика любви в творчестве Д. Мережковского и 3. Гиппиус: текст лекции. СПб.: ГУАП., 2006. 31c.

2. Лосский Н.О. История русской философии. М.: Академический проект, 2007. 551 c.

3. Мережковский Д.С. Новый Вавилон // Розанов B.B.: Pro et contra. Антология: в
2 Кн. СПб.: РХГИ, 1995. Кн. 2. 510 с.

4. Мережковский Д.С. Тайна Запада: Атлантида-Европа. - [Электронный pecyp]. - URL: https://www.litmir.me/ $\mathrm{br} / ? \mathrm{~b}=102539 \& \mathrm{p}=46$ (дата обращения: 20.10.2019).

5. Мережковский Д.С. Тайна Трёх. Египет-Вавилон. М.: ЭКСМО, 2005. 557 с.

6. Русский Эрос, или Философия любви в России / Сост. и авт. вступ. ст. В.П. Шестаков; коммент. А.Н. Богословского. М.: Прогресс, 1991. 448 с.

7. Хорунжий С.С. Трансформация славянофильской идеи в XX в. // Вопросы философии. 1994. №11. С. 54-59.

8. Чистова М.В. Концепт Андрогина в жизнетворчестве 3.Н. Гиппиус: автореф. на соиск. ученой степ. канд. культ.: 24.00.01 - теория и история культуры Кострома, 2004, 23 c.

\section{The text of the article in English}

At the turn of the nineteenth and twentieth centuries, Russian culture experienced a rather serious reappraisal of values and traditions. As a result, it became necessary to interpret the ideas that were used earlier and to transform the old values. It was during this period that a special cultural-philosophical model was brewing, which, according to Khorunzhiy, would express the essence of a new stage of culture. [7, p. 53].

At the end of the 19th century, one of the main subjects of comprehension was the problem of love and sex - it was with her that the thinkers of that time directly linked comprehension of a person's personality. The 


\section{International Symposium on Education, Psychology and Social Sciences}

peculiarity of the approach of the Russian intelligentsia to this problem consisted of its broad understanding and syncretism, since at the turn of the 19th-20th centuries the philosophy of love became "ethics, aesthetics, psychology, and comprehension of the divine" $[6$, p. 7].

Exploring the nature of such concepts as "love" and "gender", domestic thinkers came up with the idea of cosmizing relations between the sexes. Love is understood by them as an attempt to recognize the divine principle in a loved one. Due to this deification of relations between a man and a woman, the concept of "deification" of gender appears in Russian cultural philosophy. In the understanding of the philosophers of the Silver Age, "deification" was the desire to give spirituality to the body and physicality to the spirit.

According to the researcher M.V. Pure, "sex, interpreted in a religious-mystical aspect, is introduced into the space of divine hypostasis, the prototypes of which transform the familiar intimate relationships of the sexes with the possibility of a return to pre-sinful integrity, and into the space of love, understood as a special phenomenon of being that allows us to overcome sexual separation" [8, from. 7-8].

Of particular relevance in this context is the work of D.S. Merezhkovsky, who is an iconic figure of the Russian Renaissance. Love takes the highest step in the hierarchy of universal and cultural values in the philosophical heritage of the thinker. Considering love as a source of values, D.S. Merezhkovsky considers her the highest virtue on earth. The thinker is sure that it is love that frees a person from selfishness and self-centeredness and provides a person with the opportunity to realize their own value, because it helps one person to see in the other the one and only that makes a person a person.

According to D.S., the most understandable and accessible to man form of love, known to almost everyone, is Merezhkovsky, the love between the sexes - earthly, «marriage» love of a man and a woman, which at least once every person felt. The experience of marriage love - earthly eros, notes D.S. Merezhkovsky, familiar to everyone. And what scares and scares in heavenly love - "agape" according to the Gospel - in Eros looks simple, easy and joyful, for lovers share with each other the last that they have. According to the thinker, it is in this unsophisticated feeling that is natural for any person that everyone can understand and feel what it means to love: "Only here, in eros, did a person first say to a person:" I love, "called love by name" [4].

Merezhkovsky was convinced that the bodily embodiment of personality plays a very important role in both worldly and spiritual life. In no case can it be denied, because Christ, according to the Bible, did not rise spiritually, but bodily. The Thinker claimed that «Christ sanctifies the flesh, <...> Christ's asceticism is the transformation of sex, not his denial $[3$, p. 403.] and that «thefuture of sex is in the pursuit of a new Christian love» $[3$, p. 403.]. It was for the author the idea of transforming the personality of a person as a whole, and not just his sexual aspect. 


\section{International Symposium on Education, Psychology and Social Sciences}

Merezhkovsky also associates human mortality with the problem of gender, namely, with the loss by a person of his former androgynous integrity. Death, in his opinion, was a sad consequence of the division of the once holistic personality into two different sexes. According to Merezhkovsky, as a result of such a separation, a certain gap appeared through which death penetrates: "Sex is half the personality - regardless of whether it's male or female. It is sexual splitting that is the root and main problem of death, it is precisely this that leads to the decay of the individual. " [5, p. 311-312].

According to the author, sexual love is the first step to ensure that the man and woman recreate the once lost unity. The masculine principle aspires to the feminine, the feminine to the masculine, which is the eternal unconscious desire of each person to reunite once in an integral immortal being - androgyne. The ancient myth of the androgyne in the concept of Merezhkovsky was transformed into the principle according to which the restoration of a holistic personality takes place.

The thinker himself explained the attraction of two sexes as the desire of each person to find lost integrity and gain divine immortality. He wrote that the sexual love of two people is a path to resurrection that has no end. The desire of the two halves to each other, as a rule, is in vain and they are either connected or disintegrated again. People cannot resurrect, they are only born and die. [5, p. 312].
Androgin, according to Merezhkovsky, is the same symbol that contains a secret knowledge about how cosmic principles interact, which either repulse or survive attraction. It is this symbol that makes it possible to understand the metaphysical kinship of two souls who are trying to restore the unity that was previously lost. The androgyne philosophy also contains the idea of a mystical marriage, as well as the meaning of the spiritual evolution of man and universal collegiality [1, p. 22].

Thus, the love between a man and a woman in the cultural philosophical views of D.S. Merezhkovsky turns into the idea of gaining human integrity as a harmony of two principles. However, according to the thinker, such an ideal cannot be realized at the moment, because the development of mankind has not yet reached such a level. However, this integrity, according to Merezhkovsky, will be fully realized in the Kingdom of the Third Testament, which will become a new stage in the evolution of man. According to the thinker, the changes that will occur with the human mind and body will give humanity the ability to completely physically overcome death. Merezhkovsky is sure that death will be defeated, and the resurrection will mean the restoration of a holistic personality. It is such a holistic person who is completely closed, who will be able to defend himself against death, will not be available to her, like a completely closed ball: "A whole, healed person for death is closed, closed like a perfect circle or ball -... Androgin's" bisexual ball "[ 5, p. 312]. 


\title{
К вопросу о соотношении понятий «педагогическая \\ INTERNATIONAL SYMPOSIUM ON EDUCATION, PSYCHOLOG технология» и «технология обучения»
}

SEPTEMBER, 282019

\section{To the question of the relationship of the concepts of «pedagogical technology» and «teaching technology»}

\section{Афонина Раиса Николаевна}

дочент

Алтайский государственный педагогический университет

Россия, г.Барнаул

ARN1960@yandex.ru

\section{Лесных Елена Алексеевна}

дочент

Алтайский государственный аграрный университет

Россия, г.Барнаул

lesnyh74@mail.ru

\author{
Afonina Raisa Nikolaevna \\ assistant professor \\ Altai State Pedagogical University \\ Russia, Barnaul \\ Lesnykh Elena Alekseevna \\ assistant professor \\ Altai State Agrarian University \\ Russia, Barnaul
}

Аннотация: Статья посвящена рассмотрению сущности понятий «технология», «педагогическая технология» и «технология обучения». Анализируются ведущие подходы к пониманию термина «педагогическая технология» и устанавливается иерархическая соподчиненность рассматриваемых понятий.

Ключевые слова: педагогическая технология, технология обучения, теория обучения, методика обучения.

Summary: The article is devoted to consideration of the essence of the concepts of «technology», «pedagogical technology» and «learning technology». The leading approaches to understanding the term «pedagogical technology» are analyzed and a hierarchical subordination of the concepts under consideration is established.

Key words: pedagogical technology, teaching technology, learning theory, teaching methods. 


\section{International Symposium on Education, Psychology and Social Sciences}

Общее толкование понятия «технология» - techne - искусство, мастерство и logos - наука, учение приводит к дословному пониманию технологии как науки о мастерстве. Рассматривая значения термина «технология» в историческом аспекте следует отметить, что термин «технология» в науку впервые ввел математик Г. Лейбниц (1647-1716). В философском словаре дается следующее определение понятия «технология»: «технология - это набор и последовательность операций, выполненных с помощью данной техники в каждом данном определенном производственном процессе»[9]. Данное определение имеет достаточно общий характер. Таким образом, технология с точки зрения философии рассматривается как наука о средствах достижения цели, об опыте и навыках; о процессе преобразования любой деятельности; о процессах социального потребления. Термин «технология» применяется обычно в производственной сфере. Технологические процессы, в отличие от стихийных процессов, представляют собой, структурно-системные процессы целесообразно организованной упорядоченной деятельности [5].

Долгое время считалось, что термин «технология» применительно к педагогике не может использоваться, так как в процессе обучения и воспитания участвуют живые люди, которые не поддаются «стандартизации». Вместе с тем, история педагогики имеет убедительные доказательства того, что педагогическая деятельность начала технологизироваться задолго до того, как большинство педагогов, ученых и практи- ков осознали объективность протекающих процессов. Подтверждением этому является классно-урочная система Я.А. Коменского, наглядное обучение Песталоцци.

Впервые термин «технология обучения» появился в США и трактовался как способ оптимального построения и реализации учебного процбесса с учетом целей обучения. В работе Дж. Бруннера [2] технология обучения определяется как своеобразный инструмент дидактической работы, как область знания, связанная с определением системы предписаний, обеспечивающих оптимизацию процесса обучения.

Сегодня существует множество точек зрения на понимание и употребление термина «педагогическая технология». Анализируя термин «технология обучения» Н.Ф. Талызина[8], определяет в качестве главного характеризующего признака практическую направленность. Педагогическая технология, как пишет А.З. Рахимов «это совокупность знаний о способах и средствах организации учебной деятельности, ведущих к качественным изменениям в личности обучаемых и достижению заданных результатов» [6]. Структурируя понятие «технология обучения», М.В. Кларин [4] выделяет в нем такие компоненты как: постановка целей обучения; ориентация обучения (его ход и последовательность) на учебные цели и результаты обучения; промежуточный контроль и коррекцию знаний, направленную на реализацию целей обучения, заключительную оценку результатов обучения. 


\section{International Symposium on Education, Psychology and Social Sciences}

Современные педагогические технологии, как подчеркивается В.П. Беспалько [1], являются средством развития классической дидактики. Это развитие выражено в следующих принципах: структурной и содержательной целостности технологии, ее диагностической направленности и интенсивности всех процессов.

Г.К. Селевко[7] выделяет основные методологические требования к педагогической технологии:

- концептуальность - наличие определенной научной концепции, включающей философское, психологическое, дидактическое и социально-педагогическое обоснование достижения образовательных целей;

- системность - обладание всеми свойствами системы: логикой процесса, взаимосвязью всех его частей, эмерджментными свойствами;

- управляемость - возможность диагностического целеполагания, планирования, проектирования результата обучения, поэтапной диагностики;

- эффективность - достижение оптимальных результатов при оптимальных затратах при гарантии определенных стандартов обучения;

- воспроизводимость - возможность применения (повторения, воспроизведения) педагогической технологии в других образовательных учреждениях, другими субъектами.

Анализируя работы отечественных и зарубежных авторов, М.А. Чошанов [10] выделяет, в частности, и такие признаки педагогической технологии как диагностическое целеобразование, результативность, эКОномичность и корректируемость. Диагностическое целеобразование и результативность предполагают гарантированное достижение целей и эффективность процесса обучения. Экономичность обеспечивает резерв времени, оптимизацию труда преподавателя и достижение запланированных результатов в сжатые промежутки времени. Корректируемость как возможность оперативной обратной связи, последовательно ориентированной на четко определенные цели.

В качестве основных компонентов образовательной технологии В.В. Гузеев [3] выделят следующие:

- некоторое диагностичное и операциональное представление планируемых результатов обучения;

- средства диагностики текущего состояния и прогнозирования тенденций ближайшего развития обучаемых;

- набор моделей обучения; критерии выбора или построения оптимальной модели обучения для данных конкретных условий.

Содержательное обобщение существующих определений понятия «педагогическая технология» представлено в работе Г.К. Селевко [7], где автор выделяет три аспекта этого понятия. Научный аспект: педагогическая технология - часть педагогической науки, изучающая и разрабатывающая цели, содержание и методы обучения и проектирующая педагогические процессы. Процессуально-описательный аспект: 


\section{International Symposium on Education, Psychology and Social Sciences}

как алгоритм процесса, совокупность целей, содержания, методов и средств достижения планируемых результатов обучения. Процессуально-действенный аспект: осуществление технологического процесса, функционирование всех личностных, инструментальных и методологических педагогических средств. Таким образом, К.Г. Селевко утверждает, что педагогическая технология функционирует и в качестве науки, исследующей более рациональные пути обучения, и в качестве системы способов, принципов, регулятивов, применяемых в обучении и в качестве реального процесса обучения.

Данное понимание технологии позволяет автору выделить три уровня ее существования: общепедагогический; частнометодический; локальный. Общепедагогическая технология характеризует целостный образовательный процесс в данном регионе, учебном заведении на определенной ступени обучения. Частнопредметная технология употребляется в значении «частная методика», либо как совокупность методов и средств для реализации определенного содержания обучения и воспитания в рамках одного предмета. Локальная технология представляет собой технологию отдельных частей учебно-воспитательного процесса, решение частных дидактических и воспитательных задач (технология отдельных видов деятельности, воспитание отдельных качеств личности, технология формирования новых знаний, повторения, контроля знаний, умений и навыков и т.д.). Неоднозначность определения понятий «педагогическая технология», «технология обучения», «теория обучения», «методика обучения» в научно-методической литературе приводит к тому, что многие авторы зачастую отождествляют эти понятия. Понятие «педагогическая технология» является более широким по отношению к понятию «технология обучения» и включает, в отличие от последней, еще и науку, исследующую наиболее рациональные пути обучения. Различие между теорий обучения и технологией обучения заключается в том, что теория обучения описывает идеальный процесс обучения, а технология обучения реализует идеальный процесс обучения в данных условиях.

\section{Список литературы}

1. Беспалько, В.П. Педагогика и прогрессивные технологии обучения / В.П. Беспалько. - М.: Институт профтехобразования МО РФ, 1995. - 336 с.

2. Брунер, Дж. Процесс обучения / Дж. Брунер. - М.: АПН РСФСР, 1962. - 84 с.

3. Гузеев, В.В. Планирование результатов образования и образовательная технология /В.В. Гузеев. - М.: Народное образование, 2000. - 240 с.

4. Кларин, М.В. Педагогическая технология в учебном процессе: анализ зарубежного опыта / М.В. Кларин. /- М.: Знание, 1989. - 77 с.

5. Колин, К. Будущее науки: методология познания и образовательные технологии / К. Колин // Вестник высшей школы. - 2000 . - №11. - С.38 - 46.

6. Рахимов, А.3. Психодидактика / А.3. Рахимов. - Уфа:Творчество, 1996.- 208 с. 


\section{International Symposium on Education, Psychology and Social Sciences}

7. Селевко, Г.К. Энциклопедия образовательных технологий /Г.К. Селевко. - М.: НИИ школьных технологий, 2006. - 816 C.

8. Талызина, Н.Ф. Формирование познавательной деятельности учащихся/ Н.Ф. Талызина.- М.: МГУ, 1969. -131 с.

9. Философский энциклопедический словарь/ Под ред. Л.Ф. Ильичева. - М: Советская энциклопедия, 1983. - 839 с.

10. Чошанов, М.А. Гибкая технология проблемно-модульного обучения / М.А. Чошанов. - М.: Народное образование, 1996. -160 c.

\section{The text of the article in English}

The general interpretation of the concept of "technology" - techne - art, craftsmanship and logos - science, teaching leads to a literal understanding of technology as a science of mastery. Considering the meaning of the term "technology" in historical aspect, it should be noted that the term "technology" was first introduced into science by the mathematician G. Leibniz (1647-1716). The philosophical dictionary gives the following definition of the concept of "technology": "technology is a set and sequence of operations performed using this technique in each given specific production process" [9]. This definition is quite general. Thus, technology from the point of view of philosophy is considered as a science about the means of achieving the goal, about experience and skills; about the process of transforming any activity; about the processes of social consumption. The term «technology» is usually used in the manufacturing sector. Technological processes, in contrast to spontaneous processes, are structural and system processes of a reasonably organized orderly activity [5].

For a long time it was believed that the term "technology" as applied to pedagogy cannot be used, since living people who cannot be "standardized" participate in the process of training and education. At the same time, the history of pedagogy has convincing evidence that pedagogical activity began to be technologically advanced long before most educators, scientists and practitioners realized the objectivity of the ongoing processes. Confirmation of this is the classroom system of Y.A. Comenius, visual training Pestalozzi.

For the first time, the term «learning technology» appeared in the United States and was interpreted as a way to optimally build and implement the educational process, taking into account the goals of training. In the work of J. Brunner [2], learning technology is defined as a kind of didactic work tool, as a field of knowledge associated with the definition of a system of prescriptions that optimize the learning process.

Today, there are many points of view on the understanding and use of the term "pedagogical technology". Analyzing the term «learning technology» N.F. Talyzina [8], defines a practical orientation as the main characterizing feature. Pedagogical technology, as A.Z. writes. Rakhimov "this is a body of knowledge about the ways and means of organizing educational activities leading to qualitative changes in the personality of students and the achievement of desired results" [6]. Structuring the concept 


\section{International Symposium on Education, Psychology and Social Sciences}

of «learning technology», M.V. Clarin [4] identifies such components in it as: setting learning goals; orientation of training (its course and sequence) towards educational goals and learning outcomes; intermediate control and correction of knowledge aimed at realizing learning objectives, final assessment of learning outcomes.

Modern pedagogical technologies, as emphasized by V.P. Bespalko [1], are a means of developing classical didactics. This development is expressed in the following principles: structural and substantial integrity of the technology, its diagnostic orientation and intensity of all processes.

G.K. Selevko [7] identifies the main methodological requirements for pedagogical technology:

- conceptuality - the presence of a specific scientific concept, including the philosophical, psychological, didactic and socio-pedagogical justification for achieving educational goals;

- systematicity - possession of all the properties of the system: the logic of the process, the interconnection of all its parts, emergent properties;

- controllability - the possibility of diagnostic goal-setting, planning, designing the result of training, phased diagnosis;

- efficiency - achieving optimal results at optimal costs while guaranteeing certain training standards;

- reproducibility - the possibility of applying (repeating, reproducing) pedagogical technology in other educational institutions, by other entities.
Analyzing the work of domestic and foreign authors, MA Choshanov [10] identifies, in particular, such features of pedagogical technology as diagnostic target formation, effectiveness, profitability, and correctability. Diagnostic targeting and performance require guaranteed achievement of goals and the effectiveness of the learning process. Profitability provides a reserve of time, optimization of the teacher's work and achievement of the planned results at short intervals. Adjustability as an opportunity for operational feedback, consistently focused on clearly defined goals.

As the main components of educational technology V.V. Guzeev [3] will distinguish the following:

- some diagnostic and operational presentation of the planned learning outcomes;

- diagnostic tools for the current state and forecasting trends of the nearest development of students;

- a set of learning models; selection criteria or constructing the optimal learning model for these specific conditions .

A meaningful generalization of existing definitions of the concept of "pedagogical technology" is presented in the work of G.K. Selevko [7], where the author identifies three aspects of this concept. Scientific aspect: pedagogical technology is a part of pedagogical science that studies and develops goals, content and teaching methods and designs pedagogical processes. The procedural and descriptive aspect: as a 


\section{International Symposium on Education, Psychology and Social Sciences}

process algorithm, a set of goals, content, methods and means of achieving the planned learning outcomes. The procedurally effective aspect: the implementation of the technological process, the functioning of all personal, instrumental and methodological pedagogical tools. Thus, K.G. Selevko argues that pedagogical technology functions both as a science that explores more rational ways of learning, and as a system of methods, principles, and regulations used in teaching and as a real learning process.

This understanding of technology allows the author to distinguish three levels of its existence: general pedagogical; private methodical; local. General pedagogical technology characterizes a holistic educational process in a given region, educational institution at a certain level of training. Private subject technology is used in the meaning of "private methodology", or as a combination of methods and means for implementing a certain content of training and education in the same subject. Local technology is the technology of individual parts of the educational process, the solution of private didactic and educational tasks (technology of certain types of activities, the education of individual personality qualities, the technology of the formation of new knowledge, repetition, control of knowledge, skills, etc.).

The ambiguity in the definition of the concepts of "pedagogical technology", "teaching technology", "teaching theory", "teaching methods" in the scientific and methodological literature leads to the fact that many authors often identify these concepts. The concept of "pedagogical technology" is broader in relation to the concept of "learning technology" and includes, in contrast to the latter, also science that explores the most rational ways of learning. The difference between learning theories and learning technology is that learning theory describes an ideal learning process, and learning technology implements an ideal learning process under given conditions. 


\title{
Особенности творческой деятельности студентов в

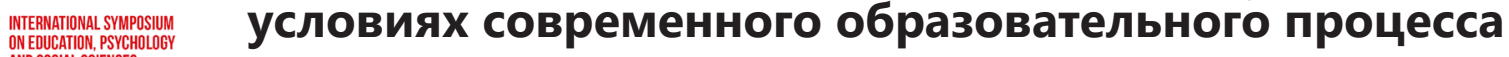 AND SOCIALS SCIENCES \\ SEPTEMBER, 282019 of the modern educational process
}

\section{Афонина Раиса Николаевна \\ дочент \\ Алтайский государственный педагогический университет \\ Россия, 2.Барнаул \\ ARN1960@yandex.ru}

\author{
Afonina Raisa Nikolaevna \\ assistant professor \\ Altai State Pedagogical University \\ Russia, Barnaul
}

\begin{abstract}
Аннотация: В статье рассматриваются особенности организации творческой деятельности студентов в образовательном процессе вуза. Существенными признаками творческой деятельности студентов выступают сознательное целеполагание, новизна, оригинальность, комбинирование, неограниченность в деятельности извне заданными рамками. Заинтересованность, самостоятельность, сознательность и активность студентов в творческой деятельности определяются характером организованности деятельности, формами и методами контроля результатов и отношений к ним.
\end{abstract}

Ключевые слова: учебная деятельность, творческая деятельность, образовательный процесс.

Abstract: The article discusses the features of the organization of creative activities of students in the educational process of the university. The essential signs of students' creative activity are conscious goal-setting, novelty, originality, combination, unlimitedness of activity from the outside by the given framework. The interest, independence, consciousness and activity of students in creative activity is determined by the nature of the organization of activity, forms and methods of monitoring the results and attitudes towards them.

Keywords: educational activity, creative activity, educational process. 


\section{International Symposium on Education, Psychology and Social Sciences}

Творческая деятельность рассматривается нами в первую очередь как один из видов учебно-познавательной деятельности, направленный на развитие противоречия в ходе решение творческой задачи, для которой необходимы объективные и субъективные условия, а результат обладает новизной, оригинальностью, личной и социальной значимостью.

Специфика студенческого творчества состоит в том, что репродукция и творчество находятся здесь в особом отношении друг к другу. Воспроизводящая деятельность характеризуется тем, что всегда завершается созданием продукта уже известного качества. В обучении воспроизводящая деятельность чаще всего ассоциируется только с запоминанием. Вместе с тем репродуктивная деятельность требует как дословного, так и преобразующего воспроизведения. С приобретением преобразующего характера в воспроизводящую деятельность привносятся элементы творчества. В исследовании О.Л. Берак [2] отмечается, что репродукция и творчество выступают как два необходимых, взаимосвязанных, хотя и различающихся элемента целенаправленной деятельности обучаемого. Репродуктивные компоненты деятельности связываются с операционно-технической стороной, со способами деятельности, обусловленными ее предметным содержанием. На наш взгляд, взаимосвязь между продуктивными и репродуктивными процессами находит наиболее полное выражение в творческой деятельности. Открытие новых знаний происходит с опорой на уже имеющиеся знания.
При этом сущность творческой деятельности заключается в возможности отказаться от стереотипного способа действия и выделить до того не воспринимаемые свойства и отношения объектов, включить объект в новую систему связей и отношений, установить новые закономерности. К «творческим компонентам» деятельности относятся элементы, тесно связанные с мотивационно-смысловым и ориентировочно-поисковым компонентами в структуре деятельности. Взаимосвязь репродукции и творчества в учебной деятельности проявляется в том, что репродукционная деятельность является условием творческой деятельности, репродукция и творчество представляют собой две взаимосвязанные стороны любого вида преобразующей деятельности.

Осуществление учебно-творческой деятельности предполагает сформированность у обучаемого необходимых умений, способствующих достижению поставленной цели. Учебно-творческая деятельность имеет сложную структуру и требует для своего выполнения специальных умений. В соответствии с этапами процесса обучения выделяем три основные группы умений творческой деятельности:

- прогностические умения (формулировать цели и задачи творческого задания, обобщать знания по изучаемой теме, организовывать логическое осмысление полученной информации, структурировать изучаемый процесс и осуществлять его формализацию);

- исполнительские умения (наглядно представлять решение творческой задачи, «за- 


\section{International Symposium on Education, Psychology and Social Sciences}

щищать» методику и результаты решения творческого задания);

- аналитические умения (работать с аналитической и научно-методической литературой, контролировать свои действия в решении творческого задания, анализировать полученные результаты).

В ходе учебно-творческой деятельности последовательно выявляется ее цель, предмет и средства, последовательность отдельных действий и операций. Структура деятельности студента по овладению умениями творческой деятельности может быть представлена как система, включающая следующие взаимосвязанные компоненты:

1) осознание профессиональной и личной значимости задачи овладения умениями творческой деятельности;

2) целевая установка на овладение $\mathrm{koH}^{-}$ кретными умениями;

3) актуализация знаний, которые лежат в основе формируемых умений;

4) раскрытие содержания каждого умения как определенной совокупности действий и операций, его составляющих, и способов выполнения действий;

5) организация практической деятельности по овладению умениями;

6) контроль за состоянием сформированности умений, учет и оценка результатов деятельности.

Схематически учебно-творческую деятельность студента можно представить в виде логической цепочки: «мотив - план результат» [4].
Формирование учебно-творческой деятельности обучаемых, как подчеркивает П.И. Пидкасистый [5], предполагает учет психологической, теоретической и практической готовности студентов к обучению в высшей школе: соответствующий отбор учебного материала, планирование его объема с учетом сложности и трудоемкости, использование передовых технологий обучения, проверки и оценки знаний, умений и навыков. Учебно-творческая деятельность является мотивирующей основой для перехода от прагматического к познавательному отношению к миру. Это особый тип социально организованных взаимодействий и взаимоотношений между студентами и преподавателем. Coвместная учебная деятельность обеспечивает перестройку всех компонентов структуры индивидуальной познавательной деятельности за счет создания общности целей и способов достижения результата. Заинтересованность, самостоятельность, сознательность и активность студентов в творческой деятельности определяются характером организованности этой деятельности, формами и методами контроля результатов и отношений к ним.

Для формирования ценностных установок студентов на творческую самореализацию в процессе учебной деятельности, как пишет Л.В. Ведерникова [3], необходимо гуманизировать отношения студентов и преподавателей; преобразовывать традиционные формы учебной деятельности и актуализировать инновационные формы обучения; стимулировать самообразование студентов, включая их в исследова- 


\section{International Symposium on Education, Psychology and Social Sciences}

тельскую работу. Как подчеркивает П.И. Пидкасистый [5], организация учебной деятельности несет в себе ярко выраженную функцию управления. При этом возникает необходимость четкой постановки учебно-познавательной задачи, что дает возможность преподавателю заранее предусмотреть характер деятельности студента и, соответственно, управлять этим процесCOM.

Процесс преобразования и усовершенствования современной педагогической системы, предполагает поиск новых идей, подходов, технологий, форм и методов организации учебного процесса в вузе с целью профессионально-творческого саморазвития субъектов на основе их внутренних мотивов, системы ценностей и профессиональных целей [1]. Креативная дидактика позволяет кардинально изменить образовательный процесс: обучаемый переходит из ранга объекта педагогического воздействия в ранг субъекта творчества, а традиционный учебный материал, из ранга предмета освоения переводится в ранг средства достижения некоторой созидательной цели. Такой способ обучения открывает новые грани научного познания, позволяет повысить степень заинтересованности и уровень мотивации студента, способствует развитию творческих способностей. Учебно-познавательная деятельность это не только канал формирования профессиональных знаний и умений, но и средство развития интересов к познанию и практической деятельности, на основании этого, в конечном счете, определяется уровень и качество подготовленности специалиста [6].

\section{Список литературы}

1. Афонина Р.Н. Культурно-антропологическая направленность тенденций обновления высшего профессионального образования /Р.Н.Афонина // Новые образовательные технологии в вузе. 2014. с 108-119.

2. Берак, О.Л. Соотношение репродуктивных и творческих компонентов учебно-профессиональной деятельности при формировании специалистов в высшей школе: автореф. дис. ... канд. пед. наук / О.Л. Берак. 1985. - 17 с.

3. Ведерникова, Л.И. Формирование ценностных установок студента на творческую самореализацию [Текст] / Л.И Ведерникова. // Педагогика. - 2003. - №8. - C.47- 53 .

4. Ильясов, И.И. Структура процесса учения / И.И. Ильясов. - М.: МГУ, 1986. 198 c.

5. Пидкасистый, П.И. Требования, предъявляемые к обучающимся в вузах / П.И. Пидкасистый // Педагогика. - 2005.- № 3.- C. $47-52$.

6. Afonina R. The problem statement of projecting of pedagogical system of the science education in the liberal arts university / R Afonina // Innovations in education / ed. by I. Kaufer. - Vienna, 2015. - P. 110-137. 


\section{International Symposium on Education, Psychology and Social Sciences}

\section{The text of the article in English}

We consider creative activity primarily as one of the types of educational and cognitive activity aimed at developing contradictions in the course of solving a creative problem, which requires objective and subjective conditions, and the result has novelty, originality, personal and social significance.

The specificity of student creativity is that reproduction and creativity are here in a special relationship to each other. Reproduction activity is characterized by the fact that it always ends with the creation of a product of already known quality. In learning, reproductive activity is most often associated only with memorization. At the same time, reproductive activity requires both verbatim and transformative reproduction. With the acquisition of a transformative character, elements of creativity are introduced into the reproduction activity. In the study of O.L. Berack [2] noted that reproduction and creativity act as two necessary, interrelated, although differing elements of the learner's focused activity. The reproductive components of activity are associated with the operational and technical side, with the methods of activity, due to its subject content. In our opinion, the relationship between productive and reproductive processes is most fully expressed in creative activity. The discovery of new knowledge is based on existing knowledge. At the same time, the essence of creative activity lies in the ability to abandon the stereotypical mode of action and highlight previously unappreciable properties and relations of objects, include the object in a new system of connections and relations, establish new laws. The "creative components» of an activity include elements that are closely related to the motivational-semantic and orientationalsearch components in the structure of activity. The interconnection of reproduction and creativity in educational activity is manifested in the fact that reproduction is a condition for creative activity, reproduction and creativity are two interconnected sides of any type of transformative activity.

The implementation of educational and creative activities involves the formation of the learner necessary skills that contribute to the achievement of the goal. Educational and creative activity has a complex structure and requires special skills for its implementation. In accordance with the stages of the learning process, we distinguish three main groups of skills of creative activity:

- prognostic skills (to formulate goals and objectives of a creative task, to generalize knowledge on the topic being studied, to organize a logical understanding of the information received, to structure the studied process and to formalize it);

- performing skills (to visualize the solution of a creative task, to "protect" the methodology and results of solving a creative task);

- analytical skills (to work with analytical and scientific-methodological literature, to control their actions in solving a creative task, to analyze the results).

In the course of educational and creative activity, its purpose, subject and means, the sequence of individual actions and operations are subsequently revealed. The structure of the student's activity in mastering the 


\section{International Symposium on Education, Psychology and Social Sciences}

skills of creative activity can be represented as a system that includes the following interconnected components:

1) awareness of the professional and personal significance of the task of mastering the skills of creative activity;

2) target setting for mastering specific skills;

3) updating the knowledge that underlies the formed skills;

4) disclosure of the content of each skill as a specific set of actions and operations, its components, and methods of performing actions;

5) the organization of practical activities for mastering skills;

6) monitoring the state of formation of skills, accounting and evaluation of performance.

The student's educational and creative activity can be represented in the form of a logical chain: "motive - plan - result" [4].

The formation of educational and creative activities of trainees, as emphasized by P.I. Pidkasisty [5], involves taking into account the psychological, theoretical and practical readiness of students to study at a higher school: appropriate selection of educational material, planning of its volume taking into account complexity and laboriousness, use of advanced training technologies, testing and evaluation of knowledge, skills. Educational and creative activity is a motivating basis for the transition from a pragmatic to a cognitive attitude to the world. This is a special type of socially organized interactions and relationships between students and the teacher. Joint educational activity provides the restructuring of all components of the structure of individual cognitive activity by creating a common goal and ways to achieve results. The interest, independence, consciousness and activity of students in creative activities are determined by the nature of the organization of this activity, by the forms and methods of monitoring the results and attitudes towards them.

For the formation of value attitudes of students on creative self-realization in the process of educational activity, as L.V. Vedernikova [3], it is necessary to humanize the relations of students and teachers; transform traditional forms of educational activity and update innovative forms of learning; stimulate students' self-education, including them in research work. As emphasized by P.I. Pidkasisty [5], the organization of educational activity carries a pronounced management function. In this case, there is a need for a clear statement of the educational and cognitive task, which allows the teacher to foresee the nature of the student's activities and, accordingly, manage this process.

The process of transformation and improvement of the modern pedagogical system involves the search for new ideas, approaches, technologies, forms and methods of organizing the educational process at the university with the goal of professionallycreative self-development of subjects based on their internal motives, value system and professional goals [1]. Creative didactics allows you to radically change the educational process: the student moves from the rank of the object of pedagogical influence to the rank of the subject of creativity, and traditional 
International Symposium on Education, Psychology and Social Sciences

educational material, from the rank of the subject of development, is transferred to the rank of means of achieving some creative goal. This type of training opens up new facets of scientific knowledge, allows you to increase the degree of interest and the level of motivation of the student, contributes to the development of creative abilities. Educational and cognitive activity is not only a channel for the formation of professional knowledge and skills, but also a means of developing interests in knowledge and practical activity, on the basis of this, ultimately, the level and quality of specialist training is determined [6]. 


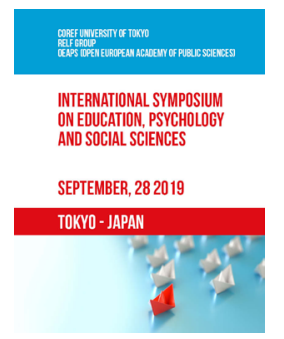

病棟保育士が経験する

道徳的問題に関する質的検討

Experienced by ward nursery teachers

Qualitative examination of moral problems

石井 悠 ( 東京大学大学院 教育学研究科・日本学術振興会)

Atsushi Ishii (Graduate School of Education, The Japan Society for the Promotion of Science)

医療職においては、古くから道徳的問題が議論されてきた。特に看護師に関しては、入院患者に近い ということ

や医師と患者の間で板挟みになりやすいというその性質上、特に道徳的な問題に多く直面する職種と して (Redman, \& Fry, 2000 )、注目を集めてきた背景がある。しかし、入院する子どもの成長発達 を促進する存在として注目され、看護師と同樣に、患者に近く、他職種との板挟みになりやすい病棟 で働く保育士 (以下、病棟保育士) に関しては、このような議論は筆者の知る限り行われていない。 しかし、道徳的問題を経験することが精神的苦痛やバーンアウトにつながることが報告されている ことなどから、彼らが直面する道徳的問題を明らかにしていくことは喫緊の課題である。そこで本 論においては、病棟保育士が経験する道徳的問題に着目し、今後の研究可能性に関して試論を 試 みた。既存の面接データの再分析の結果、病棟保育士も看護師と同樣に、道徳的問題 (道徳的不確か さ、暮藤、ストレス) を経験していることが示唆された。本論では、病棟保育士から語られた道徳的 問題から、今後の研究可 能性に関して試論を試みる。

キーワード : 病棟保育、医療保育、道徳的問題、倫理的ジレンマ

Medical professions have long been discussed in moral issues. Especially for nurses, it is close to inpatients, and it is easy to get caught between doctors and patients, so as a job that faces many moral problems (Redman, \& Fry, 2000) There is a background that has been collected. However, as a nurse who works in a ward that is close to the patient and easily gets caught between other occupations (hereinafter referred to as a ward childcare worker) There is no such discussion as far as I know. However, it is an urgent task to clarify the moral problems they face because it has been reported that experiencing moral problems leads to mental distress and burnout. Therefore, in this paper, we focused on the moral problems experienced by ward nursery teachers, and tried an essay on future research possibilities. As a result of reanalysis of the existing interview data, it was suggested that ward nursery teachers experienced moral problems (moral uncertainty, conflict, stress) as well as nurses. In this paper, we will attempt an essay on future research possibilities based on moral issues spoken by ward nurses.

Keywords: ward childcare, medical childcare, moral issues, ethical dilemma 
I. はじめに

医療職においては、古くから道徳的問題 が議論されてきた。特に看護師に関して は、入院患者に近いということや医師と 患者の板挟みになりやすいというその性 質上、特に道徳的な問題に多く直面する 職種として

(Redman, \& Fry, 2000 )、注目を集め てきた背景がある。一方で、看護師と同 樣に患者に近く、他職種との板挟みにな りやすい病棟で働く保育士（以下、病棟 保育士とする)に関しては、このような 議論は筆者の知る限り行われていない。 しかし、筆者が違う目的で行なった病棟 保育士に対する面接調査の中では、彼ら が道徳的問題を経験していることを伺わ せる語りが多く聞かれた。そこで本論に おいては、病棟保育士が経験する道徳的 問題に着目し、今後の研究可能性に関し て試論を試みる。

\section{II. 問題·目的}

既述の通り、看護職における道徳的問題 に関しては既に多くの関心が寄せられ、 研究知見も蓄積されている。特に看護倫 理の分野においては、看護師が直面す る道徳的問題に関してJameton ( 1984 ) が提案した 3 つの分類 - 道徳的不確 かさ ( moral uncertainty) と道徳的葛藤 ( moral dilemmas) 、道徳的ストレス ( moral

distress ) - に依拠する形で多くの研究が 積み重ねられてきた。道徳的不確かさと は倫理的問題に直面した

際にもっとも早くにみられる反応とさ れ、看護師が何かが間違っていると感じ たり、最善の行動がわからないと感じた りするときに生じる。そして、倫理的ジ
レンマという言葉でも扱われる道徳的暮 藤 ( 本論では道徳的葛藤とする) とは、 複数の可能性のある解決法が存在する状 況で、そして、それぞれの解決法が道徳 的条件で正当でありうる状況をさす。最 後に道徳的ストレスとは、当事者が道徳 的に正しいと思う行動があるにもかかわ らず、その実行が叶わないときに経験す る身体的・精神的苦痛のことをさす。 看護職を対象とした研究知見からは、道 徳的ストレスの経験頻度と強さがバーン アウトを予測することや (Ohnishi et al., 2010 )、道徳的ストレスを経験して離職 した看護師が調查対象者のうち 15\%にま でのぼることが報告されている ( Corley, Elswick, Gorman, \& Clor, 2001)。ま た、その影響の大きさから、道徳的な葛 藤やストレスを経験していても当事者が きちんと認識できていないことが問題視 されたり ( Pendry,

2007 )、専門職としてのガイドラインや 倫理要綱などで葛藤する価値の対立に方 向性をされたりしている

( Fry \& Johnson, 2008 )。

一方で、保育者においては、道徳的問題 は扱われてきていない。しかし、1954 年 に初めて保育士が小児病棟などで働き始 めて以来 (秋山ほか, 2008 )、2005 年に は全国で 300 以上の医療機関に病棟保育 士が配置されていると報告されており( 長嶋，2006)、小児期に入院する子ども の成長発達を促進する存在として他の医

療者からも注目されている（穂高，2013 )。病院で働く保育士は、彼らも患者の 近くで長く関わり、医師や看護師、患者 の間で板挟みになることが多い職種であ ることから、道徳的問題を経験する機会 は多いと考えられる。特に現時点では、 


\section{International Symposium on Education, Psychology and Social Sciences}

病棟保育士の専門性が十分に確立されて いないために業務内容が定まっていない ことや、そのために医師や看護師の理解 も進んでいない（ e.g. 上出・斎藤，2014 ) という背景から、特に道徳的問題に直 面しやすい状況にあるだろう。また、看 護師が道徳的問題に直面した際、最も 有効だった解決方法として同僚への相談 が挙げられている（岩本・溝部・高波， $2005)$ 。しかし、病棟に配置されている 保育士の人数は少ないことが多く、2005 年に行われた調査でも、病棟に保育士を 配置している病院のうち約半数では、つの病棟に配置されている保育士の人数 が 2 名以下であると報告されている（長 嶋，2006）ことから、病棟保育士は道徳 的問題に直面していても十分に対処・解 決できていない可能性があると推測され る。上述のように、道徳的問題を多く経 験することによりバーンアウトや離職、 仕事のパフォーマンスに影響を及ぼすこ とが明らかになっていることから、病棟 保育士においても、彼らが直面する道徳 的問題を明らかにすることは喫緊の課題 ではないだろうか。

以上より本研究では、病棟保育士が現在 どのような

場面で道徳的不確かさや葛藤、ストレス を経験しているのかを、既存の面接デー タの再分析を行うことで探索的に明らか にすることとした。その上で、病棟保育 士の道徳的問題の研究可能性や必要性に ついて考察を試みる。

\section{III. 方法}

現在、病院で働いており、自ら業務内容 を決めている病棟保育士 15 名を対象に 2016 年に行った半構造化面接で得られた データ 1) を、分析の対象とした。面接
に際しては、事前に研究計画書と同意書 を郵送し、同意してもらった方に対して 実際にお会いした際に再度研究目的や倫 理的配慮について説明し、同意書への署 名をお願いした。尚、本研究は研究者の 在籍大学の倫理審査の承認を受けて実施 したものである。

分析手法としては、逐語的に書き起こ された面接 データの、「日々の業務」

「他職種との関わり」(表 1 参照 ) に 関する語りの中で保育士が道徳的問題 に直面していると考えられる事例（イ ンタビューの中で「困っている」「難 しい」などの言葉を使うなど) を抽出 し、Jameton ( 1984 ) の 3 区分に則って 分類を行なった。また、事例の分類の妥 当性・信頼性を確認するため、心理学を 専攻する大学院生 1 名に事例と分類カテ ゴリを渡し、同様の分類になることを確 認した。

\section{IV. 結果と考察}

分析の結果、15 名中 8 名の病棟保育士 から、上記の定義に当てはまる事例とし て 14 事例抽出され、道徳的不確かさ、暮 藤、ストレスそれぞれについての語りが 得られた (表 2 )。以下では先行研究に おいて強く経験されると報告されている 順 ( Redman \& Fry,

2000 ) に、まずは道徳的ストレスから、 実際の語りを引用しながら病棟保育士が 経験した道徳的問題について考察してい くこととする。

表 1 : インタビュー・ガイド 注：本分析の際に使用・参考にした項目 を抜粋。

表 2 : 病棟保育士の経験する道徳的問題 
International Symposium on Education, Psychology and Social Sciences

道徳的問題の種類 道徳的問題の内容 道徳的不確かさ

ターミナル期の保育

道徳的葛藤

( 倫理的ジレンマ) 遊びの提供者 としての保育士 vs 子どもの成長発達・主 体性安全基地としての保育士 vs 治療の円 滑さ

チーム医療の一員としての保育士（情報 共有) vs 患者・家族との信頼関係

チーム医療の一員としての保育士 (看護 師の指示への対応 ) vs 患者. 家族との信 頼関係子どもの満足感 (遊びへの没頭 ) vs 平等

道徳的ストレス 遊び・経験の保証 vs 医療的二ーズ

1. 道徳的ストレス

道徳的ストレスに関しては、「子どもの 安全」と「平等」に関わる問題と、医療 が最優先される環境で保育を行うことに 伴う道徳的ストレスが語られた。例えば 以下のような語りがある。

ここで保育士は、多くの子どもと「平等 に」遊ぶ時 間を確保してあげたいという 気持ちを持ちながら、子 どもの安全性 の確保を優先する必要があることを理解 し、そのように行動しているためにスト レスを経験している。看護師が遭遇する ジレンマを調査した研究で、体験頻度が 最も多かったジレンマが「患者に十分な 看 護ケアを提供できない看護師の充足状 況」であった ( 水澤, 2009 ) と報告されて いるが、事例 A の問題も同様に、人員不 足が背景にあると考えられる。上述の通 り、病棟に配置されている保育士の人数 は少ないことが多く、保育士を配置して いる病棟の病床数は $20 \sim 49$ 床の病院が
$39 \% 、 50$ ～ 100 床の病院が 28\%である にも関わらず、全体の約半数の病院で、 一つの病棟に配置 されている保育士の人 数が 2 名以下であると報告されている( 長嶋 ，2006)。今回の参加者の中にも、 1 人で、内科病棟と外科病棟の、年齢も 病状も大きく異なる 70 床をみているとい う保育士がいた。この意味では、人 員不 足により病棟保育士が経験する道徳的問 題は、看 護師が経験するものよりも潜在 的には多いのかもしれない。

また次のようなストレスも語られた。

遊びが子どもの成長発達のために重要 で、それを提 供することが正しいことだ と考える一方で、治療優先にもなりうる 病院という環境の中でうまくそれができ ていないことにもどかしさを感じている 事例である。この背景には、そもそも「 子どもの遊び」に関して医 療者との共通 認識が出来ていないという問題があるこ とは自明であろう。看護師の調査におい ても、医師との見解の違いによって様々 な葛藤が生じていることが 示されてきた ( 水澤，2009) が、看護師は医療行為を 行う職種だという点で保育士とは大きな 違いがある。必ずしも医療とは関係のな い「遊び」を提供する保育士と他職種の 間には、より大きな溝があるのかもしれ ない。

2. 道徳的葛藤：病棟保育士の立場や役割 病棟保育士が経験する道徳的葛藤として は、病院で働く医療者という立場をとる べきかどうかに関する葛藤がほとんどで あった。まずは、チーム医療の一員とし ての働き方に、葛藤を経験している語り を示す。

検查・処置で子どもを押さえる事例の背 


\section{International Symposium on Education, Psychology and Social Sciences}

後には、早く処置を終わらせてあげるた めに押さえるべきか、それは看護助手の 仕事だから安易に手伝わないようにする べきかという葛藤が生じている。この保 育士が、処置介助や検査介助を行うこと は保育士の仕事ではないと考えているこ とが伺え、そういった仕事を引き受ける ことによって、保育士が、子どもとの間 に築いた信頼関係が崩れてしまうことを 危惧している。

また、次のような語りがある。

この事例では、保育士が入院してきた子 どもと関わ

り始める時期について、看護師からの指 示通りすぐ

に遊びに入るか、「病院の暮らしにまず 慣れて」から入るか、暮藤を経験してい る。看護師を対象とした研究でも、医師 の指示と自分が正しいと思う行動が食い 違うことによって生じる葛藤は、多く報 告されている

(Cohen \& Erikson, 2006 )。しかし、 事例 C と D に共通して、子どもとの信頼 関係の構築や保育士の安全基地としての 機能や役割に関して、十分に他職種と共 有できていない背景が伺える。

また、道徳的暮藤には次のような事例も ある。

この事例では、「嫌だ」と言っている子 の支援を優先するべきか、遊びを支援 するべきかの間で少しの摇らぎを覚えて いる。このような葛藤を経験する背景に は、病棟保育士としての業務内容が定ま っていないことも ( 上出・斎藤，2014) 大きく影響していると考えられる。事
例 $E$ とも合わせて考えれば、保育士とし ての業務やその方法を、今一度再考する 必要が示されているといえるだろう。

3. 道徳的不確かさ：ターミナル期の保育 今回、道徳的不確かさは 1 つしか聞かれ なかった。

この事例の背景では、チーム医療の一員 として、他職種の期待に沿って母親から 聞いた話を共有するべきか、母親との関 係性を守ることを優先するべきか、とい う価値観が葛藤していると考えられる。 最後に、そもそも病棟保育士は子どもと 遊ぶことを 主な仕事とするべきなのかに ついて、葛藤が聞かれた。

病院で余命を迎える、いわゆるターミナ ル期の子ど ものプライマリー保育士に決 まったこの保育士は、その子のために何 をしてあげられるのか、何をしてあげ る のが最善なのかわからず、不確かさを経 験している。このように明示的に「わか らない」と語った保育士は、今回の面接 では一人だったが、ターミナル期の子の 保 育を通して病棟保育感が変わったとい う語りは多く聞かれた。

\section{$\mathrm{V}$. 総括と展望}

本研究より、自ら業務内容を決める病棟 保育士も、一定の道徳的不確かさや暮 藤、ストレスを経験していることが示唆 されたといえる。以下では、今後研究の 発展が望まれる道徳的問題に触れておき たい。

まず、特に今回の面接データからは、信 頼できる人 としての保育士の立場と医 療機関で働く者として治療 の効率や連 携を重視する立場の間の暮藤が多く聞か 
れた。病院によっても、病棟保育士の位 置付けが異なっ てくることが予想できる ( 上出・斎藤，2014）ため、今後はより 多くの病院に勤務する病棟保育士の道徳 的問題を聞き取る意義があるだろう。ま た、遊びに関する葛藤やストレスも比較 的多く語られている。「遊び」は病棟保 育の専門性を問う際にキーワードとして 抽出 される (上出・斎藤，2014）ことか らも明らかな通り、病棟保育士にとって は非常に重要な問題であるといえる。こ のような重要な問題に関して、道徳的ス トレ スなどを経験し続けることはバーン アウトなどにも繋 がってくると考えられ るため、今後より一層、病棟保育士の遊 びに関わる道徳的問題を明らかにしてい く必要があるだろう。 さらに、ターミナル期の子どもに対する 保育に関して病棟保育士が不確かさを 経験するということも、重要な知見で ある。正解がわからない保育という意味 では、一般的な保育と異なる可能性があ る新生児集中治 療室や虐待を受けている 子どもの保育に関しても、不 確かさが経 験されている可能性がある。先行研究で も、保育士養成の基礎教育だけでは医療 の場で働く上で強 い不安があることが報 告されているが（笹川・宮津・入江・神 垣，2010)、その背景には、このような 道徳的不確かさが存在している可能性も あるだろう。どの ような子どもを対象に 保育する場合に、どのような道 徳的問題 を経験するのか、より詳細な検討が望ま れる。

最後に、本研究は、既存のデータを再分 析したものであったため、病棟保育士が 直面する道徳的問題に関して網羅的に検 討できたとはいえない。しかし、本研究 結果をもって、病棟保育士も道徳的問題
に直面していることは、十分に示すこと ができたと考える。配置病棟や対象とす る子どもの疾患が異なれば、経験する問 題の量や質、また、その対処方法も異な つてくることが十分に予想されるだろ う。また、本研究で対象としていた病棟 保育士は全員、自身で業務内容を決めて いる保育士だったが、例えば看護師から の指示で業務内容が決まる保育士が経験 する道徳的問題は、今回得られている問 題とは質が異なることが予想される。加 えて、本研究で得られた知見は病棟で保 育を行う保育士が直面しているものだっ たが、例えば「平等」の問題などは、保 育する人数が多い一般の保育所の保育士 も直面している問題と考えられる。その 意味では、保

育士における道徳的問題は、病棟の保育 士に限らず、一般の保育所や幼稚園など においても、検討が望まれ るかもしれな い。今後はこういった視点からも、研究 知見が蓄積されることが望まれる。

\section{〈引用文献〉}

秋山真里江・江本リナ・松尾美智子・飯 村直子・西田志穗・筒井真優美 .

(2008). 子どもが入院する病棟の保育士 に関する文献検討，日本小児看護学会誌， 17, 79-85.

Cohen, J. S., \& Erickson, J. M. ( 2006 ) . Ethical dilemmas and moral distress in oncology nursing practice. Clinical Journal of Oncology Nursing, 10, 775-780.

Corley, M. C., Elswick, R. K., Gorman, M., \& Clor, T. ( 2001 ) . Development and evaluation of a moral distress scale. Journal of Advanced Nursing, 33, 250-256.

穂高幸枝 . ( 2013 ) . 看護師がとらえた病 


\section{International Symposium on Education, Psychology and Social Sciences}

棟保育士の専門性とそれをとらえるきっ かけとなった体験．日本小児看護学会誌， 22, 89-96.

岩本幹子・溝部佳代・高波澄子 . ( 2005 ). 大学病院において看護師長が体験する 倫理的問題。看護総合科学研究会誌，8, 3-14.

Jameton, A. ( 1984 ) . Nursing practice: The ethical issues. Engle- wood Cliffs, NJ: Prentice Hall.

上出香波·斎藤政子. (2014). 小児病棟 における保育士の専門性に関する検討 一 医療保育専門士への面接調査を通して一。 保健学研究, 52, 105-115.

水澤久恵。(2009) . 病棟看護師が経験す る倫理的問題の特徵と経験や対処の実態 及びそれらに関する要因. 生命倫理，19, 87-97.

長嶋正巳 . ( 2006 )。医療施設における病 児の心身発達を支援する保育環境に関す る調査研究. 平成17 年度児童関連サービ 又等事業報告書. こども未来財団.

Ohnishi, K., Ohgushi, Y., Nakano, M., Fujii, H., Tanaka, H., Kitaoka, K.,

... Narita, Y. ( 2010 ). Moral distress experienced by psychiatric nurses in Japan. Nursing Ethics, 17, 726-740.

Pendry, P. S. ( 2007 ) . Moral distress: recognizing it to retain nurses. Nursing Economic, 25, 217-221.

Redman, B. K., \& Fry, S. T. ( 2000 ). Nurses'ethical conflicts: what is really known about them? Nursing Ethics, 7, 360-366.

笹川拓也・宮津澄江・ 入江慶太・神垣涁 子. ( 2010). 医療における保育の必要 性と課題。川崎医療短期大学紀要，30, 55-59.

〈注〉
1元の面接データは、自ら業務内容を決め ている病棟保育士 15 名を対象に、彼ら が日常的にどのような保育を行うことを 目指しているのか、そして、どのような 保育ができた時に達成感を感じるのか問 い、病棟保育士の日々の実践に沿った専 門性の定義を試みることを目的とした調 査のために収集したデータである。その 分析の結果として、病棟保育士が抱く目 標・達成感のパターンとして、「子ども の「安心感」を大切にしながら、子ども の「自分の力」の発揮を促す保育」など 5 つあることが示されている。 
International Symposium on Education, Psychology and Social Sciences

\section{The text of the article in English}

\section{Introduction}

In the medical profession, moral issues have been discussed for a long time. In particular, nursesas a type of occupation that faces many moral problemsdue to its closeness to hospitalized patients and the nature of being easily caught between doctors and patients.

have attracted attention(Redman, \& Fry, 2000)There is a background. On the other hand, as for the nursery teacher who works in the ward that is close to the patient and is likely to pinch with other occupations as well as the nurse (hereinafter referred to as ward nursery teacher), such discussion is not conducted as far as the author knows.

- However, many interviews with ward nursery teachers conducted by the author for different purposes were told that they were experiencing moral problems. Therefore, in this paper, we focus on the moral problems experienced by ward nursery teachers and attempt an essay on future research possibilities.

\section{Problems / Purposes}

As already mentioned, much attention has already been given to moral issues in nursing, and research knowledge has been accumulated. Especially in the field of nursing ethics, the three categories proposed by Jameton (1984) regarding moral problems faced by nurses: moral uncertainty, moral dilemmas, and moral stress.

Many studies have been accumulated in a manner that relies on distress. Moral uncertainty faced ethical issues

It is the earliest response that occurs when a nurse feels something is wrong or does not know the best action. And moral conflict (also referred to as moral conflict in this paper), which is also treated as an ethical dilemma, is a situation where there are multiple possible solutions, and each solution is a moral condition. A situation that can be justified. Finally, moral stress refers to the physical and mental distress experienced when a party feels morally correct but does not come true.

Based on research findings for nurses, the frequency and intensity of moral stress predicted burnout (Ohnishi et al., 2010), and surveyed by nurses who left moral stress Up to $15 \%$ of subjects have been reported (Corley, Elswick, Gorman, \& Clor, 2001). Also, due to the magnitude of the impact, it has been pointed out that even if they have experienced moral conflicts and stress, the parties have not been able to recognize them properly (Pendry,

2007). Some have been directed by conflicting values

(Fry \& Johnson, 2008).

On the other hand, moral issues have not been dealt with in childcare workers. However, since the first day nursery teachers started working in pediatric wards in 1954 (Akiyama et al., 2008), it was reported that ward nursery teachers were assigned to more than 300 medical institutions nationwide in 2005 (Nagashima). , 2006), other medicalas exists to promote the child's growth and development to be hospitalized during childhood 


\section{International Symposium on Education, Psychology and Social Sciences}

it has been attracting attention from (Hotaka, 2013). Nursery teachers working in hospitals are likely to experience moral problems because they are involved in the vicinity of patients for a long time and are often caught between doctors, nurses, and patients. In particular, at the present time, the specialists of ward nursery teachers are not well-established, so the work content is not fixed, and doctors and nurses are not well understood (eg Kamide, Saito, 2014). From the background, you will be particularly vulnerable to moral problems. When nurses face moral problems, the most effective solution is to consult with colleagues (Iwamoto, Mizobe, Takanami, 2005). However, the number of nursery teachers assigned to wards is often small, and according to a survey conducted in 2005, about half of the hospitals that have nursery teachers assigned to wards are assigned to one ward. It has been reported that the number of nursery teachers is less than 2 (Nagashima, 2006), and ward nursery teachers may not be able to cope with or resolve moral issues sufficiently. Guessed. As mentioned above, it has become clear that having experienced many moral problems has an impact on burnout, job separation, and work performance. Isn't it urgent to clarify?

From the above, in this study, what kind ofward nursery teachers are currently we will explore in an exploratory way by reanalyzing the existing interview datasceneexperiencing moral uncertainty, conflict and stress. did. On that basis, I will consider the possibility of studying the moral problems of ward nursery teachers and their necessity.

III. Method

The data 1) obtained from a semistructured interview conducted in 2016 for 15 ward nurses who are currently working in hospitals and who have decided on their own work were selected for analysis. When interviewing, mail the research plan and consent form in advance, and when you actually meet the person who agreed, explain the purpose of the research and ethical considerations again, and sign the consent form did. This research was conducted with the approval of the ethical review of the researcher's university.

As an analysis method, nursery teachers are faced with moral issues in the narratives of "daily work" and "relationship with other occupations" (see Table 1) of interview data written verbatim. Possible cases (such as using words such as "distressed" or "difficult" in the interview) were extracted and classified according to the three categories of Jameton (1984). In addition, in order to confirm the validity and reliability of the classification of cases, we passed the cases and classification categories to one graduate student majoring in psychology, and confirmed that the classification would be similar.

\section{Results and Discussion}

As a result of analysis, 14 out of 15 ward nursery teachers were extracted as examples that matched the above definition, and narratives about moral uncertainty, conflict, and stress were obtained (Table 2). . In 


\section{International Symposium on Education, Psychology and Social Sciences}

the following, in the order reported to be strongly experienced in previous studies (Redman \& Fry,2000), we first consider moral problems experienced by ward nursery teachers, citing actual narratives from moral stress. Let's go.

Here, the nursery teacher understands that it is necessary to give priority to ensuring the safety of children, while having the desire to ensure time to play with many children "equally". I am experiencing stress because I am acting. In a study investigating the dilemmas encountered by nurses, it was reported that the most experienced dilemma was «the satisfaction of nurses who cannot provide adequate nursing care to patients» (Mizusawa, 2009) However, the problem in case $A$ is also thought to be due to a shortage of personnel. As mentioned above, the number of nursery teachers in the ward is often small, and the number of beds in the ward where nursery teachers are assigned is 39\% for hospitals with 20 to 49 beds and 50 to 100 beds for hospitals. Despite being $28 \%$, it is reported that about half of all hospitals have less than 2 childcare workers in one ward (Nagashima, 2006). Among the participants this time, there was a nursery teacher who was watching 70 beds in the medical ward and the surgical ward that differed greatly in age and medical condition. In this sense, ward nursery teachers may experience potentially more moral problems than those experienced by nurses due to a lack of staff.

The following stress was also spoken.
While play is important for children's growth and development, and providing it is the right thing, I feel frustrated by the fact that it has not been able to do it well in a hospital environment where treatment can be given priority. This is an example. In the background, it is obvious that there is a problem that there is no common awareness with the medical practitioner regarding "children's play" in the first place. Nurses' research has shown that various conflicts have arisen due to differences in views with doctors (Mizusawa, 2009), but nurses are the types of occupations that perform medical practice. There is a big difference. There may be a bigger gap between nursery teachers and other occupations that provide "play" that is not necessarily related to medical care.

2 Moral Conflicts: Positions and Roles Ward Nursery Teachers Most of the moral conflicts experienced by ward nursery teachers were conflicts regarding whether or not they should take the position of medical professionals working in hospitals. First of all, I will tell the story of experiencing conflicts in the way of working as a member of team medicine.

Behind the case of holding a child in an examination / procedure, there is a conflict as to whether it should be held in order to finish the treatment quickly, or whether it should be easily helped because it is a nursing assistant's job. It can be said that this childcare teacher thinks that it is not a childcare worker's job to provide treatment assistance or examination assistance, and undertaking such a job breaks the trust 


\section{International Symposium on Education, Psychology and Social Sciences}

that the childcare worker has established with the child I am worried that it will end up.

There is also the following narrative.

In this case, the nursery teacherinvolved with children who have been about when to start Rihospitalized,as instructed from the or enter into playimmediatelynurse,or enter from the «accustomed first to the living of the hospital», has experienced conflict. There have been many reports of conflicts caused by conflicts between doctors' instructions and behaviors that they think are correct in studies of nurses (Cohen \& Erikson, 2006). However, in both cases $C$ and $D$, it can be seen that the relationship between the building of trust with children and the function and role of childcare teachers as safety bases cannot be sufficiently shared with other occupations.

There are also some examples of moral conflicts:

In this case, there is a slight fluctuation between whether to give priority to the support of a child who says «l don't like» or to support play. The background of experiencing such conflicts is that the details of work as a ward nursery teacher have not been established (Kamide and Saito, 2014), which is considered to have a major influence. When considered together with Case $E$, it can be said that it is necessary to reconsider the work and methods of childcare teachers once again.
3 Moral uncertainty: Childcare during the terminal period

This time, only one moral uncertainty was heard.

In the background of this case, as a member of team medical care, the values of whether to share stories heard from mothers in line with the expectations of other occupations or to prioritize protecting relationships with mothers conflicted. It is thought that. Finally, a question was asked as to whether ward nurses should primarily play with their children.

This nursery teacher, who has decided to become a primary childcare worker for a so-called terminal child who has a life expectancy at the hospital, knows what he can do for that child and what it is best to do Without experiencing uncertainties. There was a lot of talk that nursery teachers who explicitly said "I don't know" were alone during this interview, but that the feeling of childcare in the ward has changed through childcare in the terminal period.

\section{口. Summary and Perspective}

This study suggests that ward nursery teachers who decide on their own work experience certain moral uncertainties, conflicts and stress. In the following, I would like to touch on the moral issues for which future research development is desired.

First, the interview data, in particular, has led to many conflicts between the position of a childcare worker as a reliable person 


\section{International Symposium on Education, Psychology and Social Sciences}

and the position of emphasizing treatment efficiency and collaboration as a person working in a medical institution. It can be expected that the position of ward nursery teachers will differ depending on the hospital (Kamide, Saito, 2014), so it will be meaningful to listen to the moral issues of ward nursery teachers working in more hospitals in the future. . There are also relatively many talks about play-related onflicts and stress. As can be seen from the fact that "play" is extracted as a keyword when asking about the specialty of ward childcare (Kamide and Saito, 2014), it can be said to be a very important issue for ward nursery teachers. Continuing to experience moral stress on these important issues is thought to lead to burnout, etc., so moral issues related to ward nursery play will be further increased in the future. It will be necessary to clarify.

Another important finding is that ward nursery teachers experience uncertainties regarding childcare for children at the terminal stage. In terms of childcare where the correct answer is not known, uncertainty may have been experienced in neonatal intensive care rooms, which may differ from general childcare, and childcare of abused children. In previous research, it was reported that there was strong anxiety about working in the medical field only by basic education for childcare teacher training (Yodogawa, Miyazu, Irie, Kamigaki, 2010). There may be moral uncertainties. It is hoped that a more detailed study will be made on what kind of moral problems will be experienced in the kindergarten children.

Finally, because this study was a reanalysis of existing data, it could not be said that the moral issues faced by ward nurses could be exhaustively examined. However, with the results of this study, we were able to fully demonstrate that ward nursery teachers also face moral problems. It can be fully expected that the amount and quality of the problems experienced and how they will be addressed will vary depending on the ward and the target child's disease. In addition, all ward nursery teachers who were targeted in this study were nursery teachers who decided on their own work content.For example, moral issues experienced by nursery teachers whose work content is determined by instructions from nurses are as follows. It is expected that the quality will be different from the problem that has been obtained. In addition, the knowledge gained in this study was faced by nursery teachers who were raising children in the ward. It seems to be a problem that is faced.

Moral issues related to childcare teachers may be considered not only in ward nursery teachers but also in general daycare centers and kindergartens. It is hoped that research knowledge will be accumulated from this point of view in the future.

Cited References

Mari Akiyama, Rina Emoto, Michiko Matsuo, Naoko limura, Shige Nishida, Masami Tsutsui.(2008). Review of literature on childcare nurses in hospitalized wards. 


\section{International Symposium on Education, Psychology and Social Sciences}

Journal of Japanese Society of Pediatric Nursing, 17, 79-85

Cohen, JS, \& Erickson, T. (2001). Development and evaluation of a moral distress scale. Journal of Advanced Nursing, 33, 250-256.

Yukie Hotaka. (2013). Nurse's specialization of ward nursery teachers and opportunities to capture it The Journal of Japanese Society of Pediatric Nursing, 22, 89-96. Mikiko Iwamoto, Kayo Mizobe, Sumiko Takanami. (2005). Ethical issues experienced by nurses in university hospitals. Journal of Comprehensive Nursing Science, 8, 3-14 Jameton, A. (1984)

Dekoha Masako Saito. (2014). Interviews to study over medical child care professional workers on the expertise of the nursery in the pediatric ward Wotoshite. Health Sciences, 52, 105-115.

Hisae Mizusawa. (2009). Ward Characteristics of ethical problems experienced by nurses, actual conditions of experience and coping, and related factors. Bioethics, 19, 87-97.

Masami Nagashima. (2006). Childcare environment that supports mental and physical development of sick children in medical facilities Research Report on Child-Related ServicesChildren's Future Foundation.

2005.Ohnishi, K., Ohgushi, Y., Nakano, M., Fujii, H., Tanaka, H., Kitaoka, K.,

.. Narita, Y. (2010). Moral distress experienced by psychiatric nurses in Japan. Nursing Ethics, 17, 726-740.

Pendry, PS (2007). Moral distress: recognizing it to retain nurses. Nursing Economic, 25, 217-221
Redman, BK, \& Fry, Takuya Sasakawa Sumie Miyazu Keita Irie-Kogake Akiko. (2010). The need for child care in the medical and challenges. Kawasaki College of Allied Health Professions Bulletin, 30, 55-59. 


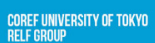

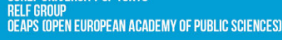

INTERNATIONAL SYMPOSIUM ON EDUCATION, PSYCHOLOGY AND SOCIAL SCIENCES

SEPTEMBER, 282019

TOKYO - JAPAN

\section{Akhmetova Elmira Tursinovna}

Almaty University of Power Engineering and Telecommunications named after G. Daukeev, Senior lecturer, Department for Language Studies

\section{Erzhanova Zhanna Borisovna}

Almaty University of Power Engineering and Telecommunications named after G. Daukeev, Senior lecturer, Department for Language Studies

jeunne15@mail.ru

Annotation: This article discusses the main factors and forms that determine the importance of independent work of students - as one of the forms of academic work in the credit system of education. It also emphasizes independent student's work, as the most important form of training in the preparation of bachelors. Basic factors that form research work of students making their work one of the forms of credit system of studying.

Key words: self-improvement and self-training, navigator character, consciousness and motivation of actions, mobility, ability to predict a situation, active influence. 


\section{International Symposium on Education, Psychology and Social Sciences}

The credit system of education significantly changes the work of both the teacher and the student, putting them before the need for continuous self-improvement and self-training, providing, above all, the higher quality significance of students' independent work. Independence as a special quality of a person includes consciousness and motivation of actions, non-adherence to other people's influences and suggestions, manifestation of one's will, based on an understanding of the need to act and act in these circumstances in accordance with the decision made and the person's internal position. Independent work along with the classroom is one of the forms of the educational process and is its essential component. For its successful organization and implementation, planning and control by the teacher, as well as planning the volume of independent work of the department, are necessary.

The main goal of independent work is not only consolidation, expansion and deepening of acquired knowledge, skills, but also independent study and assimilation of new materials without outside help. Factors determining the importance of students' independent work. Firstly, independent work allows students to delve deeply into the essence of the issue being studied, to thoroughly understand it. Secondly, independent educational work develops persistent ideological views and beliefs in students. Thirdly, in the course of independent work, students form such valuable qualities as industriousness, organization, initiative, willpower, discipline, a creative approach to business, and independent thinking.

Currently, two generally accepted forms of independent work prevail. Traditional, i.e. performed by the student independently in an arbitrary time regime at hours convenient for him, often outside the audience, and when the specifics of the discipline require it, in a computer class. Classroom independent work under the supervision of a teacher, who can be consulted during the course of the assignment. Independent work always causes students, especially in the first years, a number of difficulties caused by the need to adapt former students to new forms of learning.

The main role in the organization of the student's independent work is played by the teacher. The teacher's activities should be aimed at creating conditions for the student to consciously choose the "educational trajectory," helping the student plan his activities, advising on the use of specific textbooks, tools, techniques and teaching methods, and activating the student's cognitive independent activity. In the first lesson, it is important to identify with the student the necessary independent work skills in order to form and improve his various learning activities skills.

The main difficulty is associated with the need for independent organization of their work. Many first-year students experience difficulties associated with a lack of analysis, taking notes, working with primary sources, the ability to clearly and clearly state their thoughts, plan their time, take 


\section{International Symposium on Education, Psychology and Social Sciences}

into account the individual characteristics of their mental activity and physiological capabilities, ignorance of the general rules for organizing independent work. One of the listed tasks of working with freshmen is the development and implementation of methods for rationalizing and optimizing independent work.

Conditionally independent work of students can be divided into compulsory and controlled. Mandatory independent work provides the student with training for the current classroom studies. The results of this preparation are manifested in the student's activity in the classroom and in the quality level of the reports made, tests performed, test tasks and other forms of current control. DAC can be divided into: - the work included in the plan of independent work of each student without fail; - for work included in the plan of independent work of the student's choice. Organizational measures that ensure the normal functioning of the student's independent work should be based on the following prerequisites: - independent work should be specific in its subject area; independent work should be accompanied by effective, continuous monitoring and evaluation of its results. The substantive and substantive independent work of students is determined by the educational standard, work programs of academic disciplines, the content of textbooks, teaching aids and methodological manuals. Control of independent work and assessment of its results is organized as a unity of two forms: - self-control and self-esteem of the student; - control and evaluation by teachers, state examination and certification committees, state inspections, etc. Specific ways of independent work are chosen by the student, and, if necessary, by agreement with the teacher (teachers) within the limits (conditions) established by current regulatory documents.

Any independent work of students should begin with a certain attitude that prepares the perception of the necessary material. The main means of formation of the installation is the verbal instruction of the teacher. Given the characteristics of first-year students, the teacher should use appropriate methods and techniques when organizing students' independent work. First of all, the teacher must teach freshmen: the basics of independent work with the book; note taking; preparation of messages, reports, essays; methods of self-regulation, etc. The leadership of the independent work of students by the teacher should gradually move to selfmanagement and self-organization of the student as a subject of the learning process. For effective and full-fledged independent work, it is necessary that students show activity, intellectual initiative, i.e. tried to find non-standard approaches to activity. Observations of the process of organizing independent work show that positive results can be achieved with any style of pedagogical leadership.

If, under one leadership style, students are given clear instructions and requirements for the work to be done, strict deadlines 


\section{International Symposium on Education, Psychology and Social Sciences}

are set for it and strict control is exercised, then, on the other hand, students will be able to independently choose not only the topic for implementation, but also the nature of the assignment: essay, reports, oral form of delivery, organization of a round table, debates, scientific projects. Students themselves allocate their time and deadline in agreement with the teacher.

Forms of CDS control: oral interview, report, abstract, independent research, supervision (supervision is the cooperation of two professionals (more experienced and less experienced, or equal in experience), during which the specialist can describe and analyze his work in confidentiality; more an experienced person helps a less experienced person to become better with regard to the subject of their work), a colloquium (a form of testing and evaluating students' knowledge in the educational system, mainly in universities. This is a mid-term mini-exam designed to reduce the list of topics for the main exam. Students can also review projects, abstracts, and other written work in the colloquium. Grades obtained at the colloquium can affect grades in the main exam (in different universities, different rules have been adopted on this subject)), test, test.

Information resources of the Internet are used in the educational process for the preparation of essays, reports, the selection of material for term papers and dissertations, and the collection of information on achievements in science and technology. In order to navigate in the variety of information provided by the Internet, methodological recommendations for students have been developed to ensure a competent search and selection of information. It should be noted that Internet sources must be approached with caution, as no one bears responsibility for the information posted.

To provide the material collected by the student, computer presentations are used that allow you to present information in the form of diagrams, charts, graphic compositions. A computer presentation is a certain logical sequence of displaying materials that reveal a stated topic with a high degree of perception.

The greatest effect is achieved with the integrated use of various interactive forms of conducting classes: holding a round table using the «Internet review» for preparing messages and a computer presentation of the material presented.

A computer presentation can be considered as a new form of students' knowledge control, revealing their analytical thinking, the ability to compare the knowledge gained, modeling the work performed in such a way that it is truly creative.

Having considered independent work in some of its aspects, we can draw the following conclusions.

In the process of independent work, individual characteristics of students are clearly manifested: synthetics and analytic perception; stability, distribution and 


\section{International Symposium on Education, Psychology and Social Sciences}

switching attention; speed of memorization, flexibility of thinking, independence and imitation. The role of the teacher in the organization of independent work is very large in the first courses in the preparation of bachelors, then there is a transition of students' self-organization as subjects of learning. In this regard, we can note the conditions that ensure the successful implementation of independent work: motivation of the training task; clear statement of cognitive tasks; method of doing work, student knowledge of how to do it; clear implementation by the teacher of reporting forms, the amount of work, the timing of its submission; determination of the types of consultation assistance; criteria for assessment, reporting, etc. types and forms of control. Conclusion Since independent work is the most important form of the educational process, students should focus on its direct impact, on the formation of such parameters of qualification characteristics as mobility, the ability to predict the situation and actively influence it, independence of assessments, etc. so that students see the positive results of their work.

Many years of experience[3] of working at the University shows that students of technical specialties for the most part do not have the set of knowledge and skills that is necessary for professionally-oriented foreign language teaching. Because of child psychology in high school, students come to the false conclusion that they are not given it, it is not interesting or essential for their personal and career growth.
List of literature:

1. Abdygaporova SB and other Fundamentals of the credit system of education in Kazakhstan. - Almaty: Kazakh University, 2004. - 198p.

2. Erastov N.P. The technique of independent work.-M.-1985.

3.Zhusanbaeva

G. Өzdikzhmystardaytiimdiədister // Қазақ тілі және әдебиеті.- №1.-2001ж.

4. On the independent work of students // VVO.- №1.-1990.-p.63

5. Zagvyazinsky, V.I. Learning Theory: Modern Interpretation: Textbook. allowance for students. higher textbook. institutions / V.I. Zagvyazinsky. - M.: Academy, 2007 .-$192 \mathrm{p}$.

6. The credit system of education and distance learning: problems of the organization of the educational process: Sat. scientific. - Karaganda: Publishing house «Doszhan», LLP «Kent-LTD», 2007. 267 p. 


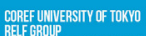

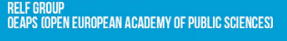

INTERNATIONAL SYMPOSIUM ON EDUCATION, PSYCHOLOGY AND SOCIAL SCIENCES

\section{The relevance of language learning in higher education institutions}

SEPTEMBER, 282019

TOKYO - JAPAN

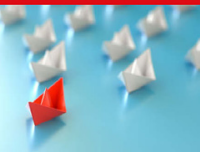

Akhmetova Elmira Tursinovna

Almaty University of Power Engineering and Telecommunications named after

G. Daukeev, Senior lecturer, Department for Language Studies

jeunne15@mail.ru

Annotation: This article addresses the issue of teaching the state language in the field of education. Learning at the language level allows language learners to build their communication skills in the field of general, business and professional communication at sufficient basic standard levels.

Key words: three language policy, vocational training, business communication, terminology, unification of professional terms. 
The final result of learning and language acquisition in higher education institutions is directly related to the quality of the educational complex.

Language is a means of communication that implements the daily and social life of all ethnic groups living in our country. Currently, various textbooks and teaching aids for the study of the Kazakh language are being developed. Everything on every level of modern training of specialists is one of the most important tasks for teachers.

In the Program for the Functioning and Development of Languages of the President of the Republic of Kazakhstan: "The development of the language is one of the most relevant areas of state policy of the Republic of Kazakhstan," and you need to pay attention to the quantity and quality of teaching the state language. President Nursultan Nazarbayev: "The future of Kazakhstan is in the Kazakh language.» Millions of years have passed through the continuation of the human race. The future star is reading. "The day of the public is dark, and the future is foggy", M. Dulatov said. The support of our sovereign state is an education with a high level of education. Just as the anhydrous, dry, shady layer does not grow on the ground, our young generation does not grow and does not grow. The spiritual and social level of any state is evaluated based on the level of education of the people living there.

It is well known that the policy knowing three languages of our country gives priority to the functioning of the state language. Thus, knowledge of the state language by a multilingual person not only improves qualifications, but also contributes to the development of the Kazakh language of science, the official language of business communication, the linguistic intellectual potential of society, the formation and development of human capital in the country.

Today, the expansion of the state language in society is an important part of state policy. Accordingly, the main directions of the state language policy and the main goals of its implementation are determined.

One of them is the expansion of public training courses for civil servants and the introduction of new training technologies in practice. A specialist in all spheres of the country's social and social sphere, a citizen of Kazakhstan, fluent in the state language, should be able to express his opinion in the Kazakh language in any sphere of life, professionally. In this regard, accelerated teaching of the state language is currently developing and its educational and methodological complex is developing. The purpose of aligning the state language is to bring the study of the state language to international standards of European standards.

The state language training course is aimed at increasing the level of literacy and literacy of the Kazakh-speaking population in the field of professionalism, production, and the scientific environment. In practice, language level training includes a basic standard level. As a result of diagnostic tests 


\section{International Symposium on Education, Psychology and Social Sciences}

and a personal interview for knowledge of the state language, students are divided into five levels. The state multi-level training system is conducted in accordance with the national standard of the Republic of Kazakhstan using a two-level approach.

The educational program of the level is developed taking into account the requirements for knowledge of the state language. For example, the initial $\mathrm{A} 1$ and A2 levels are grammatical and lexical materials in the curriculum of the program, as well as four different speech exercises: the work necessary to further increase the level of knowledge, listening and speaking skills, pronunciation, reading, subscribing to students (phrase with phrase, dialogue suggestions, text assembly, etc.).

According to level B1, the course focuses on a specific aspect of the speech language, i.e. scientific work and articles, the science of learning. This is characteristic of abstract words, as well as scientific terminology, complex sentences, sentences, scientific journalistic style and writing the language. The Kazakh language level at this level develops skills and abilities, such as focusing on academic responsibilities, analysis and critical thinking, as well as further improving language skills in four different speech relationships. Course Level B1 includes the following main sections:

Reading - reading, partial reading and attentive reading, critical thinking; read, write, publish, summarize, generalize or write essays in the Kazakh language and develop skills and abilities, such as finding information, access to relevant information and its generalization. Listening is a comprehensive development of competencies, such as listening to lectures, listening and listening to information and summarizing the information necessary to achieve the goal. Writing is designed to develop language and writing skills, such as writing a game, writing a text, writing an essay, presenting and writing an article.

Speech - participation in seminars and business meetings that ensure the comprehensive development of competencies, such as presentations or presentations on academic and professional topics, interpretation, discussion in debates, development of skills to distinguish vocabulary level B1 and distinguish a special vocabulary in context. It aims to expand the vocabulary by mastering special scientific vocabulary and terminology in the study of various scientific works. The main objectives of the course are the study of the oral and written language of students from an academic point of view, the synthesis of educational material, the search for the necessary literature on the subject, reading and understanding of scientific texts, teaching content and teaching content.

At B2 level, a competent competence is developed, such as preparing, conducting, presenting business correspondence, business correspondence, conclusion of contracts and other business-related business documents necessary for business communication in the Kazakh language. In 
this course, students will be able to master business terminology, improve skills and knowledge about the correct writing of documents and business documents, as well as the correct language of speech. This course also focuses on writing skills, writing skills and writing skills in the state language. Such intensive efforts to organize teaching the state language in the republic raise questions about the need to create a rational educational-methodical complex for educational-methodical.

In the article we will discuss the content of the educational complex, which is the basis of the system of equalization of the state language. Thus, the real task is to determine the content of the new language and develop a model of its educational and methodological complex.

The end result of teaching and learning the state language with a system of levels is directly related to the quality of the educational complex. The content of the content provided by the language learner in the state language will be reflected in the educational complex. The system of teaching materials for a multilevel system of teaching the state language includes a basic textbook, study guide, teaching aid, and audiovisual materials. And they must be performed in accordance with the requirements of each level (simple, basic, medium, medium, high, advanced).

The quality of the training complex depends on the methodological skills of its developers. However, nevertheless, experienced methodologists themselves must be guided by the principles of scientific law, the criteria, rules adopted in the world methodology. In addition, the teaching materials should take into account the degree to which language training, the purpose, method of its use and for whom. And in accordance with changes in society, its content should always be updated, supplemented and modified. Now the question arises: what is the main content of pedagogical and linguistic work, as well as the content and structure of the educational complex, which is the main source of educational information? Firstly, it helps the student to master the state language, and secondly, it's spiritual and cognitive advantages. In particular, the role and place of the training complex based on the level of the education system in the educational process must meet the following conditions: flexibility, regularity, continuity, clarity, effectiveness, relevance and clarity. The state language training course is aimed at increasing the level of literacy and literacy of the Kazakh-speaking population in the field of professionalism, production, and the scientific environment. In practice, language level training includes a basic standard level.

As a result of diagnostic tests and a personal interview for knowledge of the state language, students are divided into five levels. A multi-level system of learning the state language is carried out in accordance with the national standard of the Republic of Kazakhstan using a multilevel approach. 


\section{International Symposium on Education, Psychology and Social Sciences}

Currently, the country's industrialization is developing dynamically. One of the pressing issues is the expansion of the use of the Kazakh dictionary in production in this area: preparation of a multimedia program for the training of specialists in the state language in technical fields and technologies; development of an automated document management system and language of documents in the state language with the aim of further increasing the activity of e-government in the country; multilingual dictionaries of translated dictionaries are compiled and published in order to unify professional terms in enterprises and enterprises of the country. In the field of education, new thinking, new relationships, new prospects are being formed, it is impossible to become a competent and versatile specialist until they appear in the field of advanced education technologies. The acquisition of new technology will have a profound effect on the formation of the intellectual, professional, moral, spiritual identity of the teacher and help organize the process of self-development. The effectiveness of new pedagogical technologies differs from traditional teaching: teacher productivity increases; work at the level of each student; increasing interest in the subject; student work is evaluated objectively; develops personal qualities of thinking, memory and thinking of students.

Our task is to choose an effective learning technology that will provide self-education and the formation of a person who can apply the knowledge gained in different life situations. When studying the Kazakh language, the teacher should first of all be interested in the interests of the student. Secondly, it is necessary to explain the language needs in life. Having studied this requirement, an interested student knows the language well.

Summing up the above, the development of the Kazakh language is one of the most important issues of teaching the Kazakh language, education and upbringing. Thanks to this, it is possible to create a culture of creative and competent language, to teach the younger generation a deeper understanding of the origin and secrets of their native language.

Teachers find the student's characteristics in the search for language development and take into account the complex and complex issues of work. Particular attention is paid to the fact that an important part of language development is beautiful and competent. In addition to writing culture, writing culture literacy is an integral part of language development. 


\section{International Symposium on Education, Psychology and Social Sciences}

List of literature:

1. K. Kadysheva «Scientific and methodological bases of modern up-todate teaching: Kazakh language in another language» 2014

2. N. Oralbaeva, K. Zhaksylykova «Methods of teaching Kazakh language in Russian schools» 2010

3. Karayev. JA, Kobdikova Zh.U. Actual problems of modernization of the pedagogical system on the basis of technological approach. A: 2005.34 p.

4. Kuanyshbayeva A. The use of newest technological methods: Kazakh language: Methodology. Republican scientificmethodical magazine, №2, 2004. 47 p. 
conferuyeEsiry of ToNvo

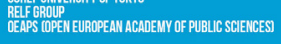

INTERNATIONAL SYMPOSIUM ON EDUCATION, PSYCHOLOGY AND SOCIAL SCIENCES

\section{New techniques and methods in foreign language}

SEPTEMBER, 282019

TOKYO - JAPAN

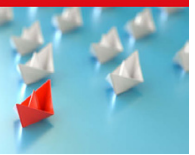

Raiymkul Zarina Abdikamalkyzy

Almaty University of Power Engineering and Telecommunications

named after $G$. Daukeev,

Senior lecturer, Department for Language Studies

jeunne15@mail.ru

Annotation: We have considered the main approaches and methods of FLT as models or paradigms of theory, research and school practice. All of methods of teaching English language have introduced innovations at a given moment, superimposing on the former ones in an eclectic way. The implementation of innovative methods in teaching is an essential prerequisite in solving educational problems. Constantly evolving system of information management in combination with technical support provides the highest quality of educational process.

Key words: methods, approaches, project based learning, task based learning, communicative methods. 
The changing realities of the modern world require the same changes in educational systems. Therefore, the topic of innovation is becoming important for the entire system of education and teaching a foreign language, in particular. Unfortunately, the educational system at this stage takes a "catching up position" [1] in relation to economics, engineering, and technology, although education should predict the future activities of a specialist and prepare him for this activity.

"Under the technology you need to understand the totality and sequence of methods and processes for the conversion of raw materials, allowing obtain products with specified parameters" [2]. Under the pedagogical technologies of teaching a foreign language in a non-linguistic university should understand the way of planning and implementing language training specialist for effective work. An analysis of the existing literature allows us to define the concept of "innovation" as applied to the process of teaching a foreign language as: the use of foreign experience and its extrapolation to the educational environment; the use of traditional scientifically based techniques of the past in modern conditions; the creation of completely new pedagogical teaching technologies. The following innovative technologies are used in foreign language teaching: binary lesson, project, distance learning, training in collaboration, multilevel training.

Its seems worthwhile, first of all, to clarify briefly the concepts of approach or principles, method and technique, which are mutually and hierarchically related. They represent, in fact, three levels of analysis and teacher's decision making for teaching and learning English in the classroom. An approach or strategy is the most abstract of all three concepts and refers to the linguistic, psycho- and sociolinguistic principles underlying methods and techniques. Actually, every teacher has some kind of theoretical principles which function as a frame for their ideas of methods and techniques. A technique is, on the other hand, the narrowest of all three; it is just one single procedure to use in the classroom. Methods are between approaches and techniques, just the mediator between theory (the approach) and classroom practice. Some methods can share a number of techniques and, though some techniques have developed autonomously, the most important ones start from the main methods. Now it seems appropriate to mention the three major language learning issues that language pedagogy and ELT have dealt with through this century and that always concern researchers and the teaching profession. Stern (1983:401-5) labels them as follows: 1. The L1-L2 connection, that is, the disparity in the learner's mind between the inevitable dominance of the mother tongue and the weaknesses of the second language knowledge. 2. The explicit-implicit option, that is, the chose between more conscious ways of learning a foreign language and more subconscious or automatic ways of learning it. This issue remains to a great extent unresolved and has very often 


\section{International Symposium on Education, Psychology and Social Sciences}

posed a dilemma to the FLT profession and research, as, for example, during the debate between cognitivism and audiolingual approaches in the 60s, and later on with Krashen's Monitor Theory, which makes a distinction between language learning (explicit and conscious) and language acquisition (implicit and subconscious). 3. The code-communication dilemma has become a major issue recently. It refers to the problems that learners have to cope with when learning a new language, as they have to pay attention on the one hand to linguistic forms (the code) and on the other to real communication.

In this sense methods are considered representations of language knowledge for pedagogical purposes and are part of a paradigm (a unit of theory, research and practice), which means a predominant way of building up theories, doing research and carrying out classroom activities. In fact, FLT methods have appeared as a result of the application of the new theoretical findings. Methods are also conditioned by educational philosophy, approaches about language nature and how it can be taught and learnt, and conceptions about classroom interaction. All this pervaded by those values concerning society and human relationships. When these aspects start to change it can be said that a shift of model is taking place.

The teacher's tasks are to create the conditions for practical language learning for each student, to choose such methods of teaching that would enable every student to show their activity, their creativity, to increase students' cognitive activity in learning foreign languages. The use of modern tools such as computer programs, Internet-based technologies, as well as cooperative learning and project technology can solve these problems [3].

Project method is one of the most pressing contemporary technologies in teaching foreign languages. It combines the elements of problem-based learning and collaborative learning that allows achieving the highest level of mastery of any subject, and foreign language in particular. Project method forms students' communication skills, culture, communication, the ability concisely and audibly formulate thoughts, be tolerant to the opinion of partners in communication and develops the ability to extract information from a variety of sources, to process it with the help of modern technologies. All these factors create language environment that - results in the appearance of the natural need to interact in a foreign language.

Project-based learning does not contradict the traditional ways of learning. It helps to activate students since most of them have an interest for new knowledge. Such kind of motivation - the desire to successfully develop theme of the project - is often stronger than the demands of parents and teachers to study hard in order to get excellent and good marks.

The main purpose of the use of this innovative approach is the ability to 
effectively master students' foreign communicative competence. It includes the following concepts: [4]. Verbal competence is creating an opportunity of manifestation of communicative skills in all forms: listening, speaking, writing, reading, translation within a specific topic; socio-cultural competence is the formation of ideas about the social and cultural specificity of the target language; linguistic competence is students' acquisition of lexical units relating to the topic as a necessary basis for registration of speaking abilities; educational and cognitive competence is the improvement of educational activity on mastering of foreign languages; compensatory competence is formation of skills of overcoming difficult situations in a shortage of linguistic resources.

Also, this approach forms informational competence which manifests the ability to work independently with reference books, find necessary information in various sources, and see links with other branches of knowledge. Moreover, project-based learning contributes to enhancing students' personal confidence, developing a «team spirit» and communication skills; providing a mechanism for critical thinking, the ability to find ways to solve problems and developing students' research skills.

Due to the growth of person's potential, skills and innovations we can apply project technology from the second grade. In my experience, there are many brilliant students, who want to know much more information; and while little children are interested in learning foreign languages we must use all these approaches in order to raise the quality of teaching. In my work I mostly use projects, role-plays and communicate approaches. When we speak about young children the projects can be like «My Family», the creation of a family tree, the story about a weekend day. It should be noted that parents are often involved in creating projects, because collaboration on a joint project results in convergence and communication.

The forms of project can change and become more complex depending on students' age. For instance, in the 6th grade students create a guide to Great Britain. Each of them creates a single page, and then the pages are connected together. The cover of this brochure is trusted to students who can draw well. The teacher explains the purpose of the task to students. They have the right to propose their own project, if none of the suggested ones does not arouse their interest.

The work on the project can be carried out either individually or in groups. Working in groups, the participants of the joint project should distribute the roles and realize that success depends on the contribution of each participant. Project work begins in the classroom as a teacher-supervised activity. Projects may be short-term or long-term. Depending on the type, they can be presented at the next lesson, or at the final lesson. It is important to organize the work using project, creating the most favorable conditions for the disclosure and manifestation of the creative potential 


\section{International Symposium on Education, Psychology and Social Sciences}

of the participants. In my experience, I organize post-project exhibition of the works, so that other students, parents and teachers should be able to see and appreciate the importance of this work.

Using project method in my work, I came to the conclusion that this method is very effective at generalization, consolidation and revision of educational material, especially in the organization of its practical application. For me there is a particularly appealing fact that projectbased learning actively influences the motivation of student. The work with the project - presentation encourages students to use computer technology. It should be noted that many students get their first experience in Power Point preparing for such kind of projects.

Project-based forms both improve the overall culture of communication and social behavior in general and give students the practical language skills.

Project technology allowed students to integrate a variety of activities, making learning enthralling, more interesting and therefore, efficient. Students with different abilities became successful and felt they were needed in the project activities. Educational, social and communication skills were developed during the implementation of projects. [4] At the preparatory stage, students learned how to work with dictionaries, reference books for posts, thought through the way of presentation, and of course learnt to sort out their work. Project-based learning has changed students' attitude to the computer: computer has been transformed into a source of information and one of the ways of presentation the material.

In the last decade there have been important innovations in theory, research and classroom experience, which are introducing sound changes in FLT and represent a challenge to the dominant model. We can say that at the moment two major paradigms coexist: the propositional (structural and functional approaches) and the procedural (task-based and process approaches). We have considered the propositional models above as ways of teaching and learning through formal and systematic statements (expressed as structures, rules, functions...), though they differ in the main element they focus on and in how they sequence the content.

The most important changes and innovations in education refer to (see Breen 1987:157-60): 1) views of language (considered above when dealing with the communicative approach); 2) views of teaching methodology, which recognize the necessary balance between planning objectives and content with close attention to the development of classroom implementation; 3) views of learners' contributions, which consider the process of classroom interaction and context the basis for learning, not the content of a lesson; 4) views of planning, which assume that the teaching-learning process, activities and roles are the significant substance of 
lessons for those who participate in them, instead of the content of lessons. Fig. 6 Changes in ELT These innovations mean a change of emphasis from the subject to be learnt to the learning process and imply interesting consequences of negotiation, evaluation and retrospective planning.

Procedural models exemplify this alterative drawn on these innovations and represent how something is done. They consider linguistic forms and functions as partial aspects of what is to be learnt and regard the task as the central element of learning. The use of tasks tries to achieve some objectives in the target language through a process which will give a result or will solve a problem, as it is usually done in real life. These models have a flexible way of curriculum design, as they take account of a set of goals and plan content and tasks simultaneously, so that content can suggest tasks and vice versa; the results of the evaluation are introduced back into the planning process.

List of literature:

Larsen-freeman, D. 1986. Teaching and Principies in Language Teaching. Oxford: Oxford University Press.

Estaire, S. and J. ZANÓN. 1994. Planning Classwork. A Task-Based Approach. Oxford: Heinemann.

Prabhu, N. 1987. Second Language Pedagogy. Oxford: Oxford University Press. 4. Полат Е.С. Метод проектов на уроках английского языка.// Иностранные языки в школе.-2000.-№2,3-С.17-19,23-24. 


\section{International Symposium on Education, Psychology and Social Sciences}

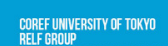

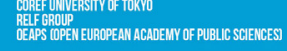

INTERNATIONAL SYMPOSIUM

ON EDUCATION, PSYCHOLOGY

AND SOCIAL SCIENCES

SEPTEMBER, 282019

\section{Corporate governance developments in the saudi arabia and malaysia}

\section{TOKYO - JAPAN}

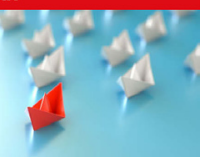

Algoere Turki Naif \& Hasani Mohd Ali

Faculty of Law, The National University of Malaysia

Abstract: In the past few years, there has been an increasing concern over the discrepancy of standards of the corporate governance amongst the developed and the developing countries since they affect their competitive advantages economically. In 2017, Saudi Arabia and Malaysia have amended their codes on corporate governance, in order to promote ethical behaviour, transparency, accountability and investor stewardship. In this paper, the researchers analyse the important features of these new codes of Saudi Arabia and Malaysia. They use a comparative approach to identify the advantages and limitations and also to determine areas for improvement. This paper finds that several transformations were already taking place in both jurisdictions. However, there are many areas that require continuous development, especially those related to the independence of the board, gender diversity problems, and impartiality in the decision- making process. The researchers suggest that many recommendations regarding the manner in which the two countries can address the loopholes and thereafter, improve their corporate governance codes in order to be on a par with international standards.

Keywords: Corporate governance, Investments, Directors' duties, Gender issues. 


\section{International Symposium on Education, Psychology and Social Sciences}

INTRODUCTION

The concept of corporate governance has been recognised since the development of the joint stock companies and was considered an important component of corporate law and practice. These corporate governance systems were developed over many decades to tackle the systemic crises or the corporate failures. In the past few years, there has been an increasing interest in corporate governance amongst the developed or the less developed nations. After the economic collapse and the financial crises affecting many countries like USA, Russia and other countries in Latin America and East Asia, several corporate governance regulations were presented to deal with the restructuring efforts aimed at corporations. ${ }^{1}$ The various collapses and crises were attributed to a lack of investor confidence, inadequate corporate transparency or disclosure and a lack of structured corporate governance. ${ }^{2}$ In addressing these issues, many reform measures had to be carried out to strengthen the existing guidelines and codes regarding corporate governance.

The corporate governance is vital for the economic development and establishment of financial market stability. In the past few years, increasing global financial crises have highlighted the significance of corporate governance. Due to economic liberalisation and globalisation, the corporate governance-related components were considered as an important contemporary tool. 3

Corporate governance needs to be developed further in Saudi Arabia to help the country facing the competitive challenges that can affect the country in the future. There are several rules and regulations that contributed to the development of corporate governance in Saudi Arabia. The development of corporate governance is divided into two stages. The first stage began when the Ministry of Commerce and Industry in 1985 issued the Disclosure and Transparency standard. ${ }^{4}$ This led to the recognition of corporate governance and this disclosure and transparency standard is considered to be one of

1 Demirag, I. \& Solomon, J. (2003). Guest Editorial: Developments in International Corporate Governance and the Impact of Recent e-Events. Corporate Governance: An International Review, 11 (1): 1-7, 1.

2 Ho, S. \& Wong, K. (2001). A Study of the Relationship between Corporate Governance Structures and the Extent of Voluntary Disclosure. Journal of International Accounting, Auditing and Taxation, 10 (2): 139-156, 140.

3 Al-Mutairi, O. (2003). Apply the Procedures Governing the Companies in Saudi Arabia. Arab Journal of Administrative Sciences, Arabic Ed., 15 (3); 1-50, 5.

4 Meteb, M.A. (2012). The Importance of Corporate Governance in Saudi Arabian Economy. Journal of WEl Business and Economics 4 (1): 1-25, 18. 


\section{International Symposium on Education, Psychology and Social Sciences}

the most important elements of corporate governance best practices. 5 The second stage of the development of corporate governance in Saudi Arabia witnessed the enactment of Capital Market Law of 2003 and the issuance of regulations by the Board of the Capital Market Authority established by the Capital Market Law. ${ }^{6}$ The Board of the Capital Market Authority has used the powers given to it and issued regulations regarding corporate governance. The most recent development of corporate governance in Saudi Arabia is the released of Regulations on corporate governance in the year 2006.

The Saudi Arabian government may review and learn lessons from other jurisdictions. In order to remain competitive in the changing economic climate, the Saudi corporations have to implement and adapt the best corporate governance practices for the purpose of fulfilling the arising demands and opportunities. In a similar development, the Malaysian Code on Corporate Governance (MCCG) was amended to reflect the internal standards and universal principles of the Corporate Governance. ${ }^{7}$ Hence, any adherence by these companies to the MCCG would help them remain on par with the international governance standards. ${ }^{8}$ In 2017 , both Malaysia and Saudi Arabia amended their corporate governance codes, for the purpose of promoting accountability, ethical behaviour, transparency and stewardship of the investor capital. Further, these amendments increase the distribution of the responsibilities and rights amongst the participants in a company. They also outline the processes and rules that are needed for controlling, risk-management and decision- making purposes. ${ }^{9}$

In this paper, the researchers discuss the important features of these new codes of the corporate governance in Malaysia and Saudi Arabia. They also attempted to highlight the loopholes and the areas that need further improvements. For this purpose, they overviewed

5 Ibid.

6 Falgi, K. I. (2009). Corporate Governance in Saudi Arabia: A Stakeholder Perspective. Unpublished PhD.UK. University of Dundee and Meteb, M.A. (2012). The Importance of Corporate Governance in Saudi Arabian Economy. Journal of WEl Business and Economics 4 (1): 1-25, 18. 7 Christopher, S. and Ong, L. (2017). The Malaysian Code on Corporate Governance 2017, availableat https://www.christopherleeong.com/media/2803/ clo-2017-05-the-malaysiancode-onf.pdf (accessed 9 April 2018).

8 lbid.

9 Ibid. 


\section{International Symposium on Education, Psychology and Social Sciences}

the corporate governance and also discussed the various theories. Thereafter, they examined the development of the corporate governance in the two jurisdictions and also highlight the provisions in the new codes. Finally, the discussion compares both codes of Malaysia and Saudi Arabia in order to identify their similarities and determine the areas which need further improvement to attain the global corporate governance standards.

\section{AN OVERVIEW OF CORPORATE GOVERNANCE}

The codes on the corporate governance include the regulation of the relationship between the executive directors, board, shareholders and the stakeholders. They also help in establishing the processes and rules which would facilitate decision-making and add further transparency so that the rights of all stakeholders and shareholders could be maintained. This would help in achieving competitiveness, transparency and fairness during the exchange in a business environment. The corporate governance includes the manner in which the company is controlled and directed so that it displays an optimal performance. It also describes the way the board and the management were held accountabletoallowthe shareholders to derive a maximum advantage from the corporate performance. ${ }^{1 \uparrow}$ Towards this end, it is important to display a higher level of transparency in the process of directing or controlling a company, so that the vital corporate information can be reliably disclosed to the potential or existing shareholders. 2 Goo and Carver argued that corporate governance highlights the relationship between all participants since it determines the direction and performance of the corporations. ${ }^{13}$ These basic participants include the management, shareholders, the board of directors along with the employees, suppliers, customers, creditors and the total community. ${ }^{14}$

The corporate governance helps in improving the management and enables a prudent distribution of all company resources, which further

10 Part 1 Preliminary Provision of the Saudi Code on Corporate Governance 2017.

11 Goo S. H. \& Carver, A. (2003). Corporate Governance; The Hong Kong Debate. Asia: Sweet \& Maxwell, 4.

$12 \quad$ Ibid.

13 Ibid.

14 Monks, R. \& Minow, N. (2004). Corporate Governance. Oxford: Blackwell Publishing, 10. 


\section{International Symposium on Education, Psychology and Social Sciences}

improves the corporate performance. All the earnings derived from the management will improve performance and increase the value of the shareholdings. ${ }^{15}$ In contrast, improper corporate governance results in very poor earnings and management, which could affect the share value and lead to the liquidation of the company. ${ }^{16}$ In the presence of ineffective corporate governance activities, the investors tend to withdraw all their savings, which can significantly decrease the share prices and liquidity which caused the whole investment turn unattractive. ${ }^{17}$

The corporate governance provisions describe the significance of the relationship between all shareholders and stakeholder groups, or the board of directors and the top management of different corporations. Hence, the corporation regime offered many considerations for the regulators, related to their effectiveness to the shareholders, local community, employees and the environment. ${ }^{18}$

Based on the practices in the developed and developing countries, there are generally two prevailing views regarding the corporate governance system. A few countries tend to follow the Anglo- American shareholder model while some other countries follow the Continental European and Japanese stakeholder model. ${ }^{19}$

The corporate governance regulations used in Saudi Arabia are based on the Anglo-American shareholder model. Many studies found that corporate governance acts as an important tool to develop and control businesses. Corporate governance includes many principles which are anticipated by the shareholders. This tool encourages a complete disclosure of corporate information, that in turn helps them to deter the wrongdoings committed by the chief executives and the board of directors. While there are many factors contributed

15 Mobius, M. and Chan, D. (2000). Corporate Governance in Hong Kong - Gaps that Need to be Filled" in Chee Keong Low (ed), Financial Markets in Hong Kong. Singapore: Springer, 30. 16 Ibid.

17 Goo S. H. \& Carver, A. (2003). Corporate Governance; The Hong Kong Debate. Asia: Sweet \& Maxwell, 5.

18 Solomon, J. \& Solomon, A. (2004). Corporate Governance and Accountability. England: John Wiley \& Sons, Chichester, 2.

19 Aguilera, R., Williams, C., Conley, J. \& Rupp, D. (2006). Corporate Governance and Social Responsibility: A Comparative Analysis of the UK and the US. Corporate Governance: An International Review, 14(3): 147-158, 149. 


\section{International Symposium on Education, Psychology and Social Sciences}

to the significance of corporate governance, at the same time, the fact that there is a lack of control strategies and adequate regimes in place also have negatively affected the business activities of the global stock markets. 20

Corporate governance is vital for the domestic corporations and is also necessary to prevent further withdrawal of the foreign investment which are vital for the economy and quality of the institutions for governance. 21 There is a lot of discussion regarding what is included in the effective corporate governance and the factors that are necessary to attract additional external investment and to warrant the sustainable development of a country's total economy. Effective corporate governance correlate strongly with corporate performance because: 1) corporate governance encourages additional external investment in the different organisations; 2) it decreases the capital costs; 3 ) it encourages further reforms that can improve the operational performance, and; 4 ) it decreases the risk of contagion from the financial distress. ${ }^{22}$

The disclosure requirements are an effective market-led technique of achieving all the results. The corporations and organisations must present a descriptive and coherent statement which includes all the elements of a corporate governance structure and practice. This statement must also describe the operations of the shareholder meetings and its important powers, the operation and the composition of the board and all other committees, along with a reference to the code on the corporate governance that can be used at the national level, which is complied with by the company or used as a reference to explain if there is a deviation. 23

There is an increasing awareness about the correlation between an effective corporate governance framework and the improving

20 Ibid; El-Khudery. M. (2005). Corporate Governance, Arabic edition. Egypt: Arab Nile Group, 6.

21 El-Khudery. M. (2005). Corporate Governance, Arabic edition. Egypt: Arab Nile Group, 6.

22 Grais, W. \& Pellegrini, M. (2006). Corporate Governance in Institutions Offering Islamic Financial Services: Issues and Options. World Bank Policy Research Working Paper, No. 4052, 7. 23 Bolkestein, F. (2003). Modernising company law and enhancing corporate governance in the EU: The way forward, available at europa.eu/rapid/press-release_SPEECH-03-298_en.doc (accessed 13 April 2018). 


\section{International Symposium on Education, Psychology and Social Sciences}

financial stability. The corporate governance and the financial stability form an indirect relationship, where the companies are not obligated to pursue any financial stability unless the regulations or legislation require it. 24

Additionally, corporate governance is a vital element which helps in achieving economic growth and performance as well as to boost the investors' confidence. Hence, the supporting structures for controlling, determining and fulfilling all corporate targets and objectives must be put in place. It also triggers the creation of appropriate initiatives for the various members of the management and the administrative bodies. ${ }^{25}$ Effective corporate governance in the company and the total economy is vital for the purpose of developing trust and confidence in the existing market economy. 26

Ross observed that the different corporate structures vary in many ways, though the major business goals remain universal. 3 major models are in existence in the current corporations; namely, the continental, Japanese and the Anglo-Saxon, models. 27 Out of these models, the Anglo-Saxon model has been developed in the US and UK, and the major controlling parties in the model include the shareholders and the board of directors. The Chief Officers and the managers possess a secondary authority. ${ }^{28}$ The managers derive their power from the company board, which is theoretically dependent on the approval of the voting shareholders. A majority of the companies that follow the Anglo-Saxon corporate governance system control the shareholders' ability to display a practical and day-to-day control of the company activities. The Anglo markets also display a highly dispersed shareholder and capital structure. 29

The term "continental" refers to central Europe. Ross stated that the continental model was based on the fusion of the fascist and

24 Lupu, L. (2015). The Indirect Relation Between Corporate Governance and Financial Stability. Procedia Economics and Finance, (22): 538-543, 540.

25 Kocmanová1, A., Hrebicek, J. and Docekalova, M. (2011). Corporate Governance and Sustainability. Economics and Management, 16, 2.

26 Ibid.

27 Ross, S. (2015). What are some examples of different corporate governance systems across the world? Available at https://goo.gl/8HTqEr (accessed 22 January 2018).

28 Ibid.

29 Ibid. 


\section{International Symposium on Education, Psychology and Social Sciences}

the Catholic influences seen in the early and mid-20th century. The German and Italian companies have used this model. According to Ross, in a continental model, the company entities are considered to be an organising vehicle between all the various domestic interest groups. Generally, banks play a vital role in the financial and decision- making process of corporations. They offer special protection to the creditors, especially the politically-connected creditors. Such companies consist of a Supervisory Council and an executive board, wherein the Supervisory council manages the executive board that, in turn, controls the company management. The domestic and the government interests severely affect the continental model, and a lot of attention is given to the corporation's responsibility to fulfil the governmental objectives. 30

The $3^{\text {rd }}$ model includes the Japanese model, which displays a sense of mutual balance and responsibility. In Japanese, the term, "balance" refers to the loyalty between the various suppliers and customers. In actual practice, Ross stated that this balance is converted to a type of defensive posturing and a distrust of the newer business relationships compared to the old and existing relationships. The Japanese regulators play a vital role in the corporate policies since the major corporation stakeholders include the Japanese officials. Ross stated that in this model, the Japanese Ministry of Finance and Central Bank reviewed all relationships between the various groups and exhibited a total control over all negotiations. Based on the concentration of the power amongst the Japanese banks and corporations, the Japanese model showed a lack of transparency. The individual investors are perceived to be less important than the government, business entities and the union groups.

Finally, the differences between all the systems are reflected in their different objectives. The Anglo-Saxon model is more oriented towards the stock market, while the remaining two models focused on the banking and the credit markets. The Japanese model is rigid and concentrated whereas the Anglo-Saxon model is more flexible and dispersed.

30 lbid. 


\section{International Symposium on Education, Psychology and Social Sciences}

THE DEVELOPMENT OF THE CORPORATE GOVERNANCE IN SAUDI ARABIA

The Islamic principles as the foundation present within the business environment since they strongly believe in Allah, focus primarily on high ethical standards and protection of human rights. Hence, Saudi Arabia has adopted the majority of their auditing and accounting standards with influences of the Sharia principles. Sharia remains as the supreme law in Saudi Arabia, and the legislators' work is always in accordance with Sharia principles. Hence, rules enforced must not "contravene the spirit of Islamic law". ${ }^{1}$ As mentioned above, corporate governance is vital for any country, including Saudi Arabia. Protection of all rights of the parties is an important aim of the corporate governance, and the Islamic religion supports every process that attempts to fulfil this aim, as long as it does not violate any Sharia principle. Thus, the concept of corporate governance is not strange to the Islam religion. Lewis stated that Islamic corporate governance can be developed using two concepts 32 - 1) Sovereignty of Sharia over the different aspects of life, like the social, economic and legal; and 2) Financial and the Islamic economic principles such as a prohibition of riba (usury) and an imposition of zakat, which can directly affect all policies and practices of the companies and also ensure the implementation of proper business ethics.

In 2006, due to the collapse of the Saudi Exchange, the country had lost about US $\$ 450$ billion. 33 This was a stunning blow to the broad Saudi economy, which showed low inflation and a stable growth. Oil exports form a major proportion of the national income of Saudi Arabia, however, accession to the World Trade Organisation (WTO) helped the country improve its foreign investment and increase the diversification of its economy. 34 The collapse of the Saudi exchange triggered the Saudi regulators to take steps to protect the

31 Al-Haddab, B. \& Puig, G. V. (2013). The Protection of Minority Shareholders in the Gulf Cooperation Council. Journal of Corporate Law Studies, 13.

32 Lewis, M. (2005). Islamic Corporate Governance. Review of Islamic Economics, 5 (9): 5-29, 4.

33 Al-Matari, Y.A., Al-Swidi, A. K. and Fadzil. F. H. (2012). Corporate Governance and Performance of Saudi Arabia Listed Companies. British Journal of Arts and Social Sciences, 9(1): 21-251, 242. 34 Capital Markets Guide. (2008). Middle East: Towards Innovation and Transparency, available at http://www.gtpak.com/Publications/Downloads/ memg_report_final.pdf (accessed 25 March 2018). 


\section{International Symposium on Education, Psychology and Social Sciences}

securities market and investors as an additional precautionary step in anticipation of possible future economic collapses. 35

One of the main steps implemented by the Capital Market Authority (CMA) board was the formulation of a corporate governance code, which must strictly be complied with by all the Saudi-listed companies. ${ }^{36}$ The CMA implemented many steps for the purpose of decreasing the effect of the local retail investors, such as; firstly, the foreign residents in Saudi Arabia could invest in the economy. Secondly, the market was open for the Gulf Cooperation Council funds and nationals. Thirdly, the CMA limited the allowable participation of Saudi residents in the Initial Public Offerings at 30\%.

The corporate governance in Saudi Arabia is in its infancy phase, and lacks accountability, and displays a weaker legal framework and inadequately protects the shareholders. The board of directors and the audit committees do not play an effective role in the corporate governance. In their analysis, Al-Matari et al stated that the audit committees in the Saudi industries were a vital component of corporate governance. However, they were inefficient as they could not fulfil their roles due to a lack of qualified and independent members. 37 The monitoring mechanisms will be more effective only if they are afforded with a higher authority and independence. 38

Saudi Arabia is a major 'G20' economy, the largest oil producer in the world and a home of some of the biggest global multinational corporations. ${ }^{39}$ The repercussions includes that a corporate governance failure in Saudi Arabia may trigger a crisis to go beyond

35 Al-Matari, Y.A., Al-Swidi, A. K. and Fadzil. F. H. (2012). Corporate Governance and Performance of Saudi Arabia Listed Companies. British Journal of Arts and Social Sciences, 9(1): 21-251, 242. 36 Capital Market Authority. (2006). Corporate governance regulations in the Kingdom of Saudi Arabia. Riyadh, Saudi Arabia.

37 Al-Matari, Y.A., Al-Swidi, A. K. and Fadzil. F. H. (2012). Corporate Governance and Performance of Saudi Arabia Listed Companies. British Journal of Arts and Social Sciences, 9(1): 21-251, 243. 38 lbid.

39 Munisi, G. and Randoy, T. (2013). Corporate Governance and Company Perfor- mance Across Sub-Saharan African Countries. Journal of Economics \& Busi- ness, (70): 92-110, 93. 


\section{International Symposium on Education, Psychology and Social Sciences}

the Middle East and may be extended to developing countries and the global economy. 40

\section{DEVELOPMENT OF THE LAWS ON CORPORATE GOVERNANCE IN SAUDI ARABIA}

The 1965 Companies Law was an important regulation for the Saudi companies. It was based on the British Companies Law and was issued in 1965 by the Royal Decree for the Saudi companies to comply with the rules and guidelines. Although this law was modified to accommodate the developments occurring within the Saudi companies, many, experts were of the view that it was out- dated and could not satisfy the current requirements. ${ }^{4}$

This law was unchanged since 1965, and hence became out-dated. The proposed reform on Company laws was initiated in 2015 and the Ministry of Commerce exerted greater efforts in drafting new laws with improved features. This new law amended and updated the important institutional bodies, like the CMA. Furthermore, it was noted that this law was the sole responsibility of the Minister of Commerce, instead of the CMA, like the following 2016 Law.

The 2016 Companies Law came into force on 2nd May 2016 and presented many reforms. 42 It has 226 Articles and replaced the 1965 Companies Law.43 This 2016 Companies Law was amended in order to be in compliance with the Sharia principles.

40 Al-Bassama, W. M., Ntimb, C. G., Opongc, K. K. \& Downs, Y. (2015). Corporate Boards and Ownership Structure As Antecedents of Corporate Governance Disclosure in Saudi Arabian Publicly Listed Corporations. Business \& Society 1-43. DOI: 10.1177/0007650315610611, 4.

41 Al-Ghamdi, S. and Al-Angari. H. (2005). The Impacts of Implementing Quality Review Program on Audit Firms in the Kingdom of Saudi Arabia: An Empirical Study. Journal of King Abdul-Aziz: Economics and Administration, 19 (2) 48- 77, 40.

42 This Companies Law was executed under the Royal Decree No. (M / 3) dated: 01/28/1437 and the Council of Minister Resolution No. (30) dated 01/27/1437.

43 Issued under the Royal Decree No. (M / 6) dated 03/22/1385 AH, thereby eliminating all the conflicts; Alshowish, A. M. (2016). An Evaluation of the Current Rules and Regulatory Framework of Corporate Governance in Saudi Arabia: A Critical Study in Order to Promote an Attractive Business Environment. Faculty of Arts and Social Sciences, The Law School, Lancaster University. PhD dissertation, available at http://www.lancaster.ac.uk/people- profiles/abdullahalshowish (accessed 4 April 2018). 


\section{International Symposium on Education, Psychology and Social Sciences}

The2016 Companies Lawwasintroducedto reconcileinconsistencies between the 1965 Companies Law and the 2003 Capital Market Law, with regards to the shareholding companies. It consists of many articles which highlight the responsibilities of the CMA and the Ministry of Commerce. This law is believed to be capable of dealing with the issues that decreased the effective working of companies because of bureaucracy.

There are similarities between the corporate governance and company law. The Saudi's New Companies Law provides that the general assembly meetings can be convened using the current communication processes, or the introduction of a novel and cumulative voting system for electing the members forming the board of directors; 44 general assembly of the shareholders, which establish the audit committee for supervising the company activities, wherein the executive board members were ineligible for the audit committee membership. Also, the chairman position cannot be combined with other executive positions. ${ }^{45}$ This new company law consists of many detailed provisions that indicate the division of power in the company and the execution of this power. Though this law is generally flexible, some areas are still unregulated. In such cases, the governance codes are implemented for resolving the issues that carry risks. A few of these risks, which are not resolved by the company law, have been described below, followed by all governance codes used for resolving these risks 46 .

In order to ensure the effective functioning of the board of directors, the provisions in the governance codes and the company law must be considered, since there is a symbiotic correlation between them. The new 2016 Saudi Company Law is capable of addressing several issues related to corporate governance. If the issues arise consist some risks, the principles under the governance codes are used to bridge the gaps where the risks occur. As mentioned before, the collapse of the Saudi Exchange in 2006 triggered the development of the new corporate governance codes to bridge the above-mentioned gaps. Thereafter, the 2006 Saudi corporate governance codes were

44 Article 95 of the Saudi New Companies Law.

45 Article 81 of the Saudi New Companies Law.

46 Ndlovu, B. (2017). The Interplay Between Corporate Governance and Company Law, available at https://www.linkedin.com/pulse/interplay-between-corporate- governance-company-lawbonani-ndlovu/ (accessed 12 March 2018). 


\section{International Symposium on Education, Psychology and Social Sciences}

amended in 2009, reflecting the new developments occurring in this area, in the hope that the Saudi companies stayed on par with the international standards. This law was later amended in 2017, and the existing status of the new Saudi codes on corporate governance is discussed below.

\section{THE CURRENT SAUDI CODES ON THE CORPORATE GOVERNANCE}

The CMA board of Saudi Arabia released a new corporate governance code in April 2017 for the joint stock Saudi companies, listed on the Saudi Exchange. This code replaced the 2009 code and provide the shareholders and the board members with higher clarity, more rights and transparency with regards to their responsibilities and duties. One of the main objectives of the 2017 code is to attract further foreign investments into Saudi Arabia. The 2017 code complements the CMA rules and the new 2016 Company Law, which is supervised by the Saudi Ministry of Commerce and Investment. The CMA implements this code to improve the regulatory oversight of all listed companies thereby improving its standards, similar to the other global exchanges.

The new Saudi corporate governance code is derived from the UK- based "comply or explain" compliance and the disclosure regime. 47 This code is different from that used in theAngloAmerican countries, and requires all the companies to go above and beyond the restricted financial and regulatory features of the corporate governance as it addresses the interests of all the stakeholders, like customers, employees, creditors, suppliers and the local communities. 48 The "Voluntary disclosure" is defined as the voluntary corporate governance compliance and the disclosure regime including the "comply or explain", which enables the managers and directors to comply with and disclose all corporate governance mechanisms used

47 Organization for Economic Cooperation and Development. Principles of Corporate Governance. (1999). Available at http://www.oecd.org/ officialdocuments/publicdisplaydocume ntpdf/?cote=C/MIN(99)6\&docLangua ge=En(accessed February 2018).

48 Capital Market Authority. (2006). Corporate governance regulations in the Kingdom of Saudi Arabia. Riyadh, Saudi Arabia. 


\section{International Symposium on Education, Psychology and Social Sciences}

in the companies and to explain if they could not comply with the corporate governance provisions under the Saudi governance code.

\section{SALIENT FEATURES OF THE SAUDI CODE ON THE CORPORATE GOVERNANCE 2017}

Shareholder Rights

The new Saudi corporate governance code includes many provisions regarding the Shareholder's rights, such as - right against discrimination amongst the shareholders of one class; a fair treatment among the shareholders, unbiased distributions, right to vote in the general assemblies or the audit and board member selection, and equal rights for accessing the corporate information and communication. ${ }^{49}$ Some mechanisms described the distribution of insolvency pay-outs and dividends.

\section{Board of Directors}

Article 16-41 in the new 2017 Saudi Code on the Corporate Governance provides a comprehensive set of rules and principles relating to the governing board of directors like the independent directors, Chairman, and board secretary. Some other rules regarding the board composition, formation, appointment, termination, membership conditions, responsibilities, independence, major functions, meeting-related procedure, distribution of competencies or duties, auditing, and training, etc. are included in the code. The Saudi new code 2017 ensures that the fiduciary duties should be based on the principles of honesty, loyalty and truthfulness.

This new Saudi code 2017 states that a majority of the company's board members must include the non-executive directors, while the total number of independent directors must be more than 2 or less than $33 \%$ of the board members, whichever is higher. 50 It is illegal to simultaneously hold the positions of the board Chairman or other executive position, like the Chief Executive Officer, Managing Director, or General Manager, though the Company's bylaws

\footnotetext{
49 See Articles 4 to 15 of the Saudi Code on Corporate Governance2017.

50 Article 16 (2 and 3) of the Saudi Code of Corporate Governance 2017.
} 


\section{International Symposium on Education, Psychology and Social Sciences}

permit it. ${ }^{51}$ With regards to the board independence, the Saudi code 2017 states that the board must annually determine the degree of the member's independence and warrant that no circumstances or relationships affect the member's independence. 52

\section{Conflicts of Interest}

The Saudi new code 2017 on the corporate governance includes many provisions regarding the assessment, avoidance, and disclosure of any conflicts of interest in the board. One must establish the processes and policies related to the party transactions, conflicting scenarios (within the company or with its competitors), gift acceptance, conflicted people, and compliance with the authorities, renewal or termination of all board members, in accordance with the Companies Law. 53

\section{Committees}

Articles 83-88 of the Saudi new code 2017 describe all provisions associated with the composition, formation, responsibilities, membership, procedures, powers, policies, meetings or all announcements regarding the risk management, remuneration, audits, corporate governance or nomination. With regards to the constitution of the Remuneration Committee Article, Article 60 stated that:

a) The Company board should set up a new committee, known as the "Remuneration Committee." The members of this committee must not be the executive directors, and there must be a minimum of one independent director amongst the members.

b) The General Assembly of the Company, based on the board recommendations, must issue a regulation for this Remuneration Committee, which provides for its duties, rules and processes in selecting the board members, their membership terms and also their remuneration.

Article 70 of the Saudi new code 2017 describes the composition

51 Article 24(b) of the Saudi Code of Corporate Governance 2017.

52 Article 20(b) of the Saudi Code of Corporate Governance 2017.

53 Articles 42 \& 49 of the Saudi Code of Corporate Governance 2017. 


\section{International Symposium on Education, Psychology and Social Sciences}

of this Risk Management Committee, and states that the Company board must form a committee by resolution, known as the 'risk management committee'. The chairman and the board members are called the Non-Executive Directors, and must possess a proper knowledge about risk management and finance".

With regards to the Audit Committee formation, Article 54 of the Saudi new code 2017 states that:

a) The audit committee is formed through the resolution of Company's Ordinary General Assembly. The members of this audit committee must include the shareholders or other members if it includes no Executive Director and at least one of the members is an Independent Director. Further, the audit committee must include 3-5 members only, and one of the members must specialise in the field of finance or accounting.

b) The audit committee chairman must be an Independent Director.

c) The General Assembly of the Company must issue regulation for an auditcommittee, which includes the rules and processes for all duties and activities of the committee, rules for selecting the committee members, terms for their membership and nomination, their remunerations, and mechanisms for appointing temporary members, if the seat in this committee got vacated, based on the board recommendations.

d) Any individual who worked or works in the finance department or executive management of the company, or was an external auditor for the company in the last 2 years, cannot become the audit committee member.

The Saudi new code 2017 further states that in the cases where conflicts arose between the audit committee recommendations and the board members, or if the company board is not ready to implement the committee's recommendations with regards to the appointment or termination of the company's external auditors, or determination of their remuneration, appointment of an internal auditor or their performance, the report presented by the board must include all the committee justifications and recommendations along with reasons for not following these recommendations. 54

54 Article 56 of the Saudi Code of Corporate Governance 2017. 


\section{International Symposium on Education, Psychology and Social Sciences}

Stakeholders

Based on the Saudi new code 2017, the board of the listed companies must produce effective and written policies which can highlight the dealings with the different stakeholders, like employees and some incentives offered to them. ${ }^{55}$ All these policies describe the manner in which the rights of the shareholders must be protected and also presents techniques for the purpose of dealing with the complaints, professional conduct, treatment of the employees, confidentiality of information, social contributions, and handling the non-compliance of the processes and policies. Furthermore, the employee incentive schemes and pay-outs should be documented. 56 Different policies must be presented to govern the ethical and professional corporate standards, social initiatives and social responsibilities.

General Disclosures and Transparency

The companies must disclose and present their accurate and updated information to the various stakeholders of the company, as mentioned in the Capital Market law and the Companies Law, as necessary. ${ }^{57}$ The company board must maintain all the policies with regards to the information disclosure and offer a general board report along with the audit committee's report, and also maintain the information on the company website. 58 The remuneration of the executive committee and the board members should be disclosed as per the standard template, as mentioned in the Regulation. ${ }^{59}$ All the company records (minutes, reports, documents, etc.) should be adequately maintained for a period of at least 10 years. 60

Article 13(d) of the Saudi new code 2017 states that the notice of the General Assembly meeting must include the place, date and the agenda of the meeting, for at least 10 days before the date. Further, the invitation must be published on the websites of the Company and the Exchange, and also in the daily newspaper which is distributed in the area where the Company headquarters are located. Article

\footnotetext{
55 Article 83 of the Saudi Code of Corporate Governance 2017.

56 Article 85 of the Saudi Code of Corporate Governance 2017.

57 Article 89 of the Saudi Code of Corporate Governance 2017.

58 Article 90 of the Saudi Code of Corporate Governance 2017.

59 Article 90(8) of the Saudi Code of Corporate Governance 2017.

60 Article 96 of the Saudi Code of Corporate Governance 2017.
} 


\section{International Symposium on Education, Psychology and Social Sciences}

13(d) states that the Company should also invite the Special and the General Shareholder Assemblies using contemporary tools and technologies.

\section{THE DEVELOPMENT OF CORPORATE GOVERNANCE IN MALAYSIA}

The economic crisis which hit many of the Asian countries in 1997- 1998, encouraged the efforts at improving the corporate governance in Malaysia. ${ }^{61}$ Consequently, the country made many efforts for the purpose of restructuring and improving its corporate governance practices and framework, which as a result led to the introduction of the first code of corporate governance in March 2000.62 After the introduction and development of the MCCG in 2000, the country's administration made many progresses to improve the corporate governance standards. 63 The MCCG in 2000 was a hybrid in nature and similar to the UK code of corporate governance. 64 Using this process, the Malaysian companies need to apply comprehensive principles related to corporate governance set by the code according to the different settings of the individual corporations. 65 It was not compulsory to comply with the code. However, it was mandatory that the companies listed under the Bursa Malaysia (Formerly known as Kuala Lumpur Stock Exchange (KLSE) to include a narrative statement in the annual report the manner in which they have applied the principles and the best practices as prescribed by the Code. They also must identify and offer reasons in the areas of non-compliance, along with the alternative practices that they have adopted.

61 special Report on Malaysia. (2010). Evolution of Corporate Governance in Malaysia. Journal on Corporate Governance in Asia, 7 (3): 1-44, 20; Zulkafl, A., Abdul Samad, M. F., and Ismai, M. D. (n.d). Corporate governance In Malaysia, available at http://www.gomalaysiatour.com/ administrator/admin/ pdf/4dcf82cb5b8dc.pdf (accessed 7 April 2018, 1.

62 special Report on Malaysia. (2010). Evolution of Corporate Governance in Malaysia. Journal on Corporate Governance in Asia, 7 (3): 1-44, 20.

63 Monsod, A. (2010). Malaysian Corporate Governance. Journal on Corporate Governance in Asia, 7 (3): 1-44, 1.

64 Zulkafl, A., Abdul Samad, M. F., and Ismai, M. D. (n.d). Corporate governance In Malaysia, available at http://www.gomalaysiatour.com/administrator/ admin/pdf/4dcf82cb5b8dc.pdf (accessed 7 April 2018, 1.

65 lbid. 


\section{International Symposium on Education, Psychology and Social Sciences}

The other important reforms followed such as that the formulation of a 10-year master plan for the capital markets in 2001, along with the demutualisation of the stock exchange, Bursa Malaysia. The disclosure rules were further amended in 2004. Thereafter, in 2008, a department of corporate governance was established, and additionalterms likethe'corporatesurveillance'and the investigation division of the Bursa Malaysia were introduced for the purpose of implementing and monitoring the corporate governance policies of all the listed companies, which aligned to the corporate governance practices of Malaysia and on par with the international standards. 66

Earlier debate relating to corporate governance in Malaysia was limited to the agencies that were directly involved in law enforcement like the Kuala Lumpur Stock Exchange (KLSE), Ministry of Finance, Securities Commission (SC) and the Registrar of Company. 67 The major sources of the corporate governance reform agenda in Malaysia were derived from the MCCG, presented by the Finance committee on the corporate governance, Capital Market Master Plan (CMMP)68 presented by the Securities Commission (SC) and the Financial Sector Master Plan (FSMP) by the Bank Negara Malaysia. They offer guidelines regarding the best practices and principles related to the corporate governance, and also provided a direction for the purpose of implementing and charting the future prospects of the corporate governance in Malaysia. 69

The legislative and the regulatory framework of the corporate governance in Malaysia were based on the SC Act and the then Securities Industry Act of 1983 (presently under the Capital Market and Services Act 2007). The Malaysian Companies Act 2016 was

$66 \quad$ Ibid.

67 Abidin1, N. Z. and Ahmad, H. N. (2007). Corporate Governance in Malaysia: The Effect of Corporate Reforms and State Business Relation in Malaysia. Asian Academy of Management Journal, 12 (1): 23-34, 34.

68 It is important to note here that the Malaysia's Capital Market Masterplan was drafted to guide the development of Malaysia's Capital Markets during the decade of 2001 to 2010. For the Malaysia's Capital Market Masterplan to project the economy of Malaysia, it requires RM 930 Billion in the new Capital Expenditures. See Ajit, R. \& Yusof, Z. A. (2005). Development of the Capital Market in Malaysia, Tokyo Club Foundation for Global Studies, 7.

69 Zulkafl, A., Abdul Samad, M. F., and Ismai, M. D. (n.d). Corporate governance In Malaysia, available at http://www.gomalaysiatour.com/administrator/admin/ pdf/4dcf82cb5b8dc.pdf (accessed 7 April 2018. 


\section{International Symposium on Education, Psychology and Social Sciences}

introduced which provides provisions for the shareholders to take part and vote in the company meetings and shareholders ballot. The Malaysian Companies Act of 2016 allows shareholders to dismiss the board members any time during their office term.

The revised MCCG 2007 introduced many important changes in the Malaysian corporate governance, which include the definition of the eligibility criteria while appointing directors, board composition and the role played by the nominating committee, etc. The major responsibilities of the corporate governance department of the Bursa Malaysia included: formulation of shortterm and long-term governance policies to achieve a higher standard; uplifting the corporate governance ratings at the international level; planning and implementation of appropriate measures to enhance the standards of the corporate governance amongst the listed companies; monitoring the standard of the corporate governance amongst others. Thereafter, the MCCG was again reviewed in 2012 to keep itself relevant and aligned with the internal standards and practices. The 2017 MCCG version, which succeeded the 2012 version, used a novel approach for supporting the internalisation of the corporate governance culture. 70

\section{THE CURRENT MALAYSIAN CODE ON THE CORPORATE GOVERNANCE 2017}

The new MCCG 2017 was sanctioned by the SC, Malaysia and came into effect on 26th April 2017 replacing the MCCG 2012. The new MCCG 2017 contains many principles for the purpose of improving the standards of the corporate governance of the Malaysian companies. The MCCG 2017 introduced the 'Comprehend, Apply and Report' (CARE) or the 'apply or explain an alternative' process, which is a deviation of the 'comply or explain' approach, used by the MCCG 2012. ${ }^{71}$ This approach offers a higher degree of flexibility while applying the best practices. Further, the MCCG 2017 is applicable to all the listed Malaysian companies, wherein some activities could be practised by only the 'Large Companies', which included the companies on the Bursa Malaysia Top 100 Index or

$70 \quad$ Section 2.5 of the MCCG 2017.

71 Section 2.5 of the MCCG 2017. 


\section{International Symposium on Education, Psychology and Social Sciences}

companies with an RM2 billion market capitalisation. ${ }^{72}$ Furthermore, the MCCG 2017 encourages many non-listed corporations like the Government-linked Corporations, Small and Medium Enterprises, and the licensed intermediaries to implement the MCCG 2017, accordingly they are improving their transparency, accountability, and sustainability. ${ }^{73}$ As per this code, the companies have to offer an explicit explanation in their annual reports with regards to the manner in which all activities were conducted, and also present some alternative activities to achieve the Intended Outcome, provide reasons for these alternatives and present an appropriate timeframe for their implementation. 74 The initial set of companies which are required to report their conformity with the new MCCG 2017 in their annual reports include the companies whose financial year ended on $31^{\text {st }}$ December 2017.

The new MCCG 2017 provides 36 practices which support the 3 principles of broad and effective leadership; an effective auditing, risk management and internal control; and the corporate reporting and a relationship with the stakeholders. During the official release of the MCCG 2017, Tan Sri Ranjit Ajit Singh, Chairman of the Malaysian SC, stated that the new code is a vital component of Malaysia's journey towards the promotion of good corporate governance and for ensuring the resilience and sustainability of the capital market. This new code could act as a compass for the boards who wish to guide their companies in the forward direction and emphasise the relevance of corporate governance. The next section presents the salient features of the MCCG 2017.

\section{HIGHLIGHTS OF THE SILENT FEATURES OF MCCG 2017}

Independence of all Boards

In order to increase the independence of the boards, the new MCCG 2017 requires that a minimum of $50 \%$ of the board members must be independent directors, and in the case of the Large Companies,

\footnotetext{
72 Section 2.6 of the MCCG 2017.

73 Section 2.7 of the MCCG 2017.

74 section 6 of the MCCG 2017.
} 


\section{International Symposium on Education, Psychology and Social Sciences}

the majority of the board members must be independent directors. 75 The MCCG 2017 requires that the independent director must not serve a term of 9 years. 76 In addressing the issues relating to the long tenure of the directors, the new MCCG 2017 provides that if a company wishes to retain their independent directors beyond 9 years, it is required to secure the approval of the shareholders, while the retention of the independent directors for a period beyond 12 years requires the shareholder's approval using the 2-tier voting process. ${ }^{77}$ Additionally, for justifying the retention of the independent directors beyond the cumulative term of 9 years, the board must conduct a very intensive review and determine if the 'independence' of the director was impaired. ${ }^{78}$ The results of the review must be disclosed to all shareholders so that they can make informed decisions.

\section{Transparency in the Directors' Remuneration}

Previously under the MCCG 2012, the boards were required to establish some transparent and formal remuneration processes and policies for the directors, which must be disclosed in their annual reports. The new MCCG 2017 provides that the company must mention these processes and policies on its website. 79 Furthermore, the MCCG provides that a detailed disclosure must be provided about the remuneration that has to be offered to all the directors, with respect to the fees, benefits, bonuses, and other emoluments, and also the amount of remuneration that is paid to the Top 5 people in the senior management. 80 The Malaysian Companies Act 2016 provides that all the fees of the directors and such benefits offered to the directors of the public company (unlisted or listed) must be approved by all shareholders in the general meeting. The disclosure requirements to be made under the MCCG 2017 means that the emphasis on the need to maintain transparency regarding the accountability and remuneration to the shareholders. Also, the Remuneration Committee must consist of only the non-executive directors. Amajority of these non-executive directors are independent

75 Practice 4.1 of Principle A Board Composition II MCCG 2017.

76 Practice 4.2 of Principle A Board Composition II MCCG 2017.

77 Practices 4.2 and 4.3 of Principle A Board Composition II MCCG 2017

78 Guidance 4.2 of the Principle A Board Composition II MCCG 2017.

79 Practice 6.1 of Principle A Remuneration III MCCG 2017.

80 Practice 7.1; 7.2; and 7.3 of Principle A Remuneration III MCCG 2017. 


\section{International Symposium on Education, Psychology and Social Sciences}

directors, who can seek advice from other experts, as needed. ${ }^{81}$ The Guidance 6.2 of the Principle A requires that the directors who are shareholders must avoid voting in the general meetings held to approve their remuneration and fees.

Strengthening the Independence of the Audit Committee

The new MCCG 2017 provides that the Audit Committee Chairman must be the Board Chairman. 82 The Practice 8.2 of the Principle B Effective Audit and Risk Management, Audit Committee MCCG 2017 provides that the Audit Committee should highlight the processes and policies for assessing the objectivity, suitability and the independence of all external auditors. This was recommended to be the "Step Up" practice for a committee, which comprises of only independent directors. 83

\section{Risk Management Committee}

The new MCCG 2017 provides that the board must develop a Risk Management Committee consisting of independent directors for overseeing the company's risk management framework, policies and their implementation. 84 The Practice 9.2 of Principle B Risk Management and Internal Control Framework MCCG 2017 provides that the board must disclose all features regarding the risk management and the internal control framework along with the effectiveness and the sufficiency of the framework.

Participation at the General Meetings

Based on the 2012 code approach, which promoted a dynamic relationship between the company and all shareholders, the new MCCG 2017 further introduced many requirements aimed at improving this relationship, in the following manner;

81 Guidance 6.2 of Principle A Remuneration III MCCG 2017.

82 Practice 8.1 of Principle B Effective Audit and Risk Management, Audit Committee MCCG 2017.

83 Practice 8.4 of Principle B Effective Audit and Risk Management, Audit Committee MCCG 2017.

84 Practices 9.1 and 9.3 of Principle B Risk Management and Internal Control Framework MCCG 2017. 


\section{International Symposium on Education, Psychology and Social Sciences}

a) Notice of the annual general meeting must be given a minimum of 28 days prior to the meeting date. The 2016 Companies Act necessitates a 21-day notice). 85

b) All the directors mustattendthe general meetings for engaging with their shareholders (Practice 12.2 Part C Integrity in Corporate Reporting and Meaningful Relationship with Stakeholders, Conduct of General Meetings MCCG 2017).

c) The listed companies, who have a large number of shareholders, conduct meetings in some remote locations for leveraging the technology for facilitating the electronic voting and for encouraging the remote shareholders to participate in the meetings. 86

\section{Board Diversity}

While pursuing the gender diversity agenda, the new MCCG 2017 provides that every company must take some steps to ensure that the women candidates are recruited for the board and Senior Management Positions. 87 The Guidance 4.5 of the Principle A Board Composition II MCCG 2017 provides that women are to constitute at least 30 percent of the board membership of large companies.

Relationship with the Stakeholders

The new MCCG 2017 provides that the board must maintain transparent, effective and constant communication with all the stakeholders, and all larger companies are required to adopt a more integrated reporting system based on the globally-recognised framework. 88 Furthermore, the new MCCG 2017 introduced many requirements which help in improving the participation and the engagement of the shareholders with the board members during the general meetings. ${ }^{89}$

85 Practice 12.1 Part C Integrity in Corporate Reporting and Meaningful Relationship with Stakeholders, Conduct of General Meetings MCCG 2017.

86 Practice 12.3 Part C Integrity in Corporate Reporting and Meaningful Relationship with Stakeholders, Conduct of General Meetings MCCG 2017.

87 Guidance 4.4 of the Principle A Board Composition II MCCG 2017.

88 Practice 11.1 and 11.2 of Part C Communication with Stakeholders I MCCG 2017.

89 Practices 12. 1 to 12.3 of Part C Conduct of General Meetings II MCCG 2017. 


\section{International Symposium on Education, Psychology and Social Sciences}

A COMPARATIVE STUDY OF THE CODE ON CORPORATE GOVERNANCE IN SAUDI ARABIA AND MALAYSIA

The new Saudi code 2017 and the new MCCG 2017 provide for the establishment of independent board that must consist of a majority of independent directors as board members. Both codes recognised the need for these companies to develop committees for remuneration, auditing, risk management to ensure adequate transparency, accountability and sustainability. Similarly, the Saudi 2017 and the MCCG 2017 codes mandate the board in maintaining the policies related to the information disclosure and state that the board and the audit committee reports must be published on the company website. Both codes state that the company board must disclose the remuneration of all board members and executives, as per the template. The two codes require the companies to maintain appropriate records for a 10-year period.

Though the codes consist some similar provisions, they still differ to a certain extent. The MCCG 2017 code deviated from the conventional process of 'comply or explain' to adopt the 'apply or explain an alternative' approach, known as the 'Comprehend, Apply and Report' (CARE) approach. On the other hand, Saudi Arabia still uses the 'comply or explain' approach. Despite the fact that these codes contain specific provisions to strengthen the relationship between a company and its stakeholders, the new Saudi code 2017 provides some broad provisions that increasing theshareholder rights. The Saudi code 2017 provides explicit and dedicated provisions for these rights.

The new MCCG 2017 provides better processes and rules prescribing the independence of the director by addressing issues relating to the effect of a longer tenure of the directors. The new MCCG 2017 discourages an independent director from having a tenure beyond 9 years. However, if the company wishes to retain a specific director beyond 9 years, the board needs to seek the shareholders' approval. The retention of the independent director for more than 12 years also requires the shareholders' approval using a two-tier voting process.

Irrespective of the consistency of the 2 codes with regards to the strength of the relationships between the shareholders and the 


\section{International Symposium on Education, Psychology and Social Sciences}

company, the new MCCG 2017 code states that the company must give a 28-day notice to the shareholders for any meeting, compared to 10 days mentioned in the Saudi 2017 code. Finally, with regards to the gender diversity agenda, the MCCG 2017 provides a better standard to improve women participation in the company's affairs. The Saudi 2017 code does not address the gender issue by prescribing a specific percentage or quota for women with respect to the board or the Senior Management Positions. Table 1 compared the new Saudi code 2017 and the MCCG 2017.

Table 1: Comparison of the Saudi Code 2017 and the MCCG 2017

\section{Saudi Arabia New Code}

2017

1. Use of the Comply or Explain Approach

2. Offer explicit, dedicated, and broad provisions about the shareholders' rights

3. Do not offer any provisions regarding the process to be implemented if the company wishes to retain a director after 9 years

4. Offers a 10-day notice period before any meeting

5. Offers no women quota or percentage for recruiting women in the board or for any senior management position
MCCG 2017
Use of the Comprehend, Apply and Report (CARE) approach

Offer fewer provisions regarding the shareholders' rights

Offer a procedure to be followed if the company wishes to retain some director for more than 9 years

Offers a 28-day notice period before any meeting

Accepts gender diversity agenda and offers better standard with regards to the participation of women in the company affairs

\section{CONCLUSION}

This paper discusses the corporate governance frameworks under the Saudi Arabia new code 2017 and the MCCG 2017. The two legal 


\section{International Symposium on Education, Psychology and Social Sciences}

frameworks have their similarities and differences. The study finds that the MCCG 2017 should provide more dedicated and explicit provisions with regards to the shareholders' rights as provided for under the Saudi code 2017. The stipulated rights are meant to safeguard the interests of all shareholders and in consequence they are encouraging external investments into the companies. At the same time, Saudi Arabia should also provide certain clauses as available under MCCG 2017 with regards to the independent directors who served for more than 9 and 12 years, respectively, in order to improve the independence of the company's board and ensuring an impartial decision-making. Saudi Arabia Code 2017 should also provide that the company to give a notice of 28 days before any general meeting, compared to a 10-day notice as is presently, to be equal to the MCCG 2017. Similar to that under the MCCG 2017, Saudi Arabia should encourage the companies to increase the participation and recruitment of women in the board and at senior management positions, thereby improving gender diversity, as already mentioned in the MCCG 2017.

\section{References}

1. Abidin, N. Z., \& Ahmad, H. N. (2007). Corporate governance in Malaysia: The effect of corporate reforms and state business relation in Malaysia. Asian Academy of Management Journal, 12 (1), 23-34.

2. Aguilera, R., Williams, C., Conley, J., \& Rupp, D. (2006). Corporate governance and social responsibility:Acomparative analysis of the UK and the US. Corporate Governance: An International Review, 14(3), 147-158.

3. Ajit, R., \& Yusof, Z. A. (2005). Development of the capital market in Malaysia. In Tokyo Club Foundation for Global Studies.

4. Al Mutairi, O. (2003). Apply the procedures governing the companies in Saudi Arabia. Arab Journal of Administrative Sciences, Arabic Ed., 15 (3), 1-50.

5. Al-Bassama, W. M., Ntimb, C. G., Opongc, K. K., \& Downs,

6. Y. (2015). Corporate boards and ownership structure as antecedents of corporate governance disclosure in Saudi Arabian publicly listed corporations. Business \& Society, 1-43. DOl: 10.1177/0007650315610611

7. Al-Ghamdi, S., \&Al-Angari. H. (2005). The impacts of implementing

8. quality review program on audit firms in the kingdom of Saudi 


\section{International Symposium on Education, Psychology and Social Sciences}

9. Arabia: An empirical study. Journal of King Abdul-Aziz: Economics and Administration, 19 (2), 48-77.

10. Al-Haddab, B., \& G. V. Puig. (2013). The protection of minority shareholders in the Gulf cooperation council. Journal of Corporate Law Studies, 13.

11. Al-Kahtani, F. S. (2013). Current practices of Saudi corporate governance: A case for reform (Unpublished doctoral dissertations), School of Law, Brunel University.

12. Al-Matari, Y. A., Al-Swidi, A. K., Fadzil. F. H. (2012). Corporate governance and performance of SaudiArabia listed companies. British Journal of Arts and Social Sciences, 9(1),21-251.

13. Alshowish, A. M. (2016). An evaluation of the current rules and regulatory framework of corporate governance in Saudi Arabia: A critical study in order to promote an attractive business environment. Faculty of Arts and Social Sciences, The Law School, Lancaster University (Unpublished doctoral dissertations). Retrieved from http://www.lancaster.ac.uk/ people-profiles/abdullah-alshowish.

14. Bolkestein, F. (2003). Modernising company law and enhancing corporate governance in the EU: The way forward. Retrieved from europa.eu/rapid/press-release_SPEECH-03-298_ en.doc

15. Capital Market Authority. (2006). Corporate governance regulations in the Kingdom of Saudi Arabia. Riyadh, Saudi Arabia.

16. Capital Markets Guide. (2008). Middle East: Towards innovation and transparency. Retrieved from http://www.gtpak.com/ Publications/Downloads/memg_report_final.pdf (accessed 25 March 2018)

17. Christopher, L. O. (2017). The Malaysian Code on Corporate Governance 2017. Retrieved from https://www. christopherleeong.com/media/2803/clo-2017-05-the- malaysian-codeonf.pdf (accessed 9 April 2018).

18. Demirag, I., \& Solomon, J. (2003). Guest editorial: Developments in international corporate governance and the impact of recent events. Corporate Governance: An International Review, 11 (1), 1-7.

19. El-Khudery. M. (2005). Corporate governance. Arabic edition.

20. Egypt: Arab Nile Group.

21. Falgi, K. I. (2009). Corporate governance in Saudi Arabia: A stakeholder perspective. (Unpublished doctoral dissertations). University of Dundee.

22. Goo S. H., \& Carver, A. (2003). Corporate governance; The Hong Kong debate. Asia: Sweet \& Maxwell. 


\section{International Symposium on Education, Psychology and Social Sciences}

23. Grais, W., \& Pellegrini, M. (2006). Corporate governance in Institutions Offering Islamic Financial Services: Issues and options. World Bank Policy Research Working Paper, No. 4052.

24. Ho, S., \& Wong, K. (2001). A study of the relationship between corporate governance structures and the extent of voluntary disclosure. Journal of International Accounting, Auditing and Taxation, 10 (2), 139-156.

25. Kocmanová1, A., Hrebicek, J., Docekalova, M. (2011). Corporate governance and sustainability. Economics and Management, 16.

26. Lewis, M. (2005). Islamic Corporate Governance. Review of Islamic Economics, 5 (9): 5-29.

27. Lupu, L. (2015). The Indirect Relation Between Corporate Governance and Financial Stability. Procedia Economics and Finance, (22): 538-543.

28. Meteb, M. A. (2012). The importance of corporate governance in Saudi Arabian economy. Journal of WEI Business and Economics, 4 (1), 1-25.

29. Mobius, M., Chan, D. (2000). Corporate governance in Hong Kong

30. - Gaps that need to be filled. In Chee-Keong Low (Ed),

31. Financial Markets in Hong Kong. Singapore: Springer.

32. Monks, R., Minow, N. (2004). Corporate governance. Oxford: Blackwell Publishing.

33. Monsod, A. (2010). Malaysian corporate governance. Journal on Corporate Governance in Asia, 7(3), 1-44.

34. Munisi, G., Randoy, T. (2013). Corporate governance and company performance across subSaharan African countries. Journal of Economics \& Business, (70), 92-110.

35. Ndlovu, B. (2017). The interplay between corporate governance and company law. Retrieved from https://www.linkedin.com/ pulse/interplay-between-corporate-governancecompany- law-bonani-ndlovu/ (accessed 12 March 2018).

36. Organization for Economic Cooperation and Development. (1999). Principles of corporate governance. Retrieved from http:// www.oecd.org/officialdocuments/ publicdisplaydocumentpdf/

37. ? cote $=C / M I N(99) 6 \&$ docLanguage $=E n$

38. Ross, S. (2015). What are some examples of different corporate governance systems across the world? Retrieved from https:// goo.gl/8HTqEr 
International Symposium on Education, Psychology and Social Sciences

39. Saudi Code on Corporate Governance. (2017). Saudi New Companies Law. (2015).

40. Solomon, J., \& Solomon, A. (2004). Corporate governance and accountability. England: John Wiley \& Sons, Chichester.

41. Special Report on Malaysia. (2010). Evolution of corporate governance in Malaysia. Journal on Corporate Governance in Asia, 7(3), 1-44.

42. Zulkafl, A., Abdul Samad, M. F., \& Ismai, M. D. (n.d.). Corporate governance in Malaysia. Retrieved from http://www.gomalaysiatour.com/administrator/admin/ pdf/4dcf82cb5b8dc.pdf 
INTERNATIONAL SYMPOSIUM ON EDUCATION, PSYCHOLOGY AND SOCIAL SCIENCES

SEPTEMBER, 282019

TOKYO - JAPAN

\title{
case of south african female entrepreneurs
}

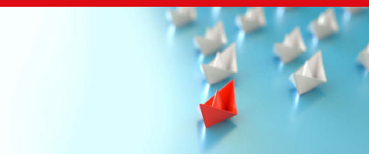

N Meyer \& Dr E Keyser

North-West University - Vaal

Triangle Campus: Vanderbijlpark, ZA

\begin{abstract}
Family responsibility has been identified as a potential unique female entrepreneur challenge. Although some females may willingly enter into entrepreneurial activity when having children as it may provide more work life flexibility, some may be challenged by time restrictions especially when children are still young. However, empirical data show that females who decide to become self-employed may in many cases do so to enjoy higher flexibility but may be restricted regarding growth and other factors such as finances, motivation and support. In light of this, the purpose of this study is to identify differences between two groups of South African female entrepreneurs: those with and those without children. Differences were compared between groups considering several factors such as, motivation, financial constraints, intention to grow the business and sociocultural barriers to name a few. The study followed a descriptive research design using self-administered questionnaires. The questionnaires were distributed to a purposive and convenience sample of female entrepreneurs from all nine South African provinces resulting in a final sample of 510 . Data were analysed using reliability and validity analysis and Multiple Analysis of Variance (MANOVA) and Analysis of Variances (ANOVA). Results indicated that the only entrepreneurial variable or factors that were influenced by having children or not were financial constraints, government support and socio-cultural barriers. Factors such as intention to remain in business, intention to grow the business and motivation returned non-statistically significant results for the said groups. The results from this study link to previous findings indicating that differences were observed between female entrepreneurs with children and those without. Further studies indicate that fewer differences were observed between male entrepreneurs with children and those without children, therefore implying that the presence of children among female entrepreneurs could be considered a unique challenge.
\end{abstract}

Keywords: South Africa, female entrepreneurs, challenges, children JEL Classification: L26 


\section{INTRODUCTION}

During the mid-eighteenth century, the Western industrial era brought about major global changes; however, from the onset females were excluded from mainstream economic contributions and activities. Females and males performed clearly defined and contrasting roles within society. Men were mainly involved in economic activities and public life while women were expected to be mostly homebound, taking care of cleaning, cooking and children. Nonetheless, most developing and developed countries slowly started accepting females as part of the economic sector from the latenineteenth century onwards (Sailus, 2015:1). Recent research on the roles of females in both developed and developing countries suggest that many of them in developing nations continue to play constrained economic roles in agriculture and are restricted to participate as economic equals in these nations (Jayachandran, 2014:4; United Nations, 2008:2). Several aspects may affect female entrepreneurs in a different way compared to males or may have an impact on their business' management style and performance. Such factors include race, age, marital status and children, education, previous work experience and the presence of an entrepreneurial role- model. Some studies have pointed out that having children may contribute to female entrepreneurs' challenges regarding business start-up, continuation and growth (DTI, 2005; Noseleit, 2014). Based on the aforementioned, the research objective of this study is to identify differences in various entrepreneurial variables or factors between two groups of South African female entrepreneurs: those with and those without children. Understanding the magnitude of differences, if any, can contribute to policy development within female entrepreneurship development.

\section{LITERATURE REVIEW}

Entrepreneurship has been pointed out by many academics and policymakers alike as the cornerstone of economic growth and financial independence (Athayde, 2012:709710; Sivvam, 2012:13; Ambrish, 2014:225; Kot, Meyer \& Broniszewska, 2016:207). Despite this, the potential of entrepreneurship has not been fully realised in many developing countries. South Africa is falling behind in terms of entrepreneurship intention and action when compared to sub-Saharan African averages and also other efficiencydriven economies; consequently, advances in this regard are necessary (Herrington, Kew \& Kew, 2015:5). Female entrepreneurs are, in particular, fewer in number than their male counterparts (Asian Development Bank, 2007; ILO, 2014:1; GEM Consortium, 2017), and reasons for this need to be identified. As mentioned, the aim of this study is to identify differences in various entrepreneurial factors between South African female entrepreneurs with and without children. The entrepreneurial factors referred to include internal and external motivation, intention to remain in and grow the business, financial constraints, government support, socio-cultural barriers and attitude towards the 


\section{International Symposium on Education, Psychology and Social Sciences}

business. These factors are subsequently discussed in the following section.

\subsection{Entrepreneurial factors}

Motivation is the first entrepreneurial factor or variable that may potentially be influenced as a result of a female entrepreneur having children or not. Motivation, for the purpose of this study, is divided into internal and external motivation. Internal motivation includes aspects such as increased freedom, work-life balance and making a difference in society, compared to external motivations such as wealth creation and autonomy. Differences between male and female motivation for starting or remaining in business may be present. However, some studies identified similarities as well. Veena and Nagaraja (2013:140), for example, found that one of the primary reasons for self-employment for both genders is to gain more control over their working conditions. In addition, personal autonomy and self-determination were high motivational factors for both genders. However, females reported much higher motivation in an attempt to escape a confined labour market with low paying wages, strong supervisory and hierarchical structures and to discard social stereotypes (Veena \& Nagaraja, 2013:140). Along with other studies, Veena and Nagaraja (2013:140) also found that financial independence was a high motivational factor for both males and females. Nevertheless, females also listed having independence and being able to control their labour inputs as strong motivation. Similar to other findings, Veena and Nagaraja (2013:140) found that flexibility is a major motivational factor for many females deciding to start entrepreneurial ventures. This is not the case for male entrepreneurs. According to Veena and Nagaraja (2013:141) many female entrepreneurs may be more driven by internal motivations, such as increased freedom, work-life balance and making a difference in society, compared to external motivations such as wealth creation and autonomy (Veena \& Nagaraja, 2013:141; Kim \& Sherraden, 2014:50).

Further entrepreneurial factors that may be influenced by the presence of children among female entrepreneurs include their intention to remain in business, grow the business and their attitude towards the business. These three factors are very much linked to one another. Knight and Leimer (2010:111) mention that several factors may directly or indirectly contribute to an individual's intention to remain or leave employment. These include, but are not limited to gender, education, personal traits and interests, motivation, support, promotional opportunity and so forth. Likewise, many of these factors may also have an impact on the entrepreneur's intention to remain in business. Morrison (1997:45), in a study conducted on franchise owners, found that job satisfaction positively influences the decision to remain in business. Considering the factors mentioned by Knight and Leimer (2010:111), factors linking to support, such as government support, access to finance and socio-cultural support may have a direct or indirect impact on a female entrepreneur's intention to remain in business. 
When some of these factors negatively affect the entrepreneur, such as lack of finance, stereotyping, lack of government support and even lack of motivation, the appetite of the entrepreneur (job satisfaction) towards the business may be reduced, which could decrease the intention to remain in business. In addition, Knight and Leimer (2010:111) state that in cases where negative factors influence the employee (entrepreneur), females are more inclined to quit or exit the specific job situation or decide to close the business.

Additionally, Kim and Hunter (1993) found that attitude is a strong predictor of behaviour, especially goal-orientated behaviour $(r=0.79)$. However, attitude may also change quite suddenly due to interactions with the direct environment and could be less stable over time (Wiklund, Davidsson \& Delmar, 2003:149). Delmar and Wiklund (2008:437) further opine that business growth is strongly linked to motivation, especially external motivational aspects; as a result, a further link could be made between motivation, attitude and growth. Motivation affects the choice of behaviour so that when a positive attitude towards the business and business growth are experienced by the entrepreneur, they may be more inclined to external motivational factors for the choice of remaining in business. This assumption is based on Ajzen's (1991) Theory of Planned Behaviour. When considering attitude as a factor of firm growth, it should be noted that growth aspirations may not be instantaneous and may only develop over time. Walker and Brown (2004:579) mention that as businesses mature, the owners may alter their attitudes towards business growth in a positive manner. In addition, Delmar and Wiklund (2008:438) state that this process of motivation towards achieving business growth may take up to 5 years for a small business entrepreneur to actively seek and for a positive attitude towards growth to be developed. Although the aforementioned referred to attitude towards growth, this is closely linked to the entrepreneur's attitude towards the business in general. If the entrepreneur has a strong feeling of commitment, satisfaction, passion and attachment to the business, they may even develop a more positive attitude towards growth, or it may even evolve over time.

The aforementioned factors were more positive-oriented in nature, likewise, several negative factors may also be influenced in a certain manner considering the presence of children among female entrepreneurs. These include financial constraints, lack of government support and socio-cultural barriers. Access to finance and credit for small, medium entrepresis (SMEs) is in many cases a challenge, and for female entrepreneurs, this issue is sometimes even greater (Buttner \& Rosen, 1988:250; Gicheva \& Link, 2015:729). Verheul and Thurik (2001:330) state that female entrepreneurs encounter several challenges concerning the financial aspects of their businesses. These include aspects pertaining to start-up capital and operational capital. These difficulties comprise having smaller equity capital at their disposal, sector related capital restrictions due to many female entrepreneurs operating service industry-related businesses and lending institutions being more reluctant to lend money to entrepreneurs in these sectors. 


\section{International Symposium on Education, Psychology and Social Sciences}

Furthermore, females are, in many instances, likely to be more risk- averse than males, which may lead to their declining higher risk opportunities and lessening subsequent access to finance. In addition, female-owned businesses tend to be smaller in size and less efficient, which may result in more failed loan applications (Makina, Fanta, Mutsonziwa, Khumalo, \& Maposa, 2015:3). When considering government support, South Africa has a lengthy history regarding gender policy restrictions. Black and coloured females were deprived of taking part in any business activity pre-1994 (SAHO, 2011:1; BobbyEvans, 2015). These political policies and lack of government support prevented many females from starting businesses and thinking entrepreneurially. However, initiatives were implemented post-1994 to redress the gender discrimination caused during the Apartheid era (SAHO, 1994:1). Despite these initiatives, there is still much necessary work to be done to level the playing field when it comes to gender representation in the economic business world and entrepreneurship development, and policy formation could assist in this (Herrington, Kew \& Kew, 2010:41).

Finally, many socio-cultural aspects also affect female entrepreneurs more than their male counterparts: some of these include, lack of respect from the community, stereotypical treatment, doubt about their ability to conduct business, discrimination in the labour market and other workplaces, and balancing work and home duties especially when raising children. As entrepreneurship has in the past, and even to a certain extent today, been defined as a masculine and male dominated career option and females have been classified as homemakers and being responsible for raising children, a clearly stereotypical situation has emerged (Onyishi \& Agbo, 2010:3049). Maziku, Majenga and Mashenene (2014:51) mention that many females, especially in developing rural areas, are negatively affected by these socio-cultural and stereotypical aspects and that this may have an effect on the business size, growth potential and eventually, the business success rate.

\subsection{Female entrepreneurs and children}

The Department of Trade and Industry (DTI) (2005:8) identified family responsibility as a potential unique female entrepreneurial challenge. Although some females may willingly enter into entrepreneurial activity when having children as this may provide more worklife flexibility, some may be challenged by time restrictions, especially when children are still young (Noseleit, 2014:550). However, empirical data show that females who decide to become self-employed may in many cases do so to enjoy higher work-life flexibility or to reduce potential work-family conflict (Wilde, Batchelder \& Ellwood, 2010).

DeMartino and Barbato (2003:816) found that fewer differences were observed between males with children and males without children, compared to females with and without children, therefore implying that the responsibility of children among men does not 
have a large effect on their business motivation and activities. Noseleit (2014:550) opines that clear differences in entrepreneurial motivation among gender, married and unmarried gender groups and groups with and without children exist. A study conducted in the USA that included 2840 MBA alumni returned the following results (Table 1) pertaining to marital status, having children or not and the reason for selfemployment. Six motivations were listed that included having career flexibility, being able to create family-friendly policies to assist employees with children, being able to tend to family obligations, forming a co-career with one's spouse, advancing one's career and creating wealth.

\section{Table 1: Reason for self-employment by gender}

\begin{tabular}{|c|c|c|c|c|c|c|}
\hline \multirow[t]{2}{*}{ Motivation } & \multirow[t]{2}{*}{ Female } & \multirow[t]{2}{*}{ Male } & \multicolumn{2}{|c|}{ Married with children } & \multicolumn{2}{|c|}{ Married withoutchildren } \\
\hline & & & Female & Male & Female & Male \\
\hline Career flexibility & 85.4 & 50.8 & 96.4 & 55.3 & 68.4 & 48.1 \\
\hline Family-friendly & 64.6 & 28.7 & 92.9 & 35.0 & 21.1 & 15.4 \\
\hline Family obligations & 54.1 & 22.8 & 78.6 & 29.3 & 15.8 & 11.8 \\
\hline Co-career with spouse & 58.3 & 21.8 & 71.4 & 22.8 & 36.8 & 21.2 \\
\hline Advancement & 23.4 & 42.7 & 17.9 & 43.6 & 27.8 & 47.1 \\
\hline Wealth creation & 29.1 & 75.9 & 21.4 & 76.5 & 36.8 & 76.9 \\
\hline
\end{tabular}

*This sample included only those who were married and self-employed Source: DeMartino and Barbato (2003:824)

Although respondents from the sample had similar backgrounds (Alumni from MBA programmes), demographics, as well as timing and age of business, clear differences in motivation between gender and number of dependents, were noted. From Table 1 it is evident that among married females in total, those with and without children choose to be self-employed to ensure a flexible career in order to achieve a work-life balance. Males in all three comparisons indicated that wealth creation was their main motivation for self-employment. These findings correspond to previous findings by Goffee and Scase (1983), Kaplin (1988) and Buttner (1993), however, they contradict findings by Fischer, Reuben and Dyke (1993). Again, these findings may differ in developing countries where some females may be restricted from starting businesses due to other sociocultural barriers. In light of the aforementioned discussion, the following hypothesis was developed:

H1: There is no significant difference in internal and external motivation, intention to remain in business, intention to grow the business, government support, financial restraints, socio-cultural barriers and attitude towards the business between South African female entrepreneurs who have children and those who do not have children. 


\section{International Symposium on Education, Psychology and Social Sciences}

\section{METHODOLOGY}

\subsection{Research purpose and design}

Following the main purpose of this study, the underlying philosophical underpinning forms part of the positivist paradigm as it predominantly made use of empirical data obtained objectively and interpreted in a statistical manner. This study made use of a descriptive single-sample cross-sectional design approach.

\subsection{Study area and sample}

The target population for this sample included South African female business owners from all nine provinces. Additional criteria included that they owned a majority share in the business and were actively involved in the management aspects of the business. A combination of two non-probability sampling techniques were used in the selection of the sample elements as identified from the target population. First, a purposive sampling technique was utilised as it focuses on characteristics of a population based on the objective of the study, in this case female entrepreneurs owning a business for longer than a year (Crossman, 2017). Second, a convenience sampling technique was employed based on specific participant selection criteria. The decision to utilise this technique was made on the basis that no, or limited, prior knowledge of the precise locations and the names of the individuals from which the sample could be drawn, was available. As the exact population size of female business owners in South Africa is unknown, it was difficult to statistically determine the sample size to present a reflective proportion of the whole population. Avikaran (1994:29) advises that a sample size of between 200 and 500 should be used when undertaking multivariate statistical analysis. A final sample size of 510 female entrepreneurs was obtained and was deemed adequate.

\subsection{Research instrument and procedure}

Data were collected through the use of a self-administered questionnaire. The questionnaire followed a rigorous process of pre-testing and a pilot study before the final study was conducted. The pilot study consisted of a total of 34 female entrepreneurs. As the main study was to be conducted in all nine provinces of South Africa, the pilot study was conducted in one of South Africa's neighbouring countries, Namibia. This was done in an attempt to avoid the possibility that the pilot study respondents may accidentally be included in the main study. The results from the pilot study indicated that the calculated measures of internal- consistency reliability, together with those of convergent and discriminant validity, were deemed acceptable and no changes were made to the questionnaire based on the pilot study results. The final questionnaire was administered through electronic correspondence and trained fieldworkers. Statements 
International Symposium on Education, Psychology and Social Sciences

and questions included in the measuring instrument pertained general demographic information and several constructs directed at obtaining information regarding various entrepreneurial factors. The scaled responses allowed for a selection of between 1 (strongly disagree) to 6 (strongly agree) on a Likert scale and therefore higher means represented a more positive attitude from the respondents based on the specific construct topic.

\subsection{Data analysis}

This analysis employed both descriptive and inferential statistics. In order to address the research hypothesis, statistical analyses were employed and reported on using SPSS 24 for Windows program (SPSS, 2018). Descriptive statistics (means, standard deviations, skewness and kurtosis) of the identified factors (government support, financial constraints, socio-cultural barriers, internal and external motivation, intention to grow, intention to stay in business, attitude towards business) were also computed to describe the data (Table 2). Cronbach alpha coefficients were used to determine the internal consistency of the research instruments. Furthermore, MANOVA and ANOVA analyses were done to determine the significant relationship between dependent variables (the government support, financial constraints, socio-cultural barriers, internal and external motivation, intention to grow, intention to stay in business, attitude towards business) and individual characteristic (fixed factors - female entrepreneurs with and without children) that included women with children and those without children. Firstly, demographic characteristics were analysed for statistical significance using Wilk's Lambda statistics and values on the dependent variables.

\section{RESULTS AND DISCUSSION}

In Table 2 the results of the descriptive statistics and alpha coefficient of the total sample are reported on.

Table 2: Descriptive statistics

\begin{tabular}{|c|c|c|c|c|c|}
\hline Factor/variable & Mean & SD & Kurtosis & $\alpha$ & $\begin{array}{l}\text { Inter-item } \\
\text { correlation }\end{array}$ \\
\hline Government support & 4.452 & -1.080 & 0.908 & & 0.391 \\
\hline Financial constraints & 4.567 & -1.589 & 2.933 & & 0.339 \\
\hline Socio-cultural barriers & 4.148 & -0.603 & -0.448 & & 0.416 \\
\hline Internal motivation & 5.067 & -0.660 & 2.422 & & 0.179 \\
\hline External motivation & 4.867 & -1.054 & 1.865 & & 0.260 \\
\hline Intention to grow & 5.170 & -1.764 & 3.772 & & 0.524 \\
\hline Intention to stay & 5.071 & -1.809 & 5.189 & & 0.372 \\
\hline Attitude towards business & 4.959 & -0.970 & 2.635 & & 0.248 \\
\hline
\end{tabular}




\section{International Symposium on Education, Psychology and Social Sciences}

Table 2 shows acceptable Cronbach alpha coefficients varying from 0.73 to 0.86 (Nunnally \& Bernstein, 1994). Concerning construct validity, the average inter- item correlation values fall within Clark and Watson's (1995:316) recommended levels of 0.15 to 0.50, with the intention to growing a business being marginally higher. As such, it was reasonable to assume convergent and discriminant validity.

Multiple Analysis of Variance (MANOVA) and Analysis of Variances (ANOVA) were used to test Hypothesis (H1): there is no significant difference in internal and external motivation, intention to remain in business, intention to grow the business, government support, financial constraints, socio-cultural barriers and attitude towards the business between South African female entrepreneurs who have children and those who do not have children.

\begin{tabular}{|c|c|c|c|c|c|}
\hline Ttem & Value & $F$ & Df & $\bar{p}$ & $\begin{array}{l}\text { Partial Eta } \\
\text { Squared }\left(\eta^{2}\right)\end{array}$ \\
\hline $\begin{array}{l}\text { Female entrepreneurs } \\
\text { with or } \\
\text { without children }\end{array}$ & 0.93 & 3.19 & 11.00 & $0.00^{*}$ & 0.07 \\
\hline
\end{tabular}

Table 3 clearly indicates that from a South African perspective a significant difference in internal and external motivation, intention to remain in business, intention to grow the business, government support, financial restraints, socio- cultural barriers and attitude towards the business between South African female entrepreneurs who have children and those who do not have children was experienced. Veena and Nagaraja (2013:139) opine that male and female entrepreneur's impact of marital status and having children differs significantly. Males tend to have less conflicting demands when it comes to family responsibility. In addition, the DTI (2005:8) also identified family responsibility as a potential unique female entrepreneur challenge.

The next phase involved identifying where the differences between groups existed because significant effects were identified in the MANOVA analysis (Table 3). ANOVA was used to determine this (George \& Mallery, 2003). Table 4 presents the results from the ANOVA test. 
International Symposium on Education, Psychology and Social Sciences

Table 4: ANOVA results for differences between variables and children status groups

\begin{tabular}{lllll}
\hline Factor/variable & Children & No children & $\mathrm{p}$ & $\mathrm{n}^{2}$ \\
\hline Government support & 4.62 & 4.32 & $0.00^{*}$ & 0.02 \\
\hline Financial constraints & 4.68 & 4.47 & $0.00^{*}$ & 0.02 \\
\hline Socio-cultural barriers & 4.33 & 3.99 & $0.00^{*}$ & 0.03 \\
\hline Internal motivation & 5.05 & 5.08 & 0.58 & 0.00 \\
\hline External motivation & 4.89 & 4.85 & 0.52 & 0.00 \\
\hline Intention to grow & 5.17 & 5.17 & 0.97 & 0.00 \\
\hline Intention to stay & 5.07 & 5.07 & 0.95 & 0.00 \\
\hline Attitude towards business & 4.92 & 4.99 & 0.15 & 0.00 \\
\hline
\end{tabular}

$* \mathrm{p}<0.05=$ significant

$\eta 2>0.25=$ large effect

From a South African perspective, the set hypothesis $(H 1)$ is rejected as significant differences were found between entrepreneurial females with and without children and government support, financial constraints and socio-cultural barriers. Female entrepreneurs with children experience more financial constraints and social barriers than female entrepreneurs without children and also experience the level of government support provided to them differently. Shelton (2006:289) reasons that work-family conflict, such as raising children, is correlated positively to business demands and family role demands. Business demands involve for example hours worked and entrepreneurial aspirations. Family role demands depend on, for example, the ages and number of children and the magnitude of family support. Female entrepreneurs may choose to limit the scope of their businesses in order to reduce potential work-family conflict. The findings also suggest that female entrepreneurs, regardless of their child status are motivated to stay in and grow the business. Their attitude towards the business also remains positive in both situations.

\section{CONCLUSION AND RECOMMENDATIONS}

The significance of this study can be divided into two parts, first, a theoretical and practical influence for female entrepreneurs with or without children. Theoretically, the background of female entrepreneurs' theory and content from an international and South African perspective were discussed. The second part of the study, empirically indicated that the influence of government support, financial constraints and socialcultural barriers play a role for female entrepreneurs with children. In addition, findings indicate that female entrepreneurs are resilient and that even with the added challenge of child-caring responsibilities, they still intend to stay in and grow their businesses and that they have a positive attitude towards their businesses. The presence of children also does not have a significant statistical effect in their overall business motivation. These findings motivate further studies focusing on the relationship between the experience of female entrepreneurs and social context in which they are functioning in and to identify 


\section{International Symposium on Education, Psychology and Social Sciences}

the reasons why female entrepreneurs experience a difference regarding government support, financial constraints and social-cultural barriers. Recommendations emanating from the findings of this study may include the promotion of female entrepreneurial networks and associations, greater media attention on the importance of female entrepreneurship, better implementation of policies and awareness thereof, greater motivation and assistance for business growth, exposing females to the business environment from a young age, greater representation of females in the business world, enhanced finance opportunities and developing a greater understanding of the female entrepreneurship phenomenon.

There are limitations and methodology aspects that affected the results presented in this study. The self-reported procedure utilised can be improved by more controlled application of the questionnaire and could result in minimising the bias of the findings. Time impact on the perception of female entrepreneurs with or without children may differ over time and the impact may only be noticeable at a later stage.

\section{References}

1. Ajzen, I. (1991). The theory of planned behaviour. Organizational Behavior and Human Decision Processes, 50(2),179-211.

2. Ambrish, D.R. (2014). Entrepreneurship development: An approach to economic empowerment of female. International Journal of Multidisciplinary Approach and Studies, 1(6), 224-232.

3. Asian Development Bank. (2007). Technical Assistance Report. Promoting rural women's entrepreneurship in transition economies. Asian Development Bank.

4. Athayde, R. (2012). The impact of enterprise education on attitudes to enterprise in young people: An evaluation study. Education and Training, 54(8/9), 709-725.

5. Avikaran, N.K. (1994). Developing an instrument to measure customer service quality in branch banking. International Journal of Bank Marketing, 12(6), 10-18.

6. Bobby-Evans, A. (2015). Apartheid Legislation in South Africa. http://africanhistory. about.com/library/bl/blsalaws.htm. Accessed: 2015/09/03.

7. Buttner, E.H. \& Rosen, B. (1988). Bank loan officers' percep

8. tions of the characteristics of men, women, and successful entrepreneurs. Journal of Business Venturing, 3(3), 249-258.

9. Buttner, E.H. (1993). Female entrepreneurs: How far have they come? Women in business. Business Horizons, 36(2), 59-68.

10. Clark, L.A. \& Watson, D. (1995). Constructing validity: Basic issues in objective scale development. Psychological Assessment, 7(3), 309-319. 


\section{International Symposium on Education, Psychology and Social Sciences}

11. Crossman, A. (2017). Understanding purposive sampling. An overview of the methods and its applications. www.thoughtco.com. Accessed: 2017/09/23.

12. Delmar, F. \& Wiklund, J. (2008). The effect of small business managers' growth motivation on firm growth: A longitudinal study. Entrepreneurship Theory and Practice, 32(3), 437-457.

13. DeMartino, R. \& Barbato, R. (2003). Difference between women and men.Journal of Business Venturing, 18(2003), 815-832.

14. DTI see Republic of South Africa. Department of Trade and Industry Fischer, E., Reuben, R.A. \& Dyke, L.S. (1993). A theoretical overview and extension of research on sex, gender, and entrepreneurship. Journal of Business Venturing, 8(2), 151-168.

15. GEM Consortium. (2017). Global Entrepreneurship Monitor: Key indicators - Adult population survey measures. http://www.gemconsortium.org/data/key- indicators. Accessed: 2017/05/24.

16. George, D., \& Mallery, P. (2003). SPSS for Windows step by step: A simple guide and reference 11.0 update $\left(4^{\text {th }}\right.$ ed.). Boston, MA: Allyn \& Bacon.

17. Gicheva, D. \& Link, A.N. (2015). The gender gap in federal and private support for entrepreneurship. Small Business Economics, 45(4), 729-733.

18. Goffee, R. \& Scase, R. (1983). Business ownership and women's subordination: A preliminary study of female proprietors. The Sociological Review, 31(4), 625- 648.

19. Herrington, M., Kew, J. \& Kew, P. (2010). Global Entrepreneurship Monitor. University of Cape Town. Cape Town: South Africa.

20. Herrington, M., Kew, J. \& Kew, P. (2015). 2014 GEM South Africa report: South Africa: The crossroads - a goldmine or a time bomb? University of Cape Town Centre for Innovation and Entrepreneurship. Cape Town: South Africa.

21. International Labour Organization (ILO). (2014). Female's entrepreneurship development: Encouraging female entrepreneurs for jobs and development. http:// www.ilo.org/wcmsp5/groups/public/---ed_emp/---emp_ent/--- ifp_seed/documents/ publication/wcms_175471.pdf. Accessed: 2015/07/29.

22. Jayachandran, S. (2014). The roots of gender inequality in developing countries. http://faculty.wcas.northwestern.edu/ sjv340/roots_of_gender_inequality.pdf.

23. Accessed: 2015/09/02.

24. Kaplin, E. (1988). Women entrepreneurs: Constructing a framework to examine venture success and business failure. Frontiers of Entrepreneurship Research, (1988), 625-637. 


\section{International Symposium on Education, Psychology and Social Sciences}

25. Kim, M.S. \& Hunter, J.E. (1993). Relationships among attitudes, behavioral intentions, and behavior: A meta-analysis of past research, part 2. Communication research, 20(3), 331-364.

26. Kim, S.M., \& Sherraden, M. (2014). The impact of gender and social networks on microenterprise business performance. Journal of Sociology \& Social Welfare, 41, 49-69.

27. Knight, W.E. \& Leimer, C.L. (2010). Will IR staff stick? An exploration of institutional researchers' intention to remain in or leave their jobs. Research in Higher Education, 51(2), 109-131.

28. Kot, S., Meyer, N., \& Broniszewska, A. (2016). A cross-country comparison of the characteristics of Polish and South African women entrepreneurs. Economics and Sociology, 9(4), 207-221. DOI: 10.14254/2071-789X.2016/9-4/13.

29. Makina, D., Fanta, A.B., Mutsonziwa, K., Khumalo, J. \& Maposa, O. (2015). Financial access and SME size in South Africa. Occasional Paper (001-2015). University of South Africa.

30. Maziku, P., Majenga, A. \& Mashenene, G.R (2014). The effects of socio-cultural factors on the performance of women small and medium enterprises in Tanzania. Journal of Economics and Sustainable Development, 5(21), 51-63.

31. Morrison, K.A. (1997). How franchise job satisfaction and personality affects performance, organizational commitment, franchisor relations, and intention to remain. Journal of Small Business Management, 35(3), 39-67.

32. Noseleit, F. (2014). Female self-employment and children. Small Business Economies, 43, 549-569. DOI 10.1007/s11187-014-9570-8.

33. Nunnally, J.C., \& Bernstein, I.H. (1994). Psychometric Theory. New York: McGraw-Hill. Onyishi, I.E. \& Agbo, A.A. (2010). Psychological empowerment and development of entrepreneurship among women: Implications for sustainable economic development in Nigeria. Gender and Behaviour, 8(2), 3048-3068.

34. Republic of South Africa. Department of Trade and Industry (DTI). (2005). South African female entrepreneurs. A burgeoning force in our economy: A special report 2005. Pretoria: Government Printer. SAHO see South Africa History Online

35. Sailus, C. (2015). Feminism in the $19^{\text {th }}$ century: Female's rights, roles, and limits. http:// study.com/academy/lesson/feminism-in-the-19th-century-females-rights- roles-andlimits.html. Accessed: 2015/09/02.

36. Shelton, L.M. (2006). Female entrepreneurs, work-family conflict, and venture performance: New insights into the work-family interface. Journal of Small Business Management, 44(2), 285-297. 


\section{International Symposium on Education, Psychology and Social Sciences}

37. Sivvam, M. (2012). Female entrepreneurship: An Indian perspective. Saarbrücken, Germany: LAP Lambert.

38. South Africa History Online (SAHO). (1994). South African first democratic elections. http://www.sahistory.org.za/dated-event/south-africas-first-democratic- elections. Accessed: 2016/01/21.

39. South African History Online (SAHO). (2011). Pass laws in South Africa 1800- 1994. http://www.sahistory.org.za/south-africa-1806-1899/pass-laws-south-africa-

40. 1800-1994. Accessed: 2015/09/03.

41. SPSS - IBM Corporation. (2018). IBM SPSS Statistics for Windows (Version 25.0). Armonk, NY: IBM Corporation.

42. United Nations (UN). (2008). Female 2000 and beyond: Rural female in a changing world: Opportunities and challenges. Geneva: United Nations Publishers.

43. Veena, M. \& Nagaraja, N. (2013). Comparison of male and female entrepreneurs: An empirical study. International Journal of Engineering and Management Research, $3(6), 138-143$.

44. Verheul, I. \& Thurik, R. (2001). Start-up capital: Does gender matter? Small Business Economics, 16(4), 329-346.

45. Walker, E. \& Brown, A. (2004). What success factors are important to small business owners? International Small Business Journal, 22(6), 577-594.

46. Wiklund, J., Davidsson, P. \& Delmar, F. (2003). What do they think and feel about growth? An expectancy- value approach to small business managers' attitudes toward growth. Entrepreneurship Theory and Practice, 27(3), 247-270.

47. Wilde, E.T., Batchelder, L. \& Ellwood, D.T. (2010). The mommy track divides: The impact of childbearing on wages of women of differing skills levels. NBER Working Paper, 16582. 
Approved at the meeting of the editorial board International Symposium on Education, Psychology and Social Sciences Proceedings ISEPSS; September, 28 2019: OEAPS Inc.\& COREF University of Tokyo; Chief Editor Jamie Halsall. Tokyo, Japan : OEAPS Inc., 2019. -110 P. ISBN:9781707482818

Number layout 04.11.2019

Signed in print 07.11.2019

Published on 11.11.2019

The paper used in this publication meets the requirements of ANSI/NISO Z39.48-1992 (Permanence of Paper) 
MINISTERIO DE EDUCACIÓN, CULTURA Y DEPORTE

Subsecretaría

Subdirección General de Cooperación Internacional

Edita: @ SECRETARÍA GENERAL TÉCNICA

Subdirección General de Documentación y Publicaciones

Edición: 2019
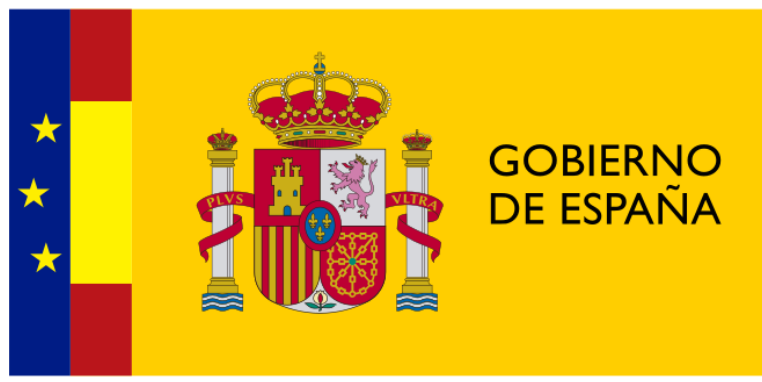

MINISTERIO

DE EDUCACIÓN, CULTURA

Y DEPORTE 
